\title{
Biometric variation among two Mangrove Warbler Setophaga petechia populations of Northwestern Mexico
}

\author{
Cheryl L. Schweizer \\ West Virginia University
}

Follow this and additional works at: https://researchrepository.wvu.edu/etd

\section{Recommended Citation}

Schweizer, Cheryl L., "Biometric variation among two Mangrove Warbler Setophaga petechia populations of Northwestern Mexico" (2012). Graduate Theses, Dissertations, and Problem Reports. 576.

https://researchrepository.wvu.edu/etd/576

This Thesis is protected by copyright and/or related rights. It has been brought to you by the The Research Repository @ WVU with permission from the rights-holder(s). You are free to use this Thesis in any way that is permitted by the copyright and related rights legislation that applies to your use. For other uses you must obtain permission from the rights-holder(s) directly, unless additional rights are indicated by a Creative Commons license in the record and/ or on the work itself. This Thesis has been accepted for inclusion in WVU Graduate Theses, Dissertations, and Problem Reports collection by an authorized administrator of The Research Repository @ WVU. For more information, please contact researchrepository@mail.wvu.edu. 


\title{
BIOMETRIC VARIATION AMONG TWO MANGROVE WARBLER SETOPHAGA PETECHIA POPULATIONS OF NORTHWESTERN MEXICO
}

\author{
Cheryl L. Schweizer
}

\author{
Thesis submitted to the \\ Davis College of Agriculture, Forestry, and Consumer Sciences \\ at West Virginia University \\ in partial fulfillment of the requirements for the degree of \\ Master of Science \\ in \\ Wildlife and Fisheries Resources
}

Robert C. Whitmore, Ph.D., Chair Philip Turk, Ph.D.

Petra Bohall Wood, Ph.D.

Division of Forestry and Natural Resources

Morgantown, West Virginia

2012

Keywords: biometrics, Mangrove Warbler, movement, Setophaga petechia, Yellow Warbler, morphology, Mexico 


\title{
ABSTRACT \\ BIOMETRIC VARIATION AMONG TWO MANGROVE WARBLER SETOPHAGA PETECHIA POPULATIONS OF NORTHWESTERN MEXICO
}

\section{CHERYL SCHWEIZER}

\begin{abstract}
Mangrove forests are one of the most productive ecosystems in the world. Despite this, over half of the world's mangroves have been lost, primarily due to anthropogenic activities. Northwestern Mexico is the northernmost range of mangroves in the eastern Pacific and western hemisphere. Mangrove Warblers (Setophaga petechia castaneiceps and S. p. rhizophorae), are small, tropical songbirds, endemic to these mangroves and are presumed to have sedentary lifestyles. Little is known about Mangrove Warblers across their range including basic life history data. Declining habitat across Mexico may be putting these populations at great risk. My primary objectives were to 1) define the biometric differences between and within the subspecies $S$. p. castaneiceps and S. p. rhizophorae and 2) determine local movement of a presumed sedentary mangrove bird.
\end{abstract}

In 2010-2011, I used playback and mist nets to capture, individually mark and measure 203 breeding adult Mangrove Warblers across their breeding ranges at 9 study areas in Baja California Sur and Sonora, Mexico. I summarized morphometric measurements using Principal Component Analysis (PCA) and performed Multivariate Analysis of Variance (MANOVA) to test if differences existed between subspecies, sex, and study areas. Results conclude $S . p$. castaneiceps is different from $S$. p. rhizophorae $(\mathrm{P}=<0.001)$, such that $S$. $p$. castaneiceps was a larger subspecies. Males were larger than females $(\mathrm{P}=<0.001)$ in both subspecies and variation existed among study areas in $S$. $p$. castaneiceps $(\mathrm{P}=0.001)$ and $S$. p. rhizophorae $(\mathrm{P}=<0.001)$. After finding significance among study areas, we then used SAS 9.2 to run MANOVA with posthoc contrasts for each morphometric measurement within a subspecies. We found the Pacific Coast populations of $S$. p. castaneiceps to be generally larger than the western coast Sea of Cortez populations. The northernmost population for $S$. $p$. rhizophorae was smaller overall compared to the other populations sampled in Sonora.

The S. p. castaneiceps banded population was re-sighted during wintering (2010) and breeding (2011) periods to examine localized, year-round movements. Waypoints of breeding (2010 and 2011) and wintering (2010) locations were mapped and analyzed using ArcMap 9.3.1 to determine localized movements within the population. Results suggest the Mangrove Warbler has limited, if any, year-round movements. No movement was found among mangrove stands, but territory switching was found to occur within a mangrove stand between the wintering and breeding season. There was high territory replacement among the entire population suggesting that there may be high occurrence of floaters. Re-sighting surveys and capture events were used to calculate density of males, females and pairs per mangrove site. There were no significant changes in population density between seasons $(\mathrm{P}=0.07)$, but males averaged a higher year-round density compared to females and pairs $(\mathrm{P}=0.02)$. 


\section{ACKNOWLEDGEMENTS}

I would like to thank my advisor, Dr. Robert Whitmore, for the opportunity to pursue a Master's of Science Degree and for all of his help, guidance, and knowledge throughout the

process. His kind heart and laughter gave me encouragement to overcome many topes. I would also like to thank my graduate committee, Dr. Petra Bohall Wood and Dr. Philip Turk, for all of their support and advice.

Thanks to Sophie Jacquier and Taryn Tuncer for all the fieldwork help, adventures, and memories. To John Burkhart, thanks for your hard work, commitment and patience with the statistics. Thanks to Dr. Eduardo Palacios and Dr. Horacio de la Cueva of CICESE for all their assistance in and out of the field, and Dr. Mike Strager for his GIS advice.

I would also like to acknowledge and thank my family supporting my choices, and lastly, thanks to Zach and Xena who never fail to brighten each day and make me smile.

Funding for this project was provided internally from Division of Forestry and Natural Resources at West Virginia University. 


\section{TABLE OF CONTENTS}

$\underline{\text { Page }}$

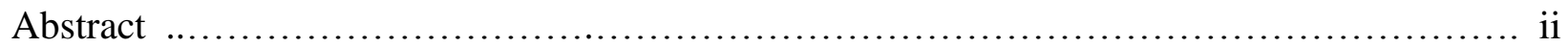

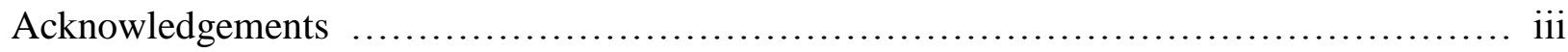

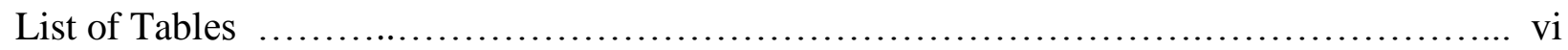

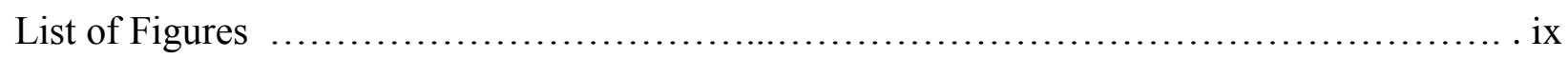

\section{Chapter I: Review of Literature Relevant to Study}

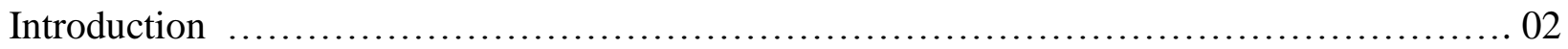

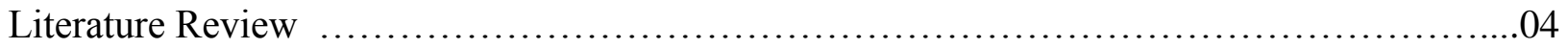

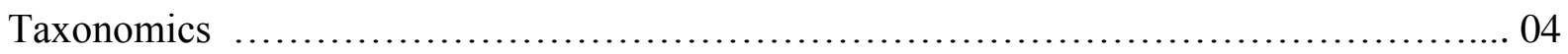

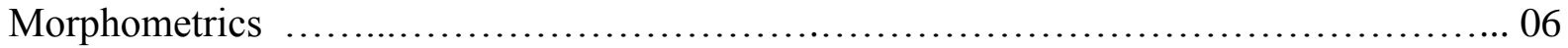

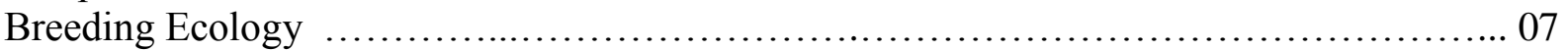

Mangroves of Northwestern Mexico ................................................... 08

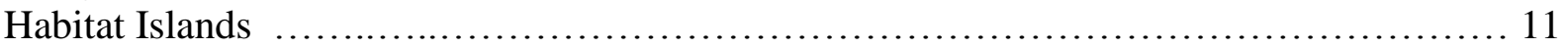

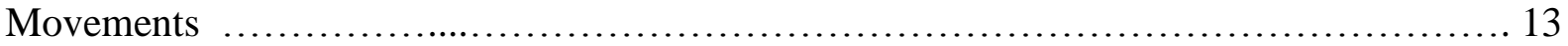

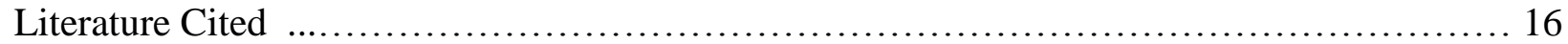

\section{Chapter II: Morphological Variation Between Mangrove Warbler Subspecies in Northwestern Mexico (Setophaga petechia castaneiceps and S. p. rhizophorae)}

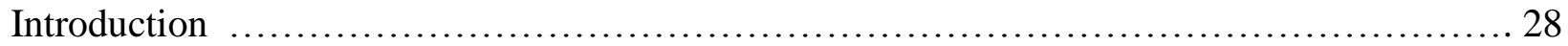

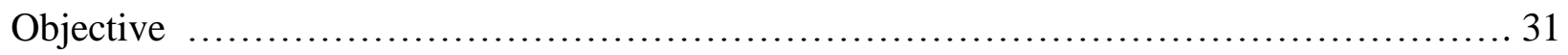

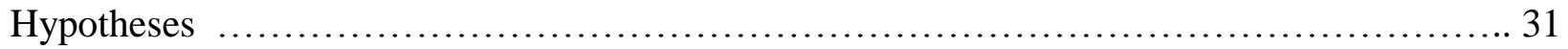

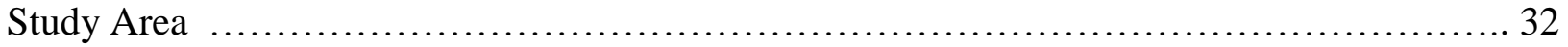

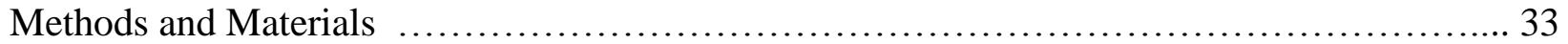

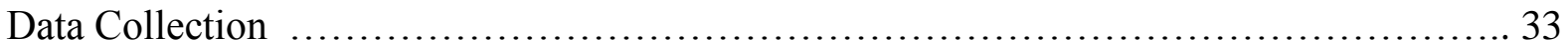

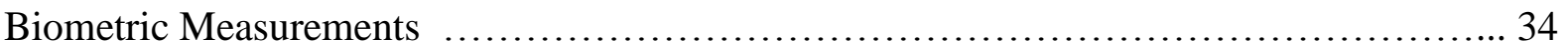

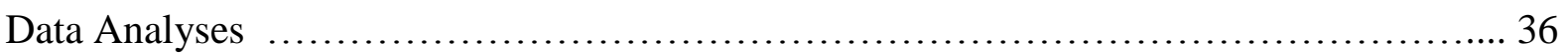

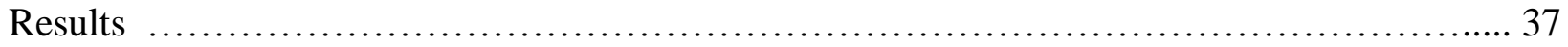

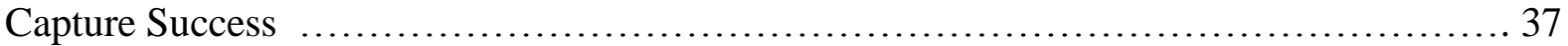

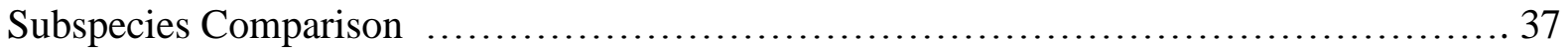

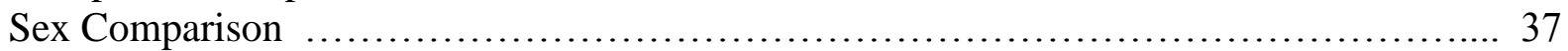

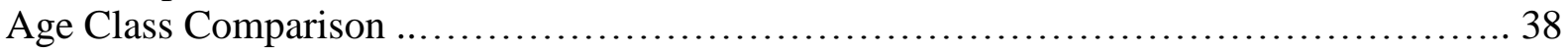

Variation Among Study Areas.......................................................... 38

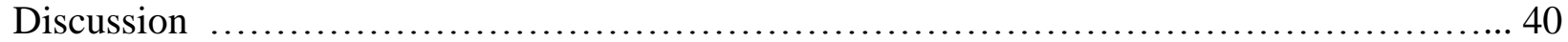

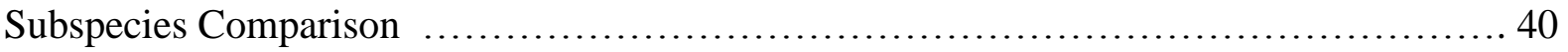

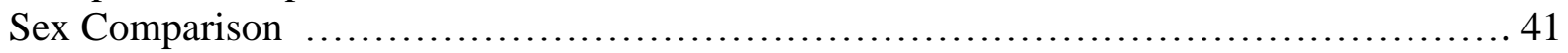

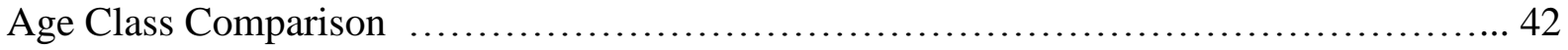




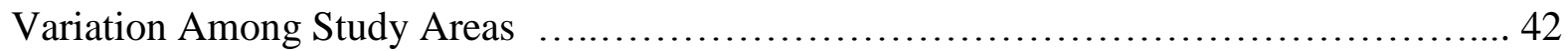

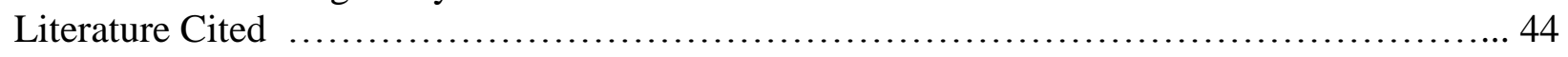

Chapter III: Year round movements of a Mangrove Warbler subspecies Setophaga petechia castaneiceps in Northwestern Mexico

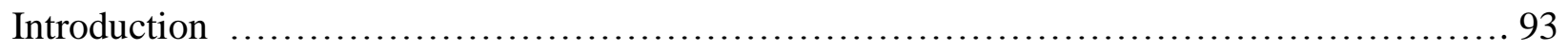

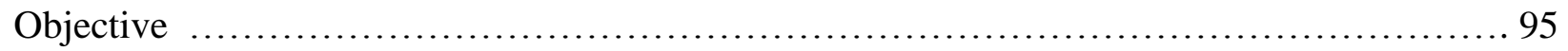

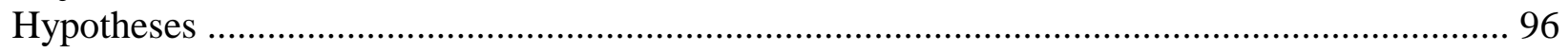

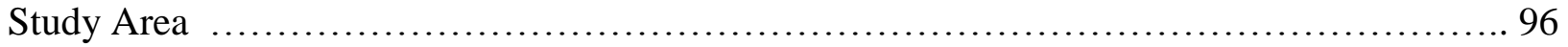

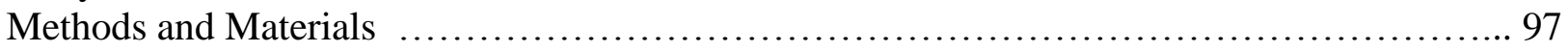

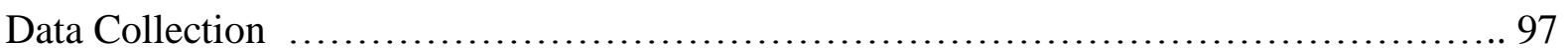

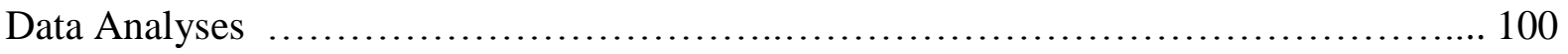

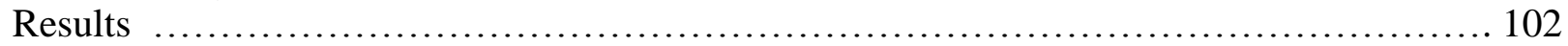

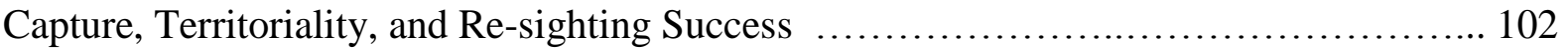

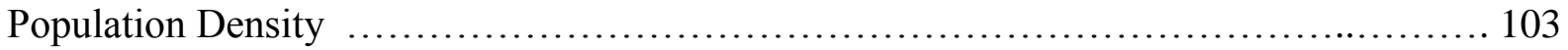

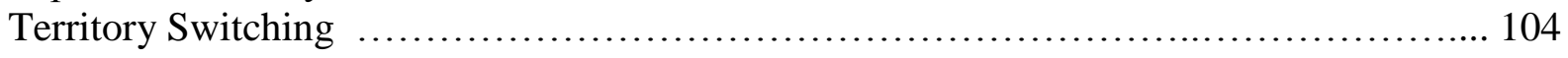

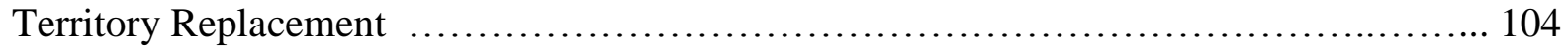

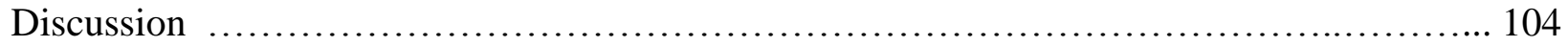

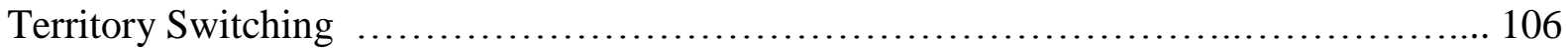

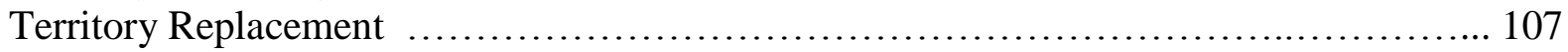

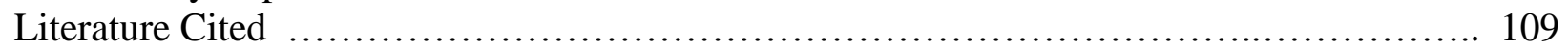




\section{LIST OF TABLES}

Chapter II: $\quad \underline{\text { Page }}$

Table 1. Area and perimeter of study areas and study sites in Baja California Sur and Sonora, Mexico. Straight-line distances (determined in ArcMap 9.3.1) between major study areas and minimum/maximum distances between study sites within a study area.

Table 2. MANOVA table comparing morphometric measurements among subspecies and sex (male and female) ....

Table 3. Summary of biometrics measurements on each subspecies separated by sex and age class. All measurements are averages in mm, except weight which is g. Standard deviation follows the averages $(\bar{x} \pm$ s.d).with range in parentheses below.

Table 4. Summary of variance explained by Principal Component Analysis (PCA) comparing biometrics of $S$. p. castaneiceps and S. p. rhizophorae.

Table 5. Factor loading (correlation coefficients between factors and variables) of the Principal Component Analysis (PCA) of the seven morphological traits used to evaluate the biometric variation between Mangrove Warblers. Only the first two principal components are shown..... 68

Table 6. MANOVA table comparing morphometric measurements among study areas within subspecies. S.p.c=Setophaga petechia castaneiceps, S.p.r= S. p. rhizophorae.

Table 7. ANOVA table comparing morphometric measurements among the five study areas (La Paz, Magdalena Bay, Puerto Adolfo López Mateos, Mulegé, and San Lucas) of S. p . castaneiceps in Baja California Sur, Mexico.

Table 8. ANOVA post-hoc contrasts comparing bill length measurements among study areas of S. p. castaneiceps. The mean bill length of one study area was compared to the mean bill length of all other study areas. 1= La Paz, 2= Magdalena Bay, 3= Mulegé, 4=San Lucas, 5= Puerto Adolfo López Mateos (PALM), 2, 5= Magdalena Bay and PALM combined.

Table 9. ANOVA post-hoc contrasts comparing tarsus length measurements among study areas of $S$. p . castaneiceps. The mean tarsus length of one study area was compared to the mean tarsus length of all other study areas. 1= La Paz, 2= Magdalena Bay, 3= Mulegé, 4=San Lucas, 5= Puerto Adolfo López Mateos (PALM), 2, 5= Magdalena Bay and PALM combined.

Table 10. ANOVA post-hoc contrasts comparing tail length measurements among study areas of $S$. p. castaneiceps. The mean tail length of one study area was compared to the mean tail length of all other study areas. 1= La Paz, 2= Magdalena Bay, 3= Mulegé, 4=San Lucas, 5= Puerto Adolfo López Mateos (PALM), 2, 5= Magdalena Bay and PALM combined. 
Table 11. ANOVA post-hoc contrasts comparing total length measurements among study areas of $S$. p. castaneiceps. The mean total length of one study area was compared to the mean total length of all other study areas. 1= La Paz, 2= Magdalena Bay, 3= Mulegé, 4=San Lucas, 5= Puerto Adolfo López Mateos (PALM), 2, 5= Magdalena Bay and PALM combined................ 77

Table 12. ANOVA post-hoc contrasts comparing weight measurements among study areas of $S$. p. castaneiceps. The mean weight of one study area was compared to the mean weight of all other study areas. 1= La Paz, 2= Magdalena Bay, 3= Mulegé, 4=San Lucas, 5= Puerto Adolfo López Mateos (PALM), 2, 5= Magdalena Bay and PALM combined.

Table 13. ANOVA table comparing morphometric measurements among the four study areas (Bahia Kino, Yavaros, San Carlos, and La Piedra) of S. p. rhizophorae in Sonora, Mexico....... 81

Table 14. ANOVA post-hoc contrasts comparing wing chord measurements among study areas of $S$. p. rhizophorae. The mean wing chord of one study area was compared to the mean wing chord of all other study areas. $1=$ San Carlos, 2= Bahia Kino, 3= La Piedra, 4=Yavaros........... 82

Table 15. ANOVA post-hoc contrasts comparing tarsus length measurements among study areas of $S$. $p$. rhizophorae. The mean tarsus length of one study area was compared to the mean tarsus length of all other study areas. 1= San Carlos, 2= Bahia Kino, 3= La Piedra, $4=$ Yavaros

Table 16. ANOVA post-hoc contrasts comparing tail length measurements among study areas of S. p. rhizophorae. The mean tail length of one study area was compared to the mean tail length of all other study areas. 1= San Carlos, 2= Bahia Kino, 3= La Piedra, 4=Yavaros.

Table 17. ANOVA post-hoc contrasts comparing total length measurements among study areas of $S$. p. rhizophorae. The mean total length of one study area was compared to the mean total length of all other study areas. 1= San Carlos, 2= Bahia Kino, 3= La Piedra, 4=Yavaros.

Table 18. ANOVA post-hoc contrasts comparing weight measurements among study areas of $S$. p. rhizophorae. The mean weight of one study area was compared to the mean weight of all other study areas. 1= San Carlos, 2= Bahia Kino, 3= La Piedra, 4=Yavaros.

\section{Chapter III:}

Table 1. Area and perimeter of study areas and study sites in BCS, MX. Straight-line distances between major study areas and minimum/maximum distances between study sites within a study area.

Table 2. Percent re-sights of male and female Mangrove Warblers during different periods by study area and study site. 
Table 3. Population density (\# of individuals/ha) of S. p. castaneiceps across study areas and study sites, Baja California Sur, Mexico

Table 4. Repeated measures ANOVA table (using Autoregressive 1 covariance structure) comparing population densities among sex (Male, Female, Pair), season (Breeding 2010, Wintering 2010, Breeding 2011), and the interaction of sex and season.

Table 5. Territory switching in banded territorial adults observed during both re-sighting periods. All distances are straight line between an individual's observed locations. Study site refers to individual mangrove within major study area (LP, La Paz; PALM; MU, Mulegé;

SL, San Lucas)

Table 6. Territory replacements of territorial, banded adults occurring within mangrove patches throughout the re-sighting periods. Territory vacancies refers to territories in which a previously territorial individual was not re-sighted. 


\section{LIST OF FIGURES}

\section{Chapter I: $\quad$ Page}

Figure 1. Mangrove warbler subspecies. Setophaga petechia castaneiceps male (top left), S. $p$. castaneiceps female (top right), S. p. rhizophorae male (bottom left),

S. p. rhizophorae (bottom right)

Figure 2. Breeding ranges of Setophaga petechia in the petechia and erithachorides subspecies groups: 1, castaneiceps; 2 , rhizophorae; 3, phillipsi; 4, xanthotera; 5, aithocorys; 6 , iguana; 7 , aequatorialis; 8 , jubaris; 9 , peruviana; 10 , aureola; 11 , oraria; 12 , rufivertex; 13 , bryanti; 14 , erithachorides; 15, gundlachi; 16, flaviceps; 17, eoa; 18, solaris; 19, chlora; 20, albicollis; 21, barthomelica; 22, melanoptera; 23, ruficapilla; 24, babad; 25, petechia; 26, alsiosa; 27 , rufopileata; 28, aurifroms; 29, obscura; 30, cienagae; 31, paraguanae; 32, chrysendeta; 33, flavida; 34, armouri (from Browning 1994) 26

\section{Chapter II:}

Figure 1. Distribution and study site locations of S. p. castaneiceps, Baja California Sur, Mexico, with details showing five major study areas (San Lucas, Mulegé, Puerto Adolfo López Mateos (PALM), Magdalena Bay, and La Paz) and study sites within the major study areas.... 50

Figure 2. Magdalena Bay study area, Baja California Sur, Mexico, from lagoon (A) and interior (B)

Figure 3. Mulegé study area, Baja California Sur, Mexico from coast (A) and showing common

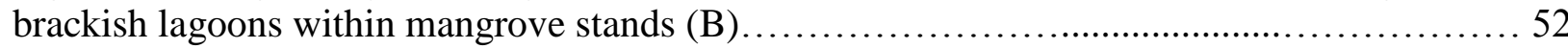

Figure 4. San Lucas study area, Baja California Sur, Mexico............................... 53

Figure 5. Puerto Adolfo López Mateos (PALM) study area, Baja California Sur, Mexico from

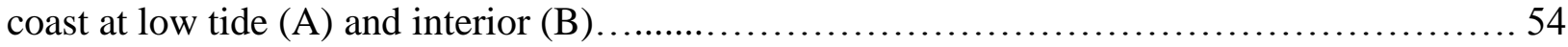

Figure 6. La Paz study area. Baja California Sur, Mexico from coast (A) and interior (B)........ 55

Figure 7. Distribution and study site locations of S. p. rhizophorae, Sonora, Mexico, with details showing four major study areas (Bahia Kino, San Carlos, La Piedra, and Yavaros) and study sites within the major study areas........................................ 56

Figure 8. San Carlos study area, Sonora, Mexico................................... 57

Figure 9. La Piedra study area, Sonora, Mexico from interior $(\mathrm{A})$ and coast $(\mathrm{B}) \ldots \ldots \ldots \ldots \ldots . \ldots 58$

Figure 10. Yavaros study area, Sonora, Mexico, from interior (A) and from coast (B)............ 59

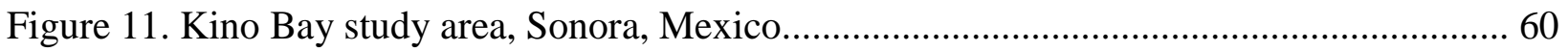


Figure 12. Individuals banded at each study area divided by age class (after second year, ASY; second year, SY). Individuals from La Paz, Magdalena Bay, Mulegé, San Lucas and Puerto Adolfo López Mateos (PALM) study areas belong to S. p. castaneiceps. Individuals from Bahia Kino, La Piedra, San Carlos and Yavaros study areas are S. p. rhizophorae. 63

Figure 13. Biplot of Principal Component Analysis (PCA) with 95\% confidence ellipses. 1 refers to $S$. p. castaneiceps and 2 refers to $S$. p. rhizophorae individuals.

Fig. 14. Boxplot of bill lengths (mm) of S. p. castaneiceps among study areas in Baja California Sur, Mexico. 1= La Paz, 2= Magdalena Bay, 3= Mulegé, 4=San Lucas, and 5= Puerto Adolfo López Mateos (PALM).

Fig. 15. Boxplot of tarsus lengths (mm) of $S$. p. castaneiceps among study areas in Baja California Sur, Mexico. 1= La Paz, 2= Magdalena Bay, 3= Mulegé, 4=San Lucas, and 5= Puerto Adolfo López Mateos (PALM).....

Fig. 16. Boxplot of tail lengths (mm) of S. p. castaneiceps among study areas in Baja California Sur, Mexico. 1= La Paz, 2= Magdalena Bay, 3= Mulegé, 4=San Lucas, and 5= Puerto Adolfo López Mateos (PALM).....

Fig. 17. Boxplot of total lengths (mm) of S. p. castaneiceps among study areas in Baja California Sur, Mexico. 1= La Paz, 2= Magdalena Bay, 3= Mulegé, 4=San Lucas, and 5= Puerto Adolfo

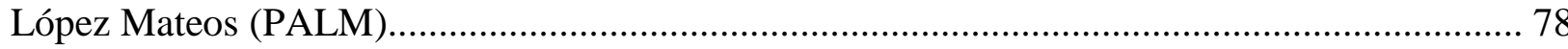

Fig. 18. Boxplot of weight (g) of S. p. castaneiceps among study areas in Baja California Sur, Mexico. 1= La Paz, 2= Magdalena Bay, 3= Mulegé, 4=San Lucas, and 5= Puerto Adolfo López Mateos (PALM.

Fig. 19. Boxplot of wing chord (mm) of S. p. rhizophorae among study areas in Sonora, Mexico. 1= San Carlos, 2= Bahia Kino, 3= La Piedra, 4= Yavaros. 83

Fig. 20. Boxplot of tarsus length (mm) of S. p. rhizophorae among study areas in Sonora, Mexico. 1= San Carlos, 2= Bahia Kino, 3= La Piedra, 4= Yavaros. 85

Fig. 21. Boxplot of tail length (mm) of S. p. rhizophorae among study areas in Sonora, Mexico. 1= San Carlos, 2= Bahia Kino, 3= La Piedra, 4= Yavaros.

Fig. 22. Boxplot of total length (mm) of S. p. rhizophorae among study areas in Sonora, Mexico. 1= San Carlos, 2= Bahia Kino, 3= La Piedra, 4= Yavaros. 89

Fig. 23. Boxplot of weight (g) of S. p. rhizophorae among study areas in Sonora, Mexico. 1= San Carlos, 2= Bahia Kino, 3= La Piedra, 4= Yavaros. 
Figure 1. Five major study areas (San Lucas, Mulegé, Puerto Adolfo López Mateos (PALM), Magdalena Bay, and La Paz) and study site locations in Baja California Sur, Mexico 113

Figure 2. Magdalena Bay study area, Baja California Sur, Mexico, from lagoon (A) and interior (B) 114

Figure 3. Mulegé study area, Baja California Sur, Mexico from coast (A) and showing common brackish lagoons within mangrove stands (B). 115

Figure 4. San Lucas study area, Baja California Sur, Mexico. 116

Figure 5. Puerto Adolfo López Mateos (PALM) study area, Baja California Sur, Mexico from coast at low tide (A) and interior (B).....

Figure 6. La Paz study area. Baja California Sur, Mexico from coast (A) and interior (B)....... 118

Figure 7. Number of individuals and pairs banded (2010) and re-sighted $(2010,2011)$ in the major study areas.

Figure 8. Boxplots of $S$. $p$. castaneiceps density (birds/ha) by sex ( $\mathrm{F}=$ female, $\mathrm{M}=$ male, $\mathrm{P}=$ pair) across the combined seasons of Breeding 2010, Wintering 2010 and Breeding 2011...........124

Figure 9. Boxplots of $S$. p. castaneiceps density (birds/ha) by season (B0= Breeding 2010, B1= Breeding 2011, and W=Wintering 2010) across the combined sexes of males, females and pairs. 


\section{CHAPTER I}

REVIEW OF LITERATURE RELEVANT TO STUDY 


\section{INTRODUCTION}

Mangroves are one of the three most productive ecosystems in the world along with coral reefs and rain forests (Holguin et al. 2006). The Gulf of California is the northern edge for the distribution of mangroves in the Eastern Pacific and western hemisphere (Whitmore et al. 2005; Ruiz-Luna et al. 2010). Despite low human density in this area, there is increasing pressure on mangrove stands from anthropogenic activities (e.g. shrimp farming, rice cultivation, and urban development) which has led to localized destruction and fragmentation (Páez-Osuna et al. 2003; Brusca 2004; Glenn et al. 2006).

The mangrove forest of Baja California Sur and Sonora, Mexico is a mosaic of small islands as a result of habitat fragmentation due to increased pressures from human activities. In fact, within twenty years (1972-92) 65\% of mangrove forests in Mexico were destroyed due to anthropogenic disturbance (Herrera-Silveira and Ceballos-Cambranis 2000), 70,000 ha lost between 1993 and 2000 (SEMARNAT 2003) (including 2,300 ha across Northwestern Mexico (early 1970's to 2005) (Ruiz-Luna et al. 2010)), and over 50\% of mangroves have been destroyed worldwide (Holguin et al. 2006). Furthermore, this region is affected by seasonal hurricanes which cause considerable damage on mangrove forests by reducing overall stem density and basal area and uprooting trees (Kovac et al. 2001). Not only are tropical depressions common, but 78\% of Mexico’s total of hurricanes occur here (Flores-Verdugo et al. 1992). These influences combined with these weakened mangrove stands (e.g. exhibiting homogeneous tree structure and diversity, gaps or breaks in continuous vegetation, and poor health from lack of microbial benthic communities) in this area, present a great concern to study these unique habitats and preserve their biodiversity. 
Few birds specialize in mangrove forests and detailed research of the ecology of the confined mangrove birds is sparse (Hogarth 1999; Luther and Greenberg 2009). The Mangrove Warbler (Setophaga petechia castaneiceps and Setophaga petechia rhizophorae, Fig 1.) is a small, tropical subspecies of the cosmopolitan Yellow Warbler (Setophaga petechia). It is a mangrove specialist and is endemic to the Pacific and Atlantic coasts of Mexico, Central and northern South America (Browning 1994). The nominate species, Yellow Warbler, is one of the most widespread of all warblers breeding from Alaska south to northwestern Peru (Curson et al. 1994). The generalization that temperate birds differ from tropical species in life-history traits, survivorship, and behavior is widely accepted. Despite these acceptances, foundational ecological data is absent for most tropical species.

The biometry of the Yellow Warbler has been well studied across its range (Wiedenfeld 1991), but only a few studies, consisting of limited samples on study skins, have been carried out on the Mangrove Warbler subspecies (S. p. spp.) in Mexico (Ridgeway 1885, 1902; Van Rossem 1935,1947). Often, variations in morphometric traits are coupled with variation in other morphological, physiological, and/or behavioral traits, both within and among species (Schluter and Smith 1986; Gustafsson 1988; Molina-Borja and Rodríguez-Domínguez 2004; Putnam and Flueck 2011). This variation in traits can influence survival and reproduction (Garland and Losos 1994; Rodriguero et al. 2002). Life-history of an individual can therefore be highly influenced by variation in morphometric traits. Biometric studies, in concurrence with other research, can be useful to further our understanding of the distribution and ecology of bird species and therefore improve conservation efforts (Atkinson et al. 1981; Telleria and Carbonell 1999; Campos et al. 2005). 
This thesis is organized into three chapters that will present and discuss biometric variation in Mangrove Warbler populations in two areas of Northwestern Mexico. The first chapter is a review of background literature relevant to the entire study. The second chapter focuses on morphometric variation between and among two Mangrove Warbler subspecies, S. $p$. castaneiceps and S. p. rhizophorae. The third chapter examines year-round movement in the $S$. p. castaneiceps population with implications to territorial systems and breeding strategy. These chapters are designated as individual chapters, and written and formatted for the specifications of The Auk, the quarterly journal of the American Ornithology Union.

\section{LITERATURE REVIEW}

\section{Taxonomics}

The Yellow Warbler (Setophaga petechia), a songbird within the wood warbler family Parulidae, order Passeriformes (Dunn and Garrett 1997), currently has 43 recognized subspecies (Browning 1994). Each of these subspecies fits into one of the three differentiated groups of the Yellow Warbler (American Ornithologist Union 1998): the aestiva group (Northern) which is migratory and breeds across North America, the petechia group (Golden) residing in the vicinity of the Caribbean Islands and West Indies, and the erithachorides group (Mangrove) found throughout mangroves on the Pacific and Atlantic coasts of Mexico, Central and northern South America (Browning 1994; Salgado-Ortiz et al. 2008; Fig. 2). Historically, each group was regarded as a distinct species with their names derived from the oldest described from each group; Motacilla aestiva (Gmelin 1789), Motacilla petechia (Linnaeus 1776) and Dendroica erithachorides (Baird 1858). 
Browning (1994) recognized 16 subspecies of Mangrove Warblers in the erithachorides group (Fig. 1). Adult male Mangrove Warblers (erithachorides group) differ from the northern aestevia group chiefly by their rufous/chestnut hood (Curson et al. 1994; Howell and Webb 1995; Dunn and Garrett 1997; Pyle 1997). Unlike the aestiva and petechia groups who use variable types of habitats (Lowther et al. 1999), birds of the erithachorides group are restricted to coastal mangroves, especially Red Mangrove (Rhizophora mangle) (Hogarth 1999) throughout their range (Curson et al. 1994).

The separation of the groups has always boggled taxonomists. In the early 1900's, the entire complex was known as “Golden Warblers” with no apparent groupings (Ridgeway 1902). The species was also lumped together in multiple ways such as combining the petechia and erithachorides group as one species (Golden Warbler) and aestiva group as another species (Yellow Warbler) (Hellmayr 1935), and combining Hellmayr's Golden Warbler with the Yellow Warbler (Aldrich 1942) which reflects upon the current taxonomy. In addition, Klein and Brown (1994) suggested the division of the species into two groups based on their phylogenic study of Yellow Warblers using mitochondrial DNA. Their findings are consistent with those of Hellmayer (1935); one group consisting of migratory forms from North America (aestiva group) and the other consisting of the sedentary Mangrove and 'Golden' Warblers from the tropics (erithachorides and petechia groups).

Mangrove Warblers have long belonged to the genus Dendroica. Recent changes (15 April 2011) to classification and nomenclature have resulted in the sinking of the genus Dendroica and lumping with other genera to the genus Setophaga (American Ornithologists' Union 2011). 


\section{Morphometrics}

Biometrics refers to any behavioral or physical characteristic that can be measured and statistically analyzed as a means for identifying or verifying an individual. Behavioral biometrics usually measure characteristics that are acquired naturally over a period of time. Some examples of behavioral biometrics include voice behavior such as songs in birds or whale calls and signature recognition in humans. Physical biometrics measures any physical characteristics of an individual. Usually these characteristics are related to the appearance of the body such as wing lengths of birds, fingerprints of humans, and color/pattern of hair. Analyzing DNA to obtain information about genetic makeup is a physical biometric.

The life-history traits of the northern migratory populations of Yellow Warblers have been extensively studied (e.g. Morse 1966; Lowther et al. 1999; Milot et al. 2000). The most recent literature describing physical biometrics of all Yellow Warbler subspecies is Browning (1994). The main purpose of his study was to evaluate geographic variation and to determine the morphological limits of the subspecies. The basis for his subspecies identification was from color and pattern of breeding plumages of adult males and females. Measurements were secondary in characterizing only a few subspecies. These specimens were study skins, some of which dated back to the 1800 's.

Browning (1994) examined 63 Mangrove Warbler study skins from Baja California collected by Ridgeway (1885) and Van Rossem (1947). He described D. p. castaneiceps subspecific characters as nearest rhizophorae but slightly greener above, and males with chestnut streaks less dense and narrower. He also noted that male castaneiceps have slightly longer tails than rhizophorae. Browning (1994) further evaluated D. p. rhizophorae based on eight specimens from the state of Sonora, Mexico collected by Van Rossem (1935). He concluded 
that this subspecies is slightly more yellow below than castaneiceps, and males have wider chestnut streaks and shorter tails.

Measurements for the erithachorides group were reported by Curson et al. (1994) from 16 male and seven female study skins. These measurements were taken from Ridgeway (1902), except for the wing lengths which were from Pyle et al. (1987). Male wing length was 53-70 $\mathrm{mm}$, tail length 45-52 mm, bill length $11 \mathrm{~mm}$, and tarsus 18-22 mm. Female wing length was 56-63 mm, tail length 45-47 mm, bill length $11 \mathrm{~mm}$, and tarsus 17-22 mm. These results reflected individuals from differing subspecies throughout Central and South America, Caribbean, and the Galápagos Islands.

Mangrove Warblers are very similar to Yellow Warblers but average slightly larger and have a more rounded wing shape (primary 9 is shorter than primary 6). Generally, Mangrove Warblers are greener above and do not have as much yellow edging on wings. Female and immature Mangrove Warblers commonly show chestnut patches on various parts of the crown, face and throat, but are closely related to the plumages of female and immature Yellow Warblers (Lowther et al. 1999).

\section{Breeding Ecology}

Sedentary tropical birds often lay small clutches and have long incubation, nestling, and fledgling dependency periods for both sexes (Klopfer et al. 1974). They also typically have longer breeding seasons (Ricklefs 1969a). It is common of tropical resident birds to actively defend feeding territories (Cox 1985; Greenberg and Gradwohl 1986), and unlike most migratory species, for females to engage in territorial singing (Thorpe 1972; Catchpole and Slater 1995). Tropical birds generally have low nesting success (Skutch 1966; Ricklefs 1969b) and high adult 
survivorship (Fogden, 1972; Greenberg and Gradwohl 1986, 1997; Francis et al. 1999). Annual survivorship rates for temperate zone passerines, for example, are about $40-60 \%$, whereas tropical birds are approximately 80\%-90\% (Ricklefs 1973).

Three studies examined the breeding ecology of Mangrove Warblers. Snow (1996) studied Mangrove Warbler subspecies in the Galápagos Islands (D. p. aureola), and Barrantes (1998) studied D. p. xanthotera in Costa Rica. For my study, I follow the timing of breeding events reported by Salgado-Ortiz et al. $(2008,2009)$ due to the location (latitude) of their study species being nearest to mine. They studied the breeding ecology of one Mangrove Warbler subspecies of the southeast coast (Yucatán Peninsula) Mexico, D. p. bryanti. Based on their findings, the breeding season spans three and a half months from mid-April to late-July. Territories average 0.77 ha in size and males defend territories year round. Density averages 10.6 pairs/10 ha and does not change between the breeding and non-breeding seasons. Nest building begins the second half of April and takes approximately five days. The average date of egg laying is May 18, with a full clutch consisting of 3 eggs. The number of nesting attempts is 1-5, averaging 1.8 per female. Nests were initiated as late as the end of July. The incubation period is 12-14 days with average date of hatching on 30 May. The nestling period is 11 days on average. The average date of fledging (for the first nest attempt) is 12 June. Fecundity declines and adult survival increases in Yellow Warblers from temperate to tropical environments (Salgado-Ortiz et al. 2008).

\section{Mangroves of Northwestern Mexico}

Mangroves (or mangals) are almost exclusively tropical (approximately between $30^{\circ} \mathrm{N}$ and $38^{\circ} \mathrm{S}$ ) and limited by low temperatures (Hogarth 1999; Stuart et al. 2007; Ruiz-Luna et al. 
2010). Mangroves are distributed below $26^{\circ} \mathrm{N}$ in the Gulf of Mexico up to $29^{\circ} 20^{\prime} \mathrm{N}$ in the Sea of Cortez, which is the northern edge of mangrove distribution in the Eastern Pacific and western hemisphere (Whitmore et al. 2005; Ruiz-Luna 2010). Mangroves in Northwestern Mexico border the coastline of the states of Nayarit, Sinaloa, Sonora, and Baja California Sur.

Three mangrove species occur in Northwestern Mexico, each belonging to a separate family; Black Mangrove (Avicennia germinans), White Mangrove (Laguncularia racemosa), and Red Mangrove (Rhizophora mangle) (Roberts 1989; Ruiz-Luna et al. 2010). Red mangrove is the most common mangrove found in Baja California (Roberts 1989). Mangroves in Northwestern Mexico rarely exceed $5 \mathrm{~m}$ in height (Felger et al. 2001). No consistent species distribution or assemblage is found throughout this area (Ruiz-Luna et al. 2010), however mangrove species generally occur along a seaward zonation of black mangrove in the shallowest water, white mangrove in the center of the stand, and red mangrove in the deepest water (Tomlinson 1986; Hogarth 1999; Felger et al. 2001).

Mangroves generally grow in an environment whose salinity is between that of fresh water and sea water (Hogarth 1999), but can grow and tolerate hypersaline water (Felger et al. 2001). They are adapted to being submerged in salt water and lack understory growth due to twice daily tidal cycles and periodic flooding events caused by seasonal storms. Resultantly, mangrove trees have developed various forms of aerial roots to obtain oxygen for respiration. Aerial roots of red mangrove diverge from the tree as much as $2 \mathrm{~m}$ above the ground (Hogarth 1999) which make it more flexible to live in water logged areas. Black and white mangroves exhibit a different root structure, such that they radiate shallow, horizontal roots underground equipped with vertical standing pneumatophores. The pneumatophores protrude from the mud 
(some as high as $3 \mathrm{~m}$ ) and are the main mechanism for gas exchange with underground tissue (Hogarth 1999).

Mangrove forests, and resultantly their inhabitants, may be subject to more disturbance than other forests due to their exposure to typhoons, coastal erosion, and fluctuating river discharges, for example (Hogarth 1999). Increase in destruction from anthropogenic pressures (such as shrimp farming, rice cultivation and urban development) has further heighted concern for mangroves in Mexico (Páez-Osuna et al. 2003; Brusca 2004; Glenn et al. 2006). Throughout the last few years, there have been numerous mangrove protection laws enacted and amended in Mexico. In 2003, mangrove management in Mexico was regulated by the Mexican Official Norm (NOM-022-SEMARNAT-2003) which "established the specifications for preservation, conservation, sustainable use and restoration of the coastal wetlands in mangrove areas" (SEMARAT 2003). This law allowed for the enforcement of mangrove protection, until the agreement to add Article 4.43 in 2004 which states "the prohibition of work and activities set out in paragraphs 4.4 and 4.22 and the limits set out in paragraphs 4.14 and 4.16 may be excluded if there is a preventative report of environmental impact statement, or if the case establishes compensation arrangements for the benefit of wetlands and it obtains corresponding land use change authorization" (Diario Oficial de la Federación, 3 Mayo de 2004). This addition gained immediate attention from many environmental organizations spurring for additional actions and reviews of the article. In 2007 another article was added (Article 60 TER of the Wildlife General Law), in which "it is forbidden to remove, fill, transplant, prune, or conduct any work or activity which directly or indirectly affects mangroves" (Diario Oficial de la Federación, 1 Febrero de 2007). Under this addition, Mexico prohibited nearly all urban development that was harmful to mangrove ecosystems. 


\section{Habitat Islands}

Islands can either be naturally occurring, such as oceanic or ponds, or can be created through landscape characteristics. Geographic barriers (vicariance) are a common cause of restricting interactions among/within populations (Fitzpatrick et al. 2009). Landscape features such as mountains, canyons, and water sources quickly set a boundary for a habitat patch and hinder migration. Habitat specialists, such as the Giant Conebill (Oreomanes fraseri) and Tawny Tit Spinetail (Leptasthenura yanacensis) of high-Andean Polylepis spp. forests, can be considered to live in islands due to their confinement to appropriate habitat (Cahill and Matthysen 2007).

Anthropogenic disturbance of continuously distributed populations also can lead to small and fragmented populations similar to the conditions of islands (Seppa and Laurila 1999; Andersen et al. 2004; Qie et al. 2011). Habitat fragmentation occurs when human land use alters natural landscapes leading to a reduction of total area (habitat loss), changes in patch configuration, and isolation of habitat remnants (Mitrovich et al. 2009; Richter 2009). Habitat fragmentation threatens the viability of populations (Saunders et al. 1991; Fahrig and Merriam 1994; Tilman et at. 1994; Burkey 1995; Groombridge and Jenkins 2002; Hanski 2011). Roads, houses, dams, and agricultural fields are all common examples of habitat fragmentation. As large areas of habitat are fragmented, the total habitat area is reduced and results in disjointed fragments of varying size (Smith 1990).

As populations become increasingly isolated on remnant habitat islands in areas of unsuitable habitat matrices (such as urban, suburban, and agricultural developments), they may not have any outside source populations for exchange of crucial information (e. g. genetic material and song types) (Cole 1981; Burkey 1995). Nature reserves can be considered habitat 
islands, such that they are often salvaged regions in vastly disrupted areas. Habitat fragmentation, advanced through anthropogenic interactions, is one of the greatest threats to biodiversity and conservation. Populations in fragmented habitat also have to cope with edge effect where ratio of edge relative to the interior habitat is heightened (Lidicker and Koenig 1996; Primack 2010).

The edge effect is an ecological process affecting habitat patches that resulted from fragmentation, and it is a result of interactions between two neighboring ecosystems that are disconnected by an abrupt transition (Murcia 1995). Three types of edge effects have a variety of influences on a habitat island relative to the species inhabiting the area: direct abiotic, direct biotic, and indirect biotic (Saunders et al. 1991)

Abiotic edge effects include microclimatic changes in the environment such as sunlight, temperature, humidity, wind, and fire (Prugh et al. 2008; Primack 2010). Road networks, for example, offer huge obstacles for birds, not only due to habitat loss and fragmentation required to build the roads, but also due to abiotic edge effects they introduce to an ecosystem (Kociolek et al. 2011). Introduction of pollutants, artificial and natural light, and noise are all results of roads. Artificial lighting can affect avian singing, breeding (Kempenaers et al. 2010), molting and migration (de Molenaar et al. 2006). Noise can reduce various bird population densities (Peris and Pescador 2004) and richness, change age structure (Francis et al. 2009), and alter acoustic communication (Wood and Yezerinac 2006; Goodwin and Shriver 2010; Luther and Baptista 2010). In forest habitats, abiotic factors can affect the interior of the habitat up to $50 \mathrm{~m}$ from the edge (Paton 1994). 
Direct biotic edge effects are often determined by the tolerance of the focal species. These effects involve any changes to species abundance and distribution due to the changes in overall conditions near the edge of the habitat patch.

Indirect biotic edge effects involve conditions changing species interactions, such as predation, parasitism, and competition. Stray dogs (Chokri and Selmi 2011), cats (Balogh et al 2011), and rats (Delgado et al. 2001), for example, all have been found to negatively impact nest success of numerous bird species. Predators, nest parasites, and exotic plants can encroach 500m or more, into the interior of a habitat patch (Wilcove 1985, Falk et al. 2011).

Two significant factors influencing edge effect are the movement behavior of matrix predators in the edge and their abundance in the matrix habitat (Vergara and Hahn 2009). For instance, the dynamics of bird populations are strongly affected by edge effect which enables matrix nest predators (Robinson et al. 1995; Hartley and Hunter 1998; Vergara and Hahn 2009). The Brown Headed Cowbird (Molothrus ater) is a species of great concern due to its increased brood parasitism facilitated by using habitat edges as an invasion point into habitat interiors. Additionally, predators can trigger an Allee effect (Gascoigne and Lipcius 2004) because predation rates tend to increase at low nest densities (Vergara and Hahn 2009).

\section{Movement}

The territoriality system of Mangrove Warblers is presumed to be much like other tropical resident species of birds, maintaining year-round territoriality with permanent pair bonds (Greenberg and Gradwohl 1986; Lefebvre et al. 1992; Morton and Stutchbury 2000). Territories often are co-defended and remain with constant boundaries regardless of high turn-over of individuals (Cox 1985; Greenberg and Gradwohl 1986, 1997; Gorrell et al. 2005). Mangrove 
Warblers usually tolerate migratory Yellow Warblers in their territories and direct most of their defense towards other Mangrove Warblers (Wiedenfeld 1992). In habitats with stable population density and year-long territorial birds, it is common that vacant territories are filled within a matter of hours (Greenberg and Gradwohl 1997; Morton et al. 2000; Fedy and Stutchbury 2004).

Territorial adults abandoning their territory and shifting to control neighboring established territories, hereafter territory switching, occurs in tropical resident birds, some more often depending on species. Greenberg and Gradwohl (1997) found territory switching to occur in $37 \%$ of their marked population of Checker-throated Antwrens, whereas Freed (1987) found movements were rare in adult tropical House Wrens with an established territory. Morton et al. (2000) proposed that territory switching may be driven by resource availability in neighboring territories.

A subspecies of Mangrove Warbler occurring in the Yucatán peninsula, Mexico, (Dendroica petechia bryanti), defends territories year round, forms permanent pair bonds, and maintains a stable population density year-round (Curson et al. 1994; Salgado-Ortiz et al. 2008). Density of this subspecies averaged 10.6 pairs/10 ha with territories having a mean size of 0.77ha and did not change between breeding and non-breeding season (Salgado-Ortiz et al. 2008). To my knowledge, no data confirming territory switching has been reported for Mangrove Warblers throughout their range.

Numerous methods are used to study movements and territorial systems in wildlife. Perhaps the most common method for studying movement in birds is through the use of color bands for individual identification. Many researchers have used color-marking and subsequent re-sighting to determine movement, territoriality and survivorship in populations. Greenberg and Gradwohl (1986), for example, re-sighted four species of color-marked antbirds (Myrmotherula 
fulviventris, Myrmotherula axillaris, Microrhopias quixensis, and Thamnophilus punctatus), and put the locations on a grid system to quantify movement within a territory and among years. Morton and Stuchbury (2000) color-marked Dusky Antbirds (Cercomacra tyrannina) and used playback in various locations to determine territory boundaries. Hestbeck et al. (1991) studied movements to previous and new wintering locations in Canada Geese (Branta canadensis) from large scale capture-resighting data. In my study, I will be using color-marking of individuals to focus on localized movement within the S. p. castaneiceps populations. 


\section{LITERATURE CITED}

ALDRICH, J. W. 1942. Specific relationships of the Golden and Yellow Warblers. Auk 59:447449.

AMERICAN ORNITHOLOGISTS' UniON. 1998. Check-list of North American Birds, 7th ed. American Ornithologists' Union, Washington, D.C.

AMERICAN ORNithologists' Union. 2011. Fifty-second supplement to the American Ornithologists' Union Check-list of North American Birds. Auk 128:600-613.

ANDERSEN, L. W., K. FoG, AND C. DAMGAARD. 2004. Habitat fragmentation causes bottlenecks and inbreeding in the European tree frog Hyla arborea. Proceedings of the Royal Society of London B 271:1293-1302.

AtKinson, N. K., R. W. Summers, M. Nicoll, And J. J. D. GreenwoOd. 1981. Population, movements and biometrics of the Purple Sandpiper Calidris maritima in Eastern Scotland. Ornis Scandinavica 12:18-27.

BAIRD, S. F. 1858. Birds. Pages 282-283 in Explorations and surveys to ascertain the most practical and economical route for a railroad from the Mississippi River to the Pacific Ocean, Vol. IX, Part II. Washington.

Balough, A. L., T. B. Ryder, AND P. P. MARRA. 2011. Population demography of Gray Catbirds in the suburban matrix: sources, sinks and domestic cats. Journal of Ornithology $152: 717-726$.

BARRANTES, G. 1998. Biología y comportamiento de Dendroica petechia xanthotera (Aves: Parulidae). Brenesia 49-50:61-69.

Browning, M. R. 1994. A taxonomic review of Dendroica petechia. Proceedings of Biological Sciences Washington 107:27-51.

BRUSCA, R. C. 2004. The Gulf of California-an overview. in Seashore Guide to the Northern Gulf of California. Arizona-Sonora Desert Museum, Tucson, AZ.

BURKEY, T.V. 1995. Extinction rates in Archipelagoes: Implications for Populations in Fragmented Habitats. Conservation Biology 9:527-541.

CAhill, J., AND E. MATThySEN. 2007. Habitat use by two specialist birds in high-Andean Polylepis forests. Biological Conservation 140:62-69. 
Campos, F., F. Gutiérrez-Corchero, M. A. Hernández, J. M. Rivas, And J. López-Fidalgo. 2005. Biometric differences among the Dipper Cinclus cinclus populations of Spain. Acta Ornithologica 40:87-93.

CAtchPole, C.K., AND P. J. B. Slater. 1995. Bird song: biological themes and variations. Cambridge University Press, Cambridge.

CHOKRI, M. A. AND S. Selmi. 2011. Predation of Pied Avocet Recurvirostra avosetta nests in a salina habitat:evidence for an edge effect. Bird Study 58:171-177.

CoLE, B.J. 1981. Colonizing abilities, island size, and the number of species on archipelagoes. American Nauralist 117:629-638.

Cox, G. W. 1985. The evolution of avian migration systems between temperate and tropical regions of the New World. American Naturalist 126:451-474.

Curson, J., D. Quinn, And D. BeAdle. 1994. New World Warblers. A \& C Black, London.

De MolenaAr, J. G., M. E. SAnders, And D. A. JonKers. 2006. Road lighting and grassland birds:local influence of road lighting on Black-tailed Godwit populations. Pages 114-136 in Ecological Consequences of Artificial Night Lighting (C. Rich and T. Longcore, Eds.). Island Press, Washington, D. C.

DECRETO POR EL QUE SE ADICIONA UN ARTÍCULO 60 TER Y SE ADICIONA UN SEGUNDO PÁRRAFO, ARTÍ́CULO 99, TODOS ELLOS DE LA LEY GENERAL DE VIDA SILVESTRE [Decree addition of section 60B and adding a second paragraph to Article 99, all from the Wildlife Act], Diario Oficial de la Federación, [D. O.], 1 Febrero de 2007 (Mex.).

Delgado, J. D., Arévalo, J. M. Fernández-Palacios. 2001. Road and topography effects on invasion: edge effects in rat foraging patterns in two oceanic island forests (Tenerife, Canary Islands). Ecography 24:539-546.

DIARIO OFICIAL ACUERDO QUE ADICIONA LA ESPECIFICACIÓN 4.43 A LA NOM-022-SEMARNAT2003, QUE ESTABLECE LAS ESPECIFICACIONES PARA LA PRESERVACIÓN, CONSERVACIÓN, APROVECHAMIENTO SUSTENTABLE Y RESTAURACIÓN DE LOS HUMEDALES COSTEROS EN ZONAS DE MANGLAR [Aggreement specifying additional 4.43 to NOM-022-SEMARNAT2003, which sets the specifications for the preservation, conservation, sustainable use and restoration of coastal wetlands in mangrove areas], Diario Oficial de la Federación, [D. O.], 3Mayo de 2004 (Mex.).

DunN, J. L., AND K. L. GARretT. 1997. A Field Guide to Warblers of North America. Houghton Mifflin, Boston.

FAHRIG, L., AND G. MERRIAM. 1994. Conservation of fragmented populations. Conservation Biology 8:50-59. 
FALK, K. J., E. NOL, AND D. M. BURKE. 2011. Weak effect of edges on avian nesting success in fragmented and forested landscapes in Ontario, Canada. Landscape Ecology 26:239-251.

FEDY, B. C. AND B. J. M. STUTChBURY. 2004. Territory switching and floating in White-bellied Antbird (Myrmeciza longipes), a resident tropical passerine in Panama. The Auk 12:486496.

Felger, R. S., M. B. Johnson, AND M. F. Wilson. 2001. The trees of Sonora, Mexico. Oxford University Press, New York.

FitZPATRICK, B. M., J. A. FordyCE, AND S. GAVRILETS. 2009. Pattern, process and geographic modes in speciation. Evolutionary Biology 22:2342-2347.

Flores-Verdugo, F., GonZÁlez-Farías, F., ZAMORANo, D.S. ANd RAMíREZ-GarCÍA, P. 1992. Mangrove ecosystems of the Pacific coast of Mexico: distribution, structure, litterfall, and detritus dynamics. Pages 269-288 in Coastal Plant Communities of Latin America (U. Seeliger, Ed.). Academic Press, California.

FogDEN, M. P. L. 1972. The seasonality and population dynamics of equatorial forest birds in Sarawak. Ibis 114:307-343.

Francis, C. D., C. P. ORTEGA, AND A. CRUZ. 2009. Noise pollution changes avian communities and species interactions. Current Biology 19:1415-1419.

FranCIS, C. M., J. S. TERBORGH, AND J. W. FITZPATRICK. 1999. Survival rates of understory forest birds in Peru. Pages 326-335 in Proceedings 22nd International Ornithological Congress, Durban. BirdLife South Africa, Johannesburg.

FREED, L. A. 1987. The long-term pair bond of a tropical house wren: advantage or constraint? American Naturalist 130:507-525.

GARLAND, T., AND J. B. LOSOS. 1994. Ecological morphology of locomotor performance in squamate reptiles. Pages 240-302 in Ecological Morphology: Integrative Organismal Biology (P. C. Wainwright and S. M. Reily, Eds.). University of Chicago Press, Chicago.

GASCOIGNE, J.C. AND R.N. LiPCIUS. 2004. Allee effects driven by predation. Journal of Applied Ecology 41:801-810.

Glenn, E. P., P. L. NAgler, R. C. BrusCA, ANd O. Hinojosa-HueRTA. 2006. Coastal wetlands of the northern Gulf of California: inventory and conservation status. Aquatic Conservation 16:5-28.

Gmelin, J. F. 1789. Caroli a Linné Systema Naturae. Vol. 1, Part 2. Pp 996. Lipsiae. 
GorRell, J. V., G. Ritchison, AND E. S. MORTON. 2005. Territory size and stability in a sedentary neotropical passerine: is resource partitioning a necessary condition? Journal of Field Ornithology 76:395-401.

GREENBERG, R., AND J.GRADWOHL. 1986. Constant density and stable territoriality in some tropical insectivorous birds. Oecologia 69:618-625

GREENBERG, R. AND J. GRADWOHL. 1997. Territoriality, adult survival, and dispersal in the Checker-throated Antwren in Panama. Journal of Avian Biology 28:103-110.

GROOMBRIDGE, B. AND M. JENKINS. 2002. World atlas of biodiversity: earth's living resources in the $21^{\text {st }}$ century. University of California Press, Berkeley.

GUSTAFSSON, L. 1988. Foraging behavior of individual coal tits, Parus ater, in relation to their age, sex, and morphology. Animal Behaviour 36:696-704.

HANSKI, I. 2011. Habitat loss, the dynamics of biodiversity, and a perspective on conservation. Journal of the Human Environment 40: 248-255.

HARTLEY, M.J. AND M.L. HuNTER. 1998. A meta-analysis of forest cover, edge effect, and artificial nest predation rates. Conservation Biology 12:465-469.

Hellmayr, C. E. 1935. Catalogue of birds of the Americas and the adjacent islands. Pages 363385 in Field Museum of Natural History. No. 13, Part VIII. Field Museum Press, Chicago.

Herrera-Silveira, J., AND E. Ceballos-CAmbranis. 2000. Manglares: ecosistemas valiosos. Biodiversitas 19:1-10.

HestBeCK, J. B., J. D. NichOLS, AND R. A. MALECKI. 1991. Estimates of movement and site fidelity using mark-resight data of wintering Canada Geese. Ecology 72:523-533.

Hogarth, P. J. 1999. The Biology of Mangroves. Oxford University Press, New York.

Holguin, G., P. Gonzalez-Zamorano, L. E. De-Bashan, R. Mendoza, E. Amador, And Y. BASHAN. 2006. Mangrove health in an arid environment encroached by urban development- a case study. Science of the Total Environment 63:260-274.

Howell, S. N. G., AND S. WeBB. 1995. A Guide to the Birds of Mexico and Northern Central America. Oxford University Press, New York.

Kempenaers, B., P. Borgstrom, P. Loes, E. Schlicht, And M. Valcu. 2010. Artificial night lighting affects dawn song, extra-pair siring success and lay date in songbirds. Current Biology 19:1735-1739. 
KLEIN, N. K., AND W. M. BROWN. 1994. Intraspecific molecular phylogeny in the Yellow Warbler (Dendroica petechia), and implications for avian biogeography in the West Indies. Evolution, 48:1914-1932.

Klopfer, P. H., D. I. Rubenstein, R. S. Ridgely, And R. J. BARnetT. 1974. Migration and species diversity in the tropics. Proceedings of the National Academy of Sciences USA 71:339-340.

Kociolek, A. V., A. P. Clevenger, C. C. St. Clair, and D. S. Proppe. 2011. Effects of road networks on bird population. Conservation Biology 25:241-249.

Kovac, J. M., M. Blanco-Correa, And F. Flores-Verdugo. 2001. A logistical regression model of hurricane impacts in a mangrove forest of the Mexican Pacific. Journal of Coastal Research 17:30-37.

LefebVRe, G., B. Poulin, AND R. MCNeIL. 1992. Settlement period and function of long-term territory in tropical mangrove passerines. The Condor 94:83-92.

LIDICKER, W. Z., AND W. D. KOENIG. 1996. Responses of terrestrial vertebrates to habitat edges and corridors. Pages 85-109 in Metapopulations and wildlife conservation. (D. R. McCullough, Ed.). Island Press, Washington, D.C.

LINNAEUS, C. 1766. Systema naturæ per regna tria naturæ, secundum classes, ordines, genera, species, cum characteribus, differentiis, synonymis, locis.. Edition 12, Part 1. Pp 334. Holmiæ.

Lowther, P. E., C. Celada, N. K. Klein, C. C. Rimmer, and D. A. Spector. 1999. Yellow Warbler (Dendroica petechia). in The Birds of North America, No. 454 (A. Poole and F. Gill, Eds.). The Birds of North America, Inc. Philadelphia, PA.

Luther, D. A., AND R. GreEnBERG. 2009. Mangroves: A global perspective on the evolution and conservation of their terrestrial vertebrates. BioScience 59:602-612.

LUTHER, D. AND L. BAPTISTA. 2010. Urban noise and the cultural evolution of birds. Proceedings of the Royal Society B 277:469-473.

Milot, E., H. L. GibBS, AND K. A. HobSON. 2000. Phylogeography and genetic structure of northern populations of the yellow warbler (Dendroica petechia). Molecular Ecology 9:667-681.

MitRovich, M.J., J.E. DifFEndORFER, AND R.N. FiSHER. 2009. Behavioral response of the coachwhip (Masticophie flagellum) to habitat fragment size and isolation in an urban landscape. Journal of Herpetology 43:646-656. 
MolinA-Borja, M., AND M. A. RodríGueZ-Domínguez. 2004. Evolution of biometric and lifehistory traits in lizards (Gallotia) from the Canary Islands. Journal of Zoological Systematics and Evolutionary Research 42:44-53.

MoRsE, D. H. 1966. The context of songs in the Yellow Warbler. Wilson Bulletin 78:444-455.

Morton, E. S., AND B. J. M. STUTChBURY. 2000. Demography and reproductive success in the dusky antbird, a sedentary tropical passerine. Journal of Field Ornithology 71:493-500.

Morton, E. S., K. C. Derrickson, AND B. J. M. Stutchbury. 2000. Territory switching behavior in a sedentary tropical passerine, the dusky antbird (Cercomarcra tyrannina). Behavorial Ecology 11:648-653.

MURICA, C. 1995. Edge effects in fragmented forests: implications for conservation. Trends in Ecology and Evolution 10: 58-62.

PATON, P. W. 1994. The effect of edge on avian nest success: how strong is the evidence? Conservation Biology 8:17-26.

Páez-Osuna, O., A. Gracia, F. Flores-Verdugo, L. P. Lyle-Fritch, R. Alonso-Rodríguez, A. RoQUe, AND A. C. RuIZ-FERnÁNDEZ. 2003. Shrimp aquaculture development and the environment in the Gulf of California ecoregion. Marine Pollution Bulletin 46:806-815.

PERIS, S. J. AND M. PESCADOR. 2004. Effects of traffic noise on passerine populations in Mediterranean wooded pastures. Applied Acoustics 65:357-366.

PRIMACK, RICHARD B. 2010. Essentials of Conservation Biology. Sinauer Associates, Massachusetts.

Prugh, L., K.E. Hodges, A.R.E Sinclair, AND J.S. Brashares. 2008. Effect of habitat area and isolation on fragmented animal populations. Proceedings of the National Academy of Sciences 105:20770-20775.

PutNAM, R. AND W. T. FLUECK. 2011. Intraspecific variation in biology and ecology of deer: magnitude and causation. Animal Production Science 51:277-291.

Pyle, P., S. N. G. Howell, R. P. Yunick, AND D. F. DeSAnTE. 1987. Identification Guide to North American Passerines. Slate Creek Press, California.

PYLE, P. 1997. Identification Guide to North American Birds, Part I. Slate Creek Press, California.

QIE, L., T. M. LEE, N. S. SoDHI, AND S. L. H. LIM. 2011. Dung beetle assemblages on tropical land-bridge islands: small island effect and vulnerable species. Journal of Biogeography 38:792-804. 
Richter, S.C., B.I. CROTHER, AND R.E. BROUGHTON. 2009. Genetic consequences of population reduction and geographic isolation in the critically endangered frog, Rana sevosa. Copeia 4:799-806.

RICKLEFS, R. E. 1969A. The nesting cycle of songbirds in tropical and temperate regions. Living Bird 8:165-175.

RICKLEFS, R. E. 1969B. An analysis of nesting mortality in birds. Smithsonian Contributions to Zoology 9:1-48.

RICKLEFS, R. E. 1973. Fecundity, mortality, and avian demography. Pages 366-435 in Breeding biology of birds. (D. S. Farner, Ed.). National Academy of Sciences, Washington D.C.

RIDGEWAY, R. 1885. A Review of the American "Golden Warblers". Proceedings of the United States National Museum 8:348-350.

RIDGEWAY, R. 1902. The birds of North and Middle America: A descriptive catalogue of the higher groups, genera, species, and subspecies of birds known to occur in North America, from the Arctic Lands to the Isthmus of Panama, the West Indies and other islands of the Caribbean Sea, and the Galapagos Archipelago. Pages 530-531 in Bulletin of the United States National Museum, No. 50, Part II. Washington: Government Printing Office.

Robinson, S.K., F.R. Thompson, T.M. DonOVAn, D.R. WhiteheAd, AND J. FAABORG. 1995. Regional forest fragmentation and the nesting success of migratory birds. Science 267:1987-1990.

Rodriguero, M. S., J. C. Vilardi, M. T. Vera, J. P. CAyOl, And E. Rial. 2002. Morphometric traits and sexual selection in Medfly (Diptera: Tephritidae) under field cage conditions. Florida Entomologist 85:143-149.

Ruiz-Luna, A., A. Cervantes Escobar, And C. Berlanga-Robles. 2010. Assessing distribution patterns, extent, and current condition of Northwest Mexico mangroves. Wetlands 30:717-723.

Salgado-Ortiz, J., P. P. Marra, T. S. Sillett, And R. J. Robertson. 2008. Breeding ecology of the mangrove warbler (Dendroica petechia bryanti) and comparative life history of the yellow warbler subspecies complex. Auk 125:402-410.

SAlgado-Ortiz, J., P. P. MARRA, AND R. J. Robertson. 2009. Breeding seasonality of the mangrove warbler (Dendroica petechia bryanti) from southern Mexico. Ornitologia Neotropical 20:255-263.

SAunders, D. A., R. J. HobBS, AND C. R. MARgules. 1991. Biological consequences of ecosystem fragmentation: a review. Conservation Biology 5:18-32. 
SCHLUTER, D., AND J. N. M. SMITH. 1986. Natural selection on beak and body size in the Song Sparrow. Evolution 40:221-231.

SECRETARia de Medio Ambiente y Recursos NATURALES. NORMA Oficial MeXiCANA NOM-022-SEMARNAT-2003, QUE ESTABLECE LAS ESPECIFICACIONES PARA LA PRESERVACIÓN, CONSERVACIÓN, APROVECHAMIENTO SUSTENTABLE Y RESTAURACIÓN DE LOS HUMEDALES COSTEROS EN ZONAS DE MANGLAR [Ministry of environment and natural resources. Mexican official standard NOM-022-SEMARNAT-2003, establishing the specifications for the preservation, conservation, development and restoration of coastal wetlands in mangrove areas], Diario Official de la Federación, [D.O.], 10 Abril de 2003 (Mex.).

SEPPA , P., AND A. LAURILA. 1999. Genetic structure of island populations of the anurans Rana temporaria and Bufo bufo. Heredity 82:309-317.

SKUTCH, A. F. 1966. A breeding bird census and nesting success in Central America. Ibis 108:116.

SMITH, R. L. 1990. Ecology and field biology. $4^{\text {th }}$ ed. Harper and Row, New York.

SNOw, D. W. 1966. Annual cycle of the Yellow Warbler in the Galapagos. Bird-Banding 37:4449.

Stuart, S. A., B. ChoAt, K. C. Martin, N. M. Holbrook, And M. C. Ball. 2007. The role of freezing in setting the latitudinal limits of mangrove forests. New Phytologist 173:576583.

Telleria, J. L., AND R. CARBOnELl. 1999. Morphometric variation of five Blackcap Slyvia atricapilla populations. Journal of Avian Biology 30:63-71.

THORPE, W. H. 1972. Duetting and antiphonal song in birds: its extent and significance. Behavior (Supplement) 18:1-197.

Tilman, D., MAy, R., Lehman, C. AND NowaK, M. 1994. Habitat destruction and the extinction debt. Nature 371: 65-66.

Tomlinson, P. B. 1986. The Botany of Mangroves. Cambridge University Press, New York.

VAn Rossem, A. J. 1935. The Mangrove warbler of Northwestern Mexico. San Diego Society of Natural History 8:67-68.

VAn Rossem, A. J. 1947. An undescribed race of the mangrove warbler from Baja California, Mexico. Transactions of the San Diego Society of Natural History 11:49-52.

VERGARA, P.M. AND I. HAHN. 2009. Linking edge effects and patch size effects: Importance of matrix nest predators. Ecological Modeling 220:1189-1196. 
WhitMore, R. C., R. C. BrusCa, J. L. L. De La LuZ, P. GonZÁLeZ-Zamorano, R. MENDOZASalgado, E. S. Amador-Silva, G. Holguin, F. Galván-Magana, P. A. Hastings, J. E. CARTROn, R. S. FELger, J. A. SEMINOFF, AND C. C. MCIVOR. 2005. The ecological importance of mangroves in Baja California Sur: conservation implications for an endangered ecosystem. Pages 298-333 in Biodiversity, Ecosystems, and Conservation in Northern Mexico. (J. E. Cartron, G. Ceballos, and F. S. Felger, Eds.). Oxford University Press, New York.

WIEDENFELD, D. A. 1991. Geographical morphology of male yellow warblers. Condor 93:712723.

WIEDENFELD, D. A. 1992. Foraging in temperate and tropical breeding and wintering Yellow Warblers. Pages 321-329 in Ecology and conservation of Neotropical migrant landbirds. (Hagan III, J. and D. Johnston, Eds.) Smithson. Institute Press, Washington, D.C.

WILCOVE, D. S. 1985. Nest predation in forest tracts and the decline of migratory songbirds. Ecology 66: 1211-1214.

WOOD, W.E. AND S. M. YEZERINAC. 2006. Song sparrow (Melospiza melocia) song varies with urban noise. The Auk 123:650-659. 


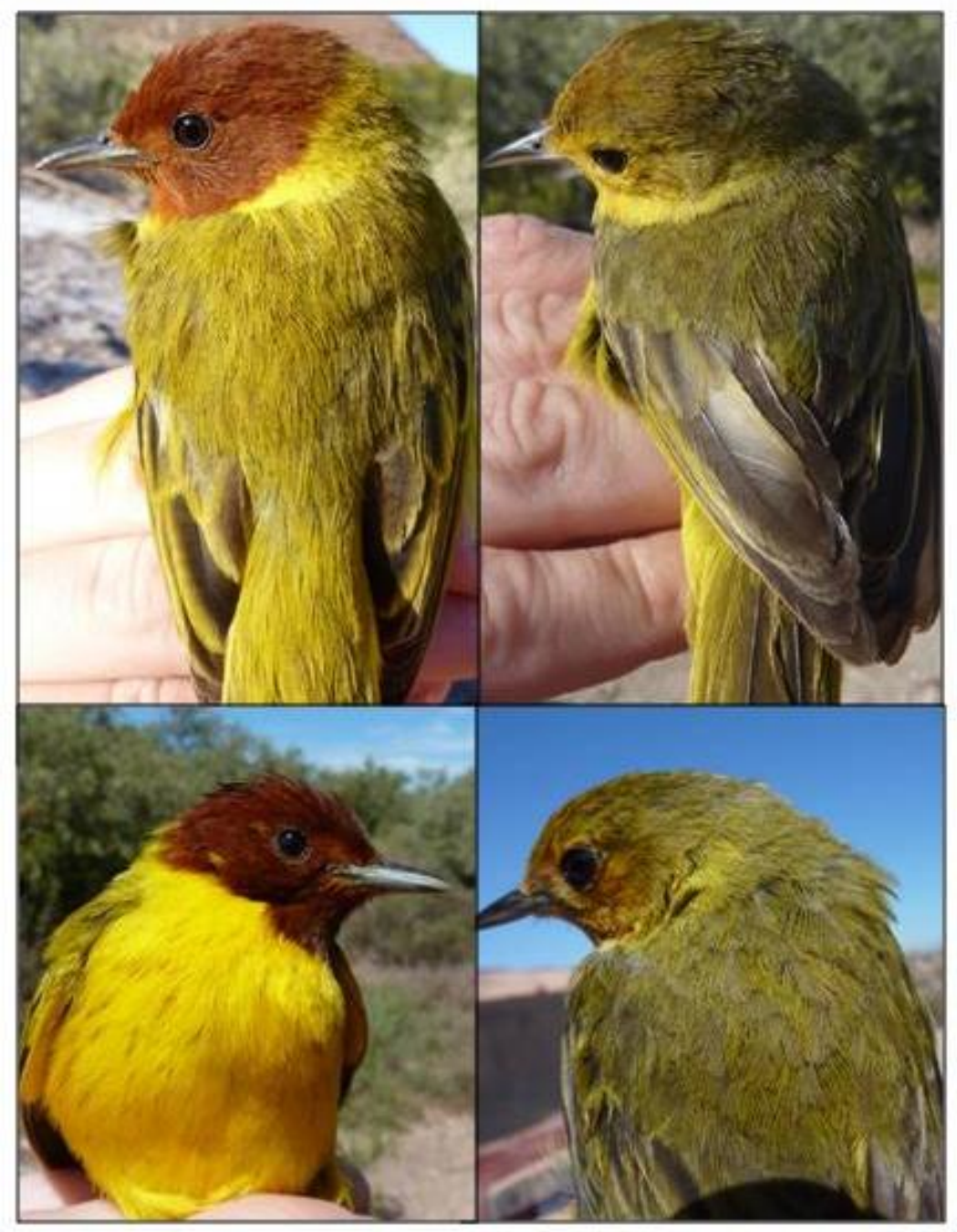

Fig. 1. Mangrove warbler subspecies. Setophaga petechia castaneiceps male (top left), S. p. castaneiceps female (top right), S. p. rhizophorae male (bottom left), S. p. rhizophorae (bottom right). 


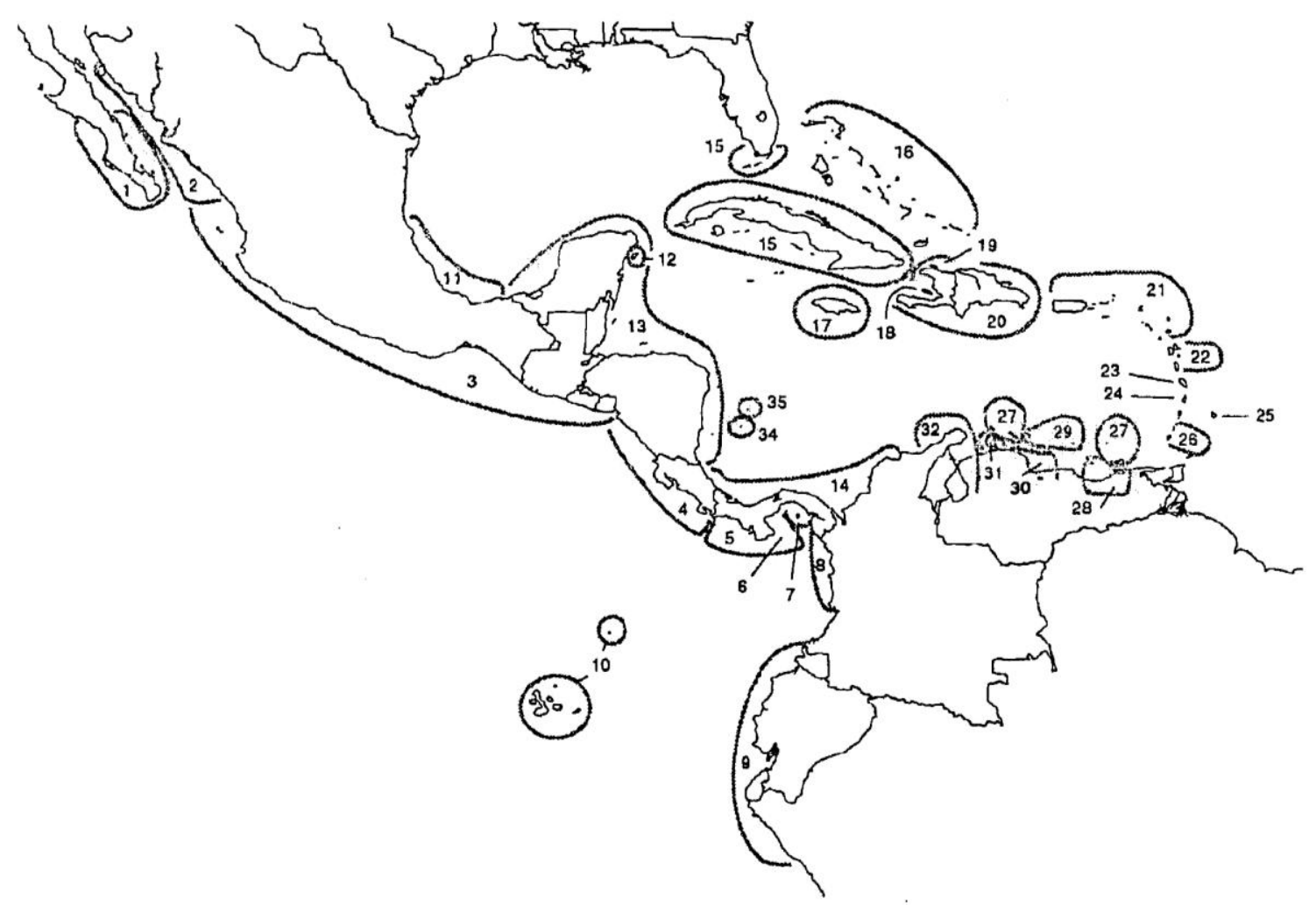

Fig. 2. Breeding ranges of Setophaga petechia in the petechia and erithachorides subspecies groups: 1, castaneiceps; 2, rhizophorae; 3, phillipsi; 4, xanthotera; 5 , aithocorys; 6 , iguana; 7 , aequatorialis; 8 , jubaris; 9 , peruviana; 10, aureola; 11 , oraria; 12, rufivertex; 13, bryanti; 14, erithachorides; 15 , gundlachi; 16, flaviceps; 17, eoa; 18 , solaris; 19, chlora; 20, albicollis; 21, barthomelica; 22, melanoptera; 23, ruficapilla; 24, babad; 25, petechia; 26, alsiosa; 27, rufopileata; 28, aurifroms; 29, obscura; 30, cienagae; 31, paraguanae; 32, chrysendeta; 33, flavida; 34, armouri (from Browning 1994). 


\section{CHAPTER II}

MORPHOLOGICAL VARIATION BETWEEN MANGROVE WARBLER SUBSPECIES IN NORTHWESTERN MEXICO (SETOPHAGA PETECHIA CASTANEICEPS AND S. P. RHIZOPHORAE) 


\section{INTRODUCTION}

Mangroves, coral reefs, and rain forests are the three most productive ecosystems in the world (Holguin et al. 2006). Mangroves are almost exclusively tropical (Hogarth 1999) and provide vital habitat for insects, coastal fish, birds, mammals, reptiles, and other marine species (Laegdsgaard and Johnson 1995; Hogarth 1999; Whitmore et al. 2005). Along with importance to flora and fauna, mangroves are fundamental to their ecosystems by absorbing contaminates from seawater (Tam and Wong 1995), improving seawater quality (Flores-Verdugo et al. 1992), and facilitating soil accretion (Young and Harvey 1996; Hogarth 1999). The soils of mangrove trees store organic carbon, making these ecosystems meaningful in mitigating climate change (Algoni et al. 2001). Mangroves also serve as a great importance to humans as far as alleviating impacts from tsunamis (Kathiresan and Rajendran 2005; Alongi 2008).

Mangroves are spread throughout the coastline of Mexico south of $26^{\circ} \mathrm{N}$ in the Gulf of Mexico and north to $29^{\circ} 20^{\prime}$ in the Gulf of California (Ruiz-Luna et al. 2010). The Gulf of California is the northern edge for the distribution of mangroves in the Eastern Pacific and western hemisphere (Whitmore et al. 2005; Ruiz-Luna et al. 2010). Despite low human density in this area, there is increasing pressure on mangrove stands from anthropogenic activities (e.g. shrimp farming, rice cultivation, and urban development) which has led to localized destruction and fragmentation (Páez-Osuna et al. 2003; Brusca 2004; Glenn et al. 2006). Within twenty years (1972-92), 65\% of mangrove forests in Mexico were destroyed due to anthropogenic disturbance (Herrera-Silveira and Ceballos-Cambranis 2000), 70,000 ha lost between 1993 and 2000 (SEMARNAT 2003) (including 2,300 ha across Northwestern Mexico (early 1970's to 2005) (Ruiz-Luna et al. 2010)), and over 50\% of mangroves have been destroyed worldwide (Holguin et al. 2006). Due to the historically isolated nature of mangroves and their importance 
to ecosystem function, there is great need to study these unique habitats and preserve their biodiversity.

Throughout the last decade, numerous mangrove protection laws have been enacted and amended in Mexico. In 2003, mangrove management in Mexico was regulated by the Mexican Official Norm (standard: NOM-022-SEMARNAT-2003) which “established the specifications for preservation, conservation, sustainable use and restoration of the coastal wetlands in mangrove areas" (Diario Oficial de la Federación, 10 Abril de 2003). This law allowed for the enforcement of mangrove protection, until the agreement to add Article 4.43 (2004) which states "the prohibition of work and activities set out in paragraphs 4.4 and 4.22 and the limits set out in paragraphs 4.14 and 4.16 may be excluded if there is a preventative report of environmental impact statement, or if the case establishes compensation arrangements for the benefit of wetlands and it obtains corresponding land use change authorization" (Diario Oficial de la Federación, 3 Mayo de 2004). This addition gained immediate attention from many environmental organizations spurring for additional actions and reviews of the article. In 2007 another article was added (Article 60 TER of the Wildlife General Law), in which "it is forbidden to remove, fill, transplant, prune, or conduct any work or activity which directly or indirectly affects mangroves" (Diario Oficial de la Federación, 1 Febrero de 2007). Under this addition, Mexico prohibited nearly all urban development that was harmful to mangrove ecosystems. As with any legislation, however, there are many shortcomings, 'loopholes', and ways to manipulate these laws to satisfy personal interests resulting in mangrove harm and destruction. This has led to creating small, isolated patches of mangrove stands and consequently isolated populations of wildlife which inhabit this habitat. 
Although some bird species opportunistically frequent mangroves, few birds specialize in these forests and detailed research of the ecology of confined mangrove birds is sparse (Hogarth 1999; Luther and Greenberg 2009). Mangrove Warblers (Setophaga petechia castaneiceps and S. p. rhizophorae) are small, tropical songbirds that are subspecies of the Yellow Warbler (Setophaga petechia). They are mangrove specialists and are endemic to the Pacific and Atlantic coasts of Mexico, Central and northern South America (Browning 1994). The nominate species, Yellow Warbler, is one of the most widespread of all warblers, breeding from Alaska south to northwestern Peru, including the Galapagos islands (Curson et al. 1994). The generalization that temperate birds differ from tropical species in life-history traits, survivorship, and behavior is widely accepted. Despite these acceptances, foundational ecological data are absent for most tropical species.

The biometry of the Yellow Warbler has been well studied across its range (Wiedenfeld 1991), but only a few studies, consisting of limited samples on study skins, have been carried out on the Mangrove Warbler subspecies (S. p. spp.) in Mexico (Ridgeway 1885, 1902; Van Rossem 1935,1947). Variations in morphometric traits are often coupled with variation in other morphological, physiological, and/or behavioral traits, both within and among species (Schluter and Smith 1986; Gustafsson 1988; Molina-Borja and Rodríguez-Domínguez 2004; Putnam and Flueck 2011). This variation in traits can influence survival and reproduction (Garland and Losos 1994; Rodriguero et al. 2002). Life-history of an individual can therefore be highly influenced by variation in morphometric traits. Biometric studies, in concurrence with other research, can be useful to further our understanding of the distribution and ecology of the Mangrove Warbler and therefore improve conservation efforts (Atkinson et al. 1981; Telleria and Carbonell 1999; Campos et al. 2005). 


\section{OBJECTIVE}

The main objective of this study was to define the biometric differences between and within the subspecies $S$. p. castaneiceps and $S$. p. rhizophorae.

\section{HYPOTHESIS}

I hypothesize that the two subspecies, $S . p$. rhizophorae and $S$. . castaneiceps, will vary in morphological traits. While I believe these two subspecies will be similar in many morphological measurements, I feel there will be certain characteristics that will be unique not only between subspecies, but also among the isolated populations inhabiting different study areas.

Ho: $S$. p. castaneiceps will not differ from $S$. p. rhizophorae in morphology

Ha: There will be a difference in morphology between $S$. p. castaneiceps and

\section{S. p. rhizophorae}

I believe the adult male Mangrove Warblers of each subspecies will show significant differences from the adult females of their respective subspecies. I also believe there will be differences in mean morphological characteristics between the total adult populations of each study area when compared within a subspecies. I expect to find variation among the study areas

for both $S$. p. castaneiceps and S. p. rhizophorae. Each of these hypotheses will be tested to examine the overall morphological differences between/within subspecies. 


\section{STUDY AREA}

The study area included the known range of S. p. castaneiceps and S. p. rhizophorae. S. p. castaneiceps inhabits patches of mangroves from both coasts of central Baja California Sur from San Ignacio and Pond lagoons south to about $27^{\circ} \mathrm{N}$ on the Gulf of California (Browning 1994; Dunn and Garrett 1994). S. p. rhizophorae inhabits patches of mangrove on coastal Sonora from Tepopa Bay to Mazatlán, Sinaloa, Mexico (Browning 1994). Samples were only taken south to Yavaros, Sonora due to subspecies integration with S. p. phillipsi at Mazatlán (Browning 1994; Dunn and Garret 1997) and travel restrictions in Sinaloa, Mexico.

Baja California Sur and Sonora have an annual precipitation $<300 \mathrm{~mm}$ and mean temperatures of $20-22^{\circ} \mathrm{C}$ (Ruiz-Luna et al. 2010) classifying this as an arid climate. Mangroves in this study are represented by three species, Avicennia germinans (black mangrove), Rhizophora mangle (red mangrove), and Laguncularia racemosa (white mangrove) (Hogarth 1999; Flores-Verdugo et al. 1992; Ruiz-Luna et al. 2010). Although there are no consistent patterns in species distribution or assemblage structure of mangroves in Mexico (Ruiz-Luna et al. 2010), study areas in Baja California Sur were dominated by red mangrove and black mangrove in Sonora. Mangrove trees in Baja California Sur and Sonora seldom exceed $5 \mathrm{~m}$ in height (Felger et al. 2001).

For S. p. castaneiceps, I placed study sites in Baja California Sur based on locations described in Whitmore et al. (2000). There were 18 study sites in Baja California Sur located within 5 major study areas: La Paz, Magdalena Bay, Puerto Adolfo López Mateos (hereafter referred to as PALM), Mulegé and San Lucas (Fig. 1-6). Fourteen sites were situated on the Sea of Cortez coastline. Each study site was designated as a mangrove stand separated by inhospitable habitat from the next closest stand. 
All study sites on the west side of the Sea of Cortez were less than $1.8 \mathrm{~km}$ (straight line distance) across at greatest distance (length or width) and all were isolated patches separate from each other. All but one study site (LP6) on the Sea of Cortez coast for S. p. castaneiceps were $<6$ ha in total area (Table 1). Magdalena Bay is a large continuous mangrove stand on the Pacific Coast of Baja California Sur. It stretches (straight line distance) approximately $115 \mathrm{~km}$ along the coast. The entire study area for $S$. $p$. castaneiceps spanned a total straight line distance of $390 \mathrm{~km}$ and cumulative total area of 127.5 ha in Baja California Sur, Mexico. The overall average distance between neighboring study sites was $6.6 \mathrm{~km}$, but ranged from $0.9 \mathrm{~km}$ to $31.8 \mathrm{~km}$ (Table 1).

For S. p. rhizophorae, there were 13 study sites in Sonora, located within four major study areas: Bahia Kino, San Carlos, La Piedra, and Yavaros (Fig. 7-11). I assigned study sites to mangrove stands that were separated by inhospitable habitat from the next closest stand. All study sites run along the east coast of the Sea of Cortez and were less than $0.4 \mathrm{~km}$ (straight line distance) across at their widest point. All but three study sites were $<6.2$ ha in size (Table 1 ). The entire study area for S. p. rhizophorae spanned a total straight line distance of $339 \mathrm{~km}$ and cumulative total area of 74.1 ha in Sonora, Mexico. The overall average distance between neighboring study sites was $1.2 \mathrm{~km}$, but ranged from $<0.1 \mathrm{~km}$ to $9.4 \mathrm{~km}$ (Table 1 ).

\section{METHODS AND MATERIALS}

\section{Data Collection}

Mangrove Warblers were captured during the breeding season (March-July 2010 and 2011) at each study site in Baja California Sur and Sonora using mist nets and playback 
recordings of their songs as a decoy. Within any study site, multiple locations (i.e. net lanes) were used to conduct necessary field work. I captured as many individuals as possible to maximize the sample size.

Each bird was banded with a U.S. Geological Service aluminum band and unique color combination (4 color plastic bands) for individual identification (Permit \# 20580). The leg containing the federal band was marked with a color band corresponding to one of the major study areas. The other leg was marked with three color bands. At the time of capture, all locations were recorded via GPS unit with a minimum of $10 \mathrm{~m}$ accuracy. After processing, individuals were released at point of capture.

Age was determined through plumage and skull pneumatization (Howell and Webb 1995; Pyle 1997). Birds were categorized into hatch year (HY) and after hatch year (AHY) year classes. If identified, more detail was noted to further age individuals of AHY to either second year (SY) or after second year (ASY). Sex, male (M) or female (F), was determined through coloration and presence of brood patch/cloacal protuberance (Howell and Webb 1995; Pyle 1997). All individuals that were not capable of being sexed were classified as unknown (U). Skull pneumatization was based on a 0-6 scale, where 0 indicated no ossification and 6 indicated full ossification of the skull. A class 6 skull indicated an AHY individual.

\section{Biometric Measurements}

My measurements were made in accordance to Pyle (1997), unless noted. I took fat and breast muscle measurements to assess body condition. Sub-epidermal fat was measured by inspecting the abdomen and furcula of every bird. I assigned fat amounts to a class based on a 07 scale, where 0 was no fat present in the furcula and abdomen and a score of 7 was much fat 
where nearly the entire ventral side of the bird is covered with fat, extending up to the neck and head (DeSante et al. 2008). Muscle was scored on a 0-3 scale where 0 corresponded to a prominent ridge on the sternum displaying depressed pectoral muscles (pectoralis major and pectoralis minor) and concavity of the pectoral muscles next to the keel. Well developed, enlarged pectoral muscles where the sternum was barely distinguished was scored as 3 (Bairlein 1995).

I measured unflattened wing chord measurements $(0.5 \mathrm{~mm})$ using a wing rule with a perpendicular stop at zero. Tail length was taken between the two central retrices (R6) from the base of the tail to tip of feather $(0.5 \mathrm{~mm})$. Total length of the bird measured from the tip of the bill to tip of the tail while the bird was straightened out on its back. The head was laid back flat against the ruler, neck not stretched, until the tip of the bill hit the perpendicular stop at zero ( $0.5 \mathrm{~mm})$ (Svensson 1994).

Tarsus length was measured with vernier calipers when the foot was bent at a 90 degree angle towards the tarsometatarsal bone. Measurements were taken from the notch on the intertarsal joint to the distal end of the last leg scale before the toes begin. Bill length (exposed culmen) was measured from the tip of feathering at the base of the bill to the tip of the bill using vernier calipers $(0.1 \mathrm{~mm})$. Bill (culmen) depth was also measured with vernier calipers from the anterior edge of the nostrils to the notch in lower mandible $(0.1 \mathrm{~mm})$. Using a $30 \mathrm{~g}$ Pesola spring scale, I measured the weight of the birds to the nearest $0.1 \mathrm{~g}$. I also took uniform photographs of each bird for reference and comparison. 


\section{Data Analyses}

Only banded birds with data collected for each measurement variable were used for analysis. Birds that were of unknown age or sex were eliminated from analyses (1.6\%). Prior to analyses, we tested variables for normality using a histogram. Variables were approximately normally distributed and all analyses were based on untransformed data. We summarized biometric measurements using Principal Component Analysis (PCA). We chose the first two principal components for regression analysis and graphical exploration based on eigenvalues (>1) and screeplot examination.

We performed Multivariate Analysis of Variance (MANOVA) to test if differences existed between subspecies, sex, and study areas. We used subspecies, sex, and study areas as the predictor variables and morphometric measurements as the response variables. These tests were completed using statistical software R (version 2.12.0).

For each subspecies, we then used statistical software SAS (version 9.2) to run MANOVA and ANOVA with post-hoc contrasts for each morphometric measurement (sex and age combined) with the study areas as the predictor variables. For the contrasts, the mean of a morphological measurement (e.g. mean wing chord) for a study area (e.g. La Paz) was compared to the mean of a morphological measurement of the combined remaining study areas (e.g. mean wing chord of all individuals in San Lucas, Mulegé, Magdalena Bay, and PALM). In S. p. castanceips we did a contrast combining the mean of Magdalena Bay and PALM against all other study areas because they were both situated on the Pacific Coast situated in fairly continuous mangrove stands compared to the highly fragmented and isolated mangrove stands on the Sea of Cortez. A result was significant when $\mathrm{p}<0.05$. 


\section{RESULTS}

\section{Capture Success}

Overall in the $S$. p. castaneiceps subspecies, there were a total of 87 AHY males (72 ASY, 15 SY) and 42 AHY females (29 ASY, 13 SY) banded during the breeding season at a total of 74 capture locations within the 5 study areas. There were 63 AHY males (47 ASY, 5 SY) and 11 AHY females (10 ASY, 1 SY) S. p. rhizophorae individuals banded at a total of 48 capture locations within 4 study areas (Fig. 12).

\section{Subspecies Comparison}

S.p. castaneiceps and S. p. rhizophorae populations were clearly different based on morphometric measurements $(\mathrm{F}=63.91, \mathrm{dF}=1, \mathrm{P}=<0.001)$ (Table 2, Fig. 13). S. p. castaneiceps were larger than S. p. rhizophorae. Overall, the Mangrove Warblers $(n=203)$ averaged a 63.7 $\mathrm{mm}$ wing chord, $11 \mathrm{~mm}$ bill length, $3.7 \mathrm{~mm}$ bill depth, $21.5 \mathrm{~mm}$ tarsus length, $50.6 \mathrm{~mm}$ tail length, $115.2 \mathrm{~mm}$ total length, 11.1g weight (Table 3).

The first two principal components explained $74 \%$ of the overall variance (PC1 57\%, PC2 18\%) between S. p. castaneiceps and S. p. rhizophorae (Table 4). PC1 describes the overall size of the bird, with highest factor loadings on total length, weight, wing chord and tarsus length, whereas PC2 describes primarily bill shape (Table 5).

\section{Sex Comparison}

Morphometric measurements were significantly different for sexes within each Mangrove Warbler subspecies $(\mathrm{F}=24.64, \mathrm{dF}=1, \mathrm{P}=<0.001)$ (Table 2). Males were larger than females overall, but were closely related in bill length, bill depth, and tarsus length (Table 3). There was no interaction between subspecies and sex $(\mathrm{F}=0.55, \mathrm{dF}=1, \mathrm{P}=0.79)$ (Table 2). 


\section{Age Class Comparison}

Slight morphometric variation was found among age classes, such that ASY individuals (both males and females) were generally larger than SY individuals in S. p. castaneiceps and $S$. p. rhizophorae. Bill length, bill depth, and tarsus length had the least variation and most overlap between the age classes (Table 3).

\section{Variation Among Study Areas}

Morphometrics varied significantly among the $S$. p. castaneiceps study areas $(\mathrm{F}=1.95$, $\mathrm{dF}=5, \mathrm{P}=0.001)$ and among the $S . p$. rhizophorae study areas $(\mathrm{F}=2.97, \mathrm{dF}=3, \mathrm{P}=<0.001)$ (Table $6)$.

\section{S. p. castaneiceps}

Wing chord and bill depth did not differ among the study areas (Table 7). Bill length was significantly different among study area populations $(\mathrm{F}=4.14, \mathrm{dF}=4, \mathrm{P}<0.01)$ (Table 7,8$)$. La Paz and San Lucas populations had longer bill lengths, whereas PALM and the combined Magdalena Bay and PALM study areas averaged shorter bill lengths compared to the overall mean of the other study areas (Fig. 14). Tarsus length was significantly different overall (F= 2.76, $\mathrm{dF}=4, \mathrm{P}=0.03$ ) (Table 7), with specific difference existing between Magdalena Bay, San Lucas, and the combined Magdalena and PALM study areas (Table 9). Magdalena Bay and the combined Magdalena Bay and PALM study areas averaged a greater tarsus length whereas the San Lucas population exhibited a smaller mean tarsus length comparatively (Fig. 15). Tail length was not significant overall (Table 7), but was different for Magdalena Bay $(\mathrm{F}=7.48, \mathrm{dF}=1$, $\mathrm{P}<0.01$ ) (Table 10) as it had a greater mean length (Fig. 16). Total length varied significantly among the study areas $(\mathrm{F}=2.85, \mathrm{dF}=4, \mathrm{P}=0.03)$ (Table 7) with differences existing between mean 
total length of the Magdalena Bay $(\mathrm{F}=7.45, \mathrm{dF}=1, \mathrm{P}=<0.01)$ and the combined Magdalena Bay and PALM populations $(\mathrm{F}=7.04, \mathrm{dF}=1, \mathrm{P}=<0.01)$ (Table 11) such that they were larger (Fig. 17). Weight of the La Paz population was less (Fig. 18) and significantly different compared to the mean weight of the other study area populations $(\mathrm{F}=11.82, \mathrm{dF}=1, \mathrm{P}<0.001)$ (Table 12). The combined populations of Magdalena Bay and PALM were also significantly different $(\mathrm{F}=8.70$, $\mathrm{dF}=1, \mathrm{P}<0.01)$ (Table 12) as they had a greater weight comparatively (Fig. 18).

\section{S. p. rhizophorae}

Bill length and bill depth measurements did not differ among study areas (Table 13). Wing chord differed significantly overall among the study areas $(\mathrm{F}=6.13, \mathrm{dF}=3, \mathrm{P}=0.001)$ (Table 13) with San Carlos study area exhibiting a significantly larger mean wing chord and Bahia Kino study area a smaller mean wing chord (Table 14, Fig. 19). Tarsus length was not significant overall (Table 13), but was different for Yavaros $(\mathrm{F}=5.84, \mathrm{dF}=1, \mathrm{P}=0.02)($ Table 15) as it had a greater mean length compared to the other study areas (Fig. 20). Tail length was significantly different among study areas $(\mathrm{F}=7.58, \mathrm{dF}=3, \mathrm{P}=<0.001)$ (Table 13$)$, but only varied for the Bahia Kino study area where tail length was shorter (Table 16, Fig. 21). Mean total length was significantly greater for San Carlos study area and shorter for Bahia Kino study area comparatively (Table 17, Fig.22). Weight was also significantly different among study area populations overall (Table 13). La Piedra had a slightly smaller mean weight and the Yavaros study area population had a greater mean weight (Table 18, Fig. 23). 


\section{DISCUSSION}

\section{Subspecies Comparison}

Body size and its components are the targets of numerous selective processes (Price 1984; Brown and Brown 2011). Our research confirms S. p. castaneiceps and S. p. rhizophorae differ significantly in morphology. Individuals of $S$. p. castaneiceps are generally larger than individuals of S. p. rhizophorae, and both are greater in overall size than the northern Yellow Warbler (S. p. aestiva) (Widenfeld 1991; Pyle 1997). These differences are substantial and are distinguishable in the field, making it a helpful characteristic for distinguishing between the two subspecies (Cicero and Johnson 2006).

Our results agree with measurement results reported in Curson et al. (1994) for Mangrove Warblers, except for female tail length which was larger in our study. Our results also agree with subspecific characters in Browning (1994) stating S. p. castaneiceps tails are slightly larger than $S$. p. rhizophorae, however we found slightly smaller tails for $S$. p. castaneiceps comparatively. Tail length, however, was highly variable (as seen in boxplots) possibly due to differences in feather wear and molting conditions (Alonso and Arizaga 2006).

Increased body and bill size of passerine birds on islands has been well documented (i.e. Scott et al. 2003; Boyer and Jetz 2010; Greenberg and Olsen 2010) including in mangrove stands representing habitat islands (Luther and Greenberg 2011). Our research supports the idea of "island syndrome" (differences in demography, reproduction, behavior, and morphology compared to mainland populations) such that both Mangrove Warbler subspecies had longer and deeper bills and overall body size compared to Yellow Warblers (Curson et al. 1994; Pyle 1997; Lowther et al. 1999) Changes in bill size and shape are indicators of ecological pressures in local environments, particularly food resources and foraging behavior (Grant and Grant 2002; 
Temeles et al. 2010). Increased bill size may be a result to generalization in resource use (Scott et al. 2003). These observations suggest the need to investigate the relationship between resource availability, habitat preference, and morphology within different mangrove stands in Northwestern Mexico.

\section{Sex Comparison}

The amount of sexual dimorphism in the avian taxa, along with the variety of features that have been subject to sexual selection, is extensive (Shutler and Weatherhead 1990; Andersson 1994). Many birds show sexual difference, usually in color (sexual dichromatism) or size (sexual dimorphism) (Siefferman et al. 2007; Igic et al. 2010), commonly exhibiting more colorful, brighter, and larger males.

Sexual dimorphism in Setophaga warblers varies from modest (such as the Yellowthroated Warbler (Setophaga dominica) exhibiting contrast primarily in dull colors and finer streaking) to extreme (such as in the Black-throated Blue Warbler (Setophaga caerulescens) in which the adult male is bright blue with black patches and the adult female is olive above and buffy below) (Dunn and Garrett 1994). Mangrove Warblers show sexual dimorphism in the presence of a rufous/chestnut head in males and through differences in size. Sex specific variation was observed for all measurements with males from both S. p. castaneiceps and S. p. rhizophorae being larger than females. Tarsus length, bill length, and bill depth measurements however, had very subtle differences between male and females. These differences may not be great due to selection that may act on body size. Males and females, especially in a sedentary, monogamous warbler, spend much of their lives living in close proximity to each other. Using 
the same niche may require similar body characteristics in males and females (Gorrell et al. 2005).

\section{Age Class Comparison}

Our results agree with Lowther et al. (1999) research with Yellow Warblers, such that ASY birds (both males and females) have a greater weight than SY birds. Most distinct differences in age classes of passerines, in general, come from plumage and molt patterns rather than body measurements (Pyle 1997), especially between the ASY and SY age classes.

Age class is mostly important for breeding success such that older birds (ASY) are more successful than younger birds (SY) for reasons such as mate choice, song quality (Poesel et al. 2006), early arrival date, territory quality, and increased parental care at the nest (e.g. Cooper et al. 2009). A greater weight in ASY individuals may be a benefit in defending territories against SY individuals looking to establish a territory.

\section{Variation Among Study Areas}

Morphometric variation was observed among study areas of each Mangrove Warbler subspecies. Habitat characteristics have been shown to influence variation in morphometric measurements for numerous bird species (e.g. Arizaga et al. 2009; Desrochers 2010). In S. p. castaneiceps, the populations on the Pacific Coast (Magdalena Bay and PALM) showed the greatest contrast in morphometric measurements from the populations along the west coast of the Sea of Cortez (La Paz, Mulege, and San Lucas). Generally, the Pacific Coast populations had overall larger body features (tarsus length, tail length, total length, and weight) but smaller bill sizes compared to the Sea of Cortez populations. The Pacific Coast of Baja 
California Sur has cooler temperatures and receives more rainfall annually compared to the Sea of Cortez coast (Brusca 2010) which may be a driving force for morphological variation (Wiedenfeld 1991). Differences in mean temperatures and precipitation can account for changes in environmental conditions such as vegetation, habitat structure, resource availability, and predator presence, which may drive changes in morphology of local populations (Telleria and Carbonell 1999).

S. p. rhizophorae showed a consistent pattern of smaller sized individuals in Bahia Kino (decreased wing length, tail length, and total length) compared to the other study areas in Sonora. The Bahia Kino population was the northern most study area we sampled. As the eastern coast of the Sea of Cortez follows a southward rising temperature gradient and rainfall amount, response of morphological measurements to changes in environment may be occurring (Peinado et al. 2010).

Speciation can occur quickly with high diversity of resources, even with little or no geographical separation (Price 2008). Variation may be explained by various selective pressures (e. g. resources, competition, predation, sexual selection) acting on individual habitat islands (study areas) which might result in changes in life history (Santiago-Alarcon and Parker 2007). 


\section{LITERATURE CITED}

AlONGI, D. M. 2008. Mangrove forests: Resilience, protection from tsunamis, and responses to global climate change. Estaurine, Coastal, and Shelf Science 76:1-13.

Alongi, D. M., G. Wattayakorn, J. Pfitzner, F. Tirendi, I. Zagorshis, G. J. Brunskill, A. AtKinson, N. K., R. W. Summers, M. Nicoll, AND J. J. D. GReENWOOD. 1981. Population, movements and biometrics of the Purple Sandpiper Calidris maritima in Eastern Scotland. Ornis Scandinavica 12:18-27.

Alonso, D. AND J. Arizaga. 2006. Biometrics of Citril Finch Serinus citronella in the West Pyrenees and the influence of feather abrasion on biometric data. Ringing \& Migration 23:116-124

Andersson, M. B. 1994. Sexual selection. Princeton University Press, New Jersey.

ARIZAGa, J., M. Á. HeRnÁNDEZ, J. Rivas, AND R. MiRANDA. 2009. Biometrics of Iberian Dippers Cinclus cinclus: environmental sources of among-population variation. Ardea 97:23-30.

AtKinson, N. K., R. W. Summers, M. Nicoll, AND J. J. D. Greenwood. 1981. Population, movements and biometrics of the Purple Sandpiper Calidris maritima in Eastern Scotland. Ornis Scandinavica 12:18-27.

BAIRLEIN, F. 1995. European-African Songbird Migration Network, Manual of Field Methods. Institut für Vogelforschung, Wilhelmshaven.

Boyer, A. G. AND W. Jetz. 2010. Biogeography of body size in Pacific island birds. Ecography 33:369-379.

BROWN, M. B. AND C. R. BROWN. 2011. Intense natural selection on morphology of cliff swallows (Petrochelidon pyrrhonota) a decade later: did the population move between adaptive peaks? Auk 128:69-77.

Browning, M. R. 1994. A taxonomic review of Dendroica petechia. Proceedings of Biological Sciences Washington 107:27-51.

BRUSCA, R. C. 2004. The Gulf of California-an overview. Pages 1-8 in Seashore Guide to the Northern Gulf of California (R. C. Brusca, E. Kimrey, and W. Moore, eds.). ArizonaSonora Desert Museum, Tucson, AZ.

BRUSCA, R. C. 2010. The Gulf of California: biodiversity and conservation. University of Arizona Press, AZ. 
CAmpos, F., F. Gutiérrez-Corchero, M. A. Hernández, J. M. Rivas, And J. LóPez-Fidalgo. 2005. Biometric differences among the Dipper Cinclus cinclus populations of Spain. Acta Ornithologica 40:87-93.

Cicero, C. And N. K. Johnson. 2006. Diagnosability of subspecies: lessions from sage sparrows (Amphispiza bella) for analysis of geographic variation in birds. Auk 123:266-274.

Cooper, N. W., M. T. Murphy, And L. J. Redmond. 2009. Age-and sex-dependent spring arrival dates of Eastern Kingbirds. Journal of Field Ornithology 80:35-41.

Curson, J., D. Quinn, And D. BEAdle. 1994. New World Warblers. A \& C Black, London.

DECRETO POR EL QUE SE ADICIONA UN ARTÍCULO 60 TER Y SE ADICIONA UN SEGUNDO PÁRRAFO, ARTíCULO 99, TODOS ELLOS DE LA LEY GENERAL DE VIDA SILVESTRE [Decree addition of section 60B and adding a second paragraph to Article 99, all from the Wildlife Act], Diario Oficial de la Federación, [D. O.], 1 Febrero de 2007 (Mex.).

DeSante, D. F., K. M. Burton, P. Velez, D. Froehlick, and D. Kaschube. 2008. MAPS Manual: 2009 Protocol. Contribution No. 127 of The Institute for Bird Populations.

DESROCHERS, A. 2010. Morphological response of songbirds to 100 years of landscape change in North America. Ecology 91:1577-1582.

DIARIO OFICIAL ACUERDO QUE ADICIONA LA ESPECIFICACIÓN 4.43 A LA NOM-022-SEMARNAT2003, QUE ESTABLECE LAS ESPECIFICACIONES PARA LA PRESERVACIÓN, CONSERVACIÓN, APROVECHAMIENTO SUSTENTABLE Y RESTAURACIÓN DE LOS HUMEDALES COSTEROS EN ZONAS DE MANGLAR [Aggreement specifying additional 4.43 to NOM-022-SEMARNAT2003, which sets the specifications for the preservation, conservation, sustainable use and restoration of coastal wetlands in mangrove areas], Diario Oficial de la Federación, [D. O.], 3Mayo de 2004 (Mex.).

DunN, J. L., AND K. L. GARretT. 1997. A Field Guide to Warblers of North America. Houghton Mifflin, Boston.

Felger, R. S., M. B. Johnson, AND M. F. WiLSON. 2001. The trees of Sonora, Mexico. Oxford University Press, New York.

Flores-Verdugo, F., GonZÁlez-Farías, F., Zamorano, D.S. And RamíreZ-García, P. 1992. Mangrove ecosystems of the Pacific coast of Mexico: distribution, structure, litterfall, and detritus dynamics. Pages 269-288 in Coastal Plant Communities of Latin America (U. Seeliger, Ed.). Academic Press, California.

GARLAND, T., AND J. B. LOSOS. 1994. Ecological morphology of locomotor performance in squamate reptiles. Pages 240-302 in Ecological Morphology: Integrative Organismal Biology (P. C. Wainwright and S. M. Reily, Eds.). University of Chicago Press, Chicago. 
Glenn, E. P., P. L. Nagler, R. C. Brusca, And O. HinojosA-Huerta. 2006. Coastal wetlands of the northern Gulf of California: inventory and conservation status. Aquatic Conservation 16:5-28.

Gorrell, J. V., G. Ritchison, And E. S. Morton. 2005. Territory size and stability in a sedentary neotropical passering: is resource partitioning a necessary condition? Journal of Field Ornithology 76:395-401.

GRANT, P. R. AND B. R. GRANT. 2002. Unpredictable evolution in a 30-year study of Darwin's finches. Science 296:707-711.

GreEnBERG, R. AND B. Olsen. 2010. Bill size and dimorphism in tidal-marsh sparrows: islandlike processes in a continental habitat. Ecology 91:2428-2436.

GustafsSOn, L. 1988. Foraging behavior of individual coal tits, Parus ater, in relation to their age, sex, and morphology. Animal Behaviour 36:696-704.

Herrera-Silveira, J., AND E. Ceballos-CAmbranis. 2000. Manglares: ecosistemas valiosos. Biodiversitas 19:1-10.

Hogarth, P. J. 1999. The Biology of Mangroves. Oxford University Press, New York.

Holguin, G., P. Gonzalez-Zamorano, L. E. de-Bashan, R. Mendoza, E. Amador, And Y. BASHAN. 2006. Mangrove health in an arid environment encroached by urban development- a case study. Science of the Total Environment 63:260-274.

Howell, S. N. G., AND S. WeBB. 1995. A Guide to the Birds of Mexico and Northern Central America. Oxford University Press, New York.

Igic, B., N. Leuschner, K. A. Parker, S. M. H. Ismar, B. J. Gill, T. G. Lovegrove, C. D. MiLlaR, AND M. E. HAUBER. 2010. Size dimorphism and avian-perceived sexual dichromatism in a New Zealand endemic bird, the Whitehead Mohoua albicilla. Journal of Morphology 271:697-704.

KATHIRESAN, K., AND N. RAJENDRAN. 2005. Coastal mangrove forests mitigated tsunami. Estuarine, Coastal and Shelf Science 65:601-606.

LAEGDSGARRD, P., AND C. R. JOHnSON. 1995. Mangrove habitats as nurseries: unique assemblages of juvenile fish in subtropical mangroves in eastern Australia. Marine Ecology Progress Series 126:67-81.

Lowther, P. E., C. CeladA, N. K. Klein, C. C. Rimmer, And D. A. Spector. 1999. Yellow Warbler (Dendroica petechia). in The Birds of North America, No. 454 (A. Poole and F. Gill, Eds.). The Birds of North America, Inc. Philadelphia, PA. 
LUther, D. A., AND R. GReENBERG. 2009. Mangroves: A global perspective on the evolution and conservation of their terrestrial vertebrates. BioScience 59:602-612.

LUTHER, D. A. AND R. GREENBERG. 2011. The island syndrome in coastal wetland ecosystems: convergent evolution of large bills in mangrove birds. Auk 128:201-204.

MolinA-BorJa, M., AND M. A. RodríGUEZ-DomínGUEZ. 2004. Evolution of biometric and lifehistory traits in lizards (Gallotia) from the Canary Islands. Journal of Zoological Systematics and Evolutionary Research 42:44-53.

PÁez-Osuna, O., A. Gracia, F. Flores-Verdugo, L. P. Lyle-Fritch, R. Alonso-Rodríguez, A. RoQUe, AND A. C. RuIZ-FERnÁNDEZ. 2003. Shrimp aquaculture development and the environment in the Gulf of California ecoregion. Marine Pollution Bulletin 46:806-815.

Peinado, M., M. A. Macias, J. L. Aguirre, And J. D. Rodriguez. 2010. Bioclimate-vegetation interrelations in northwestern Mexico. Southwestern Naturalist 55:311-322.

Poesel, A., H. P. Kunc, K. Foerster, A. Johnsen, And B. Kempenaers. 2006. Early birds are sexy: male age, dawn song and extrapair paternity in blue tits, Cyanistes (formerly Parus) caeruleus. Animal Behaviour 72:531-538.

PRICE, T. D. 1984. Sexual selection on body size, territory and plumage variables in a population of Darwin's finches. Evolution 38: 327-341.

PRICE, T. 2008. Speciation in Birds. Roberts and Company Publishers, Colorado.

PUTNAM, R. AND W. T. FLUECK. 2011. Intraspecific variation in biology and ecology of deer: magnitude and causation. Animal Production Science 51:277-291.

PYLE, P. 1997. Identification Guide to North American Birds, Part I. Slate Creek Press, California.

RIDGEWAY, R. 1885. A Review of the American "Golden Warblers". Proceedings of the United States National Museum 8:348-350.

RIDGEWAY, R. 1902. The birds of North and Middle America: A descriptive catalogue of the higher groups, genera, species, and subspecies of birds known to occur in North America, from the Arctic Lands to the Isthmus of Panama, the West Indies and other islands of the Caribbean Sea, and the Galapagos Archipelago. Pages 530-531 in Bulletin of the United States National Museum, No. 50, Part II. Washington: Government Printing Office.

Rodriguero, M. S., J. C. Vilardi, M. T. Vera, J. P. CAyol, And E. Rial. 2002. Morphometric traits and sexual selection in Medfly (Diptera: Tephritidae) under field cage conditions. Florida Entomologist 85:143-149. 
Ruiz-Luna, A., A. Cervantes Escobar, and C. Berlanga-Robles. 2010. Assessing distribution patterns, extent, and current condition of Northwest Mexico mangroves. Wetlands 30:717-723.

SANTIAGO-AlarCon AND P. G. PARKER. 2007. Sexual size dimorphism and morphological evidence supporting the recognition of two subspecies in the Galápagos Dove. Condor 109:132-141.

SCHLUTER, D., AND J. N. M. SMITH. 1986. Natural selection on beak and body size in the Song Sparrow. Evolution 40:221-231.

SCOTt, S. N., S. M. ClegG, S. P. BlOMBeRG, J. KikKAWA, AND I. P. F. OWENS. 2003. Morphological shifts in island-dwelling birds: the roles of generalist foraging and niche expansion. Evolution 57:2147-2156.

Secretaria de Medio Ambiente y ReCursos Naturales. NORMA Oficial Mexicana NOM-022-SEMARNAT-2003, QUE ESTABLECE LAS ESPECIFICACIONES PARA LA PRESERVACIÓN, CONSERVACIÓN, APROVECHAMIENTO SUSTENTABLE Y RESTAURACIÓN DE LOS HUMEDALES COSTEROS EN ZONAS DE MANGLAR [Ministry of environment and natural resources. Mexican official standard NOM-022-SEMARNAT-2003, establishing the specifications for the preservation, conservation, development and restoration of coastal wetlands in mangrove areas], Diario Official de la Federación, [D.O.], 10 Abril de 2003 (Mex.).

SHUTLER, D. AND P. J. WEATHERHEAD. 1990. Targets of sexual selection: song and plumage of Wood Warblers. Evolution 44: 1967-1977.

SiEFFERMAN, L., Y. WANG, Y. WANT, AND H. YUAN. 2007. Sexual dichromatism, dimorphism, and condition-dependent coloration in Blue-tailed Bee-eaters. Condor 109:577-584.

SVENSSON, L. 1994. Identification Guide to European Passerines. $4^{\text {th }}$ ed. Stockholm.

TAM, N. F. Y., AND Y. S. WoNG. 1995. Mangrove soils as sinks for wastewater-borne pollutants. Hydrobiologia 295:231-241.

TELleRIA, J. L., AND R. CARBONELl. 1999. Morphometric variation of five Blackcap Slyvia atricapilla populations. Journal of Avian Biology 30:63-71.

Temeles, E. J., J. S. MiLleR, AND J. L. RiFKIN. 2010. Evolution of sexual dimorphism in bill size and shape of hermit hummingbirds (Phaethornithinae): a role for ecological causation. Philosophical Transactions of the Royal Society B Biological Sciences 365:1053-1063.

Van Rossem, A. J. 1935. The Mangrove warbler of Northwestern Mexico. San Diego Society of Natural History 8:67-68. 
VAn Rossem, A. J. 1947. An undescribed race of the mangrove warbler from Baja California, Mexico. Transactions of the San Diego Society of Natural History 11:49-52.

Whitmore, R. C., R. C. Brusca, J. L. L. De LA LuZ, P. GonZÁleZ-Zamorano, R. MendozASalgado, E. S. Amador-Silva, G. Holguin, F. Galván-Magana, P. A. Hastings, J. E. CARTron, R. S. Felger, J. A. SEMInoff, AND C. C. McIvor. 2005. The ecological importance of mangroves in Baja California Sur: conservation implications for an endangered ecosystem. Pages 298-333 in Biodiversity, Ecosystems, and Conservation in Northern Mexico. (J. E. Cartron, G. Ceballos, and F. S. Felger, Eds.). Oxford University Press, New York.

Whitmore, R. C., R. C. Whitmore, And M. M. Whitmore. 2000. Distributional notes on the Mangrove Warbler (Dendroica petechia castaneiceps) near the northern edge of its range in Eastern Baja California Sur, Mexico. Western North American Naturalist 60:228-229.

WIEDENFELD, D. A. 1991. Geographical morphology of male yellow warblers. Condor 93:712723.

Young, B. M., AND E. L. HARVEY. 1996. A spatial analysis of the relationship between mangrove (Avicennia mariana var australasica) physiognomy and sediment accretion in the Hauraki Plains, New Zealand. Estaurine, Coastal, and Shelf Science 42:231-246. 


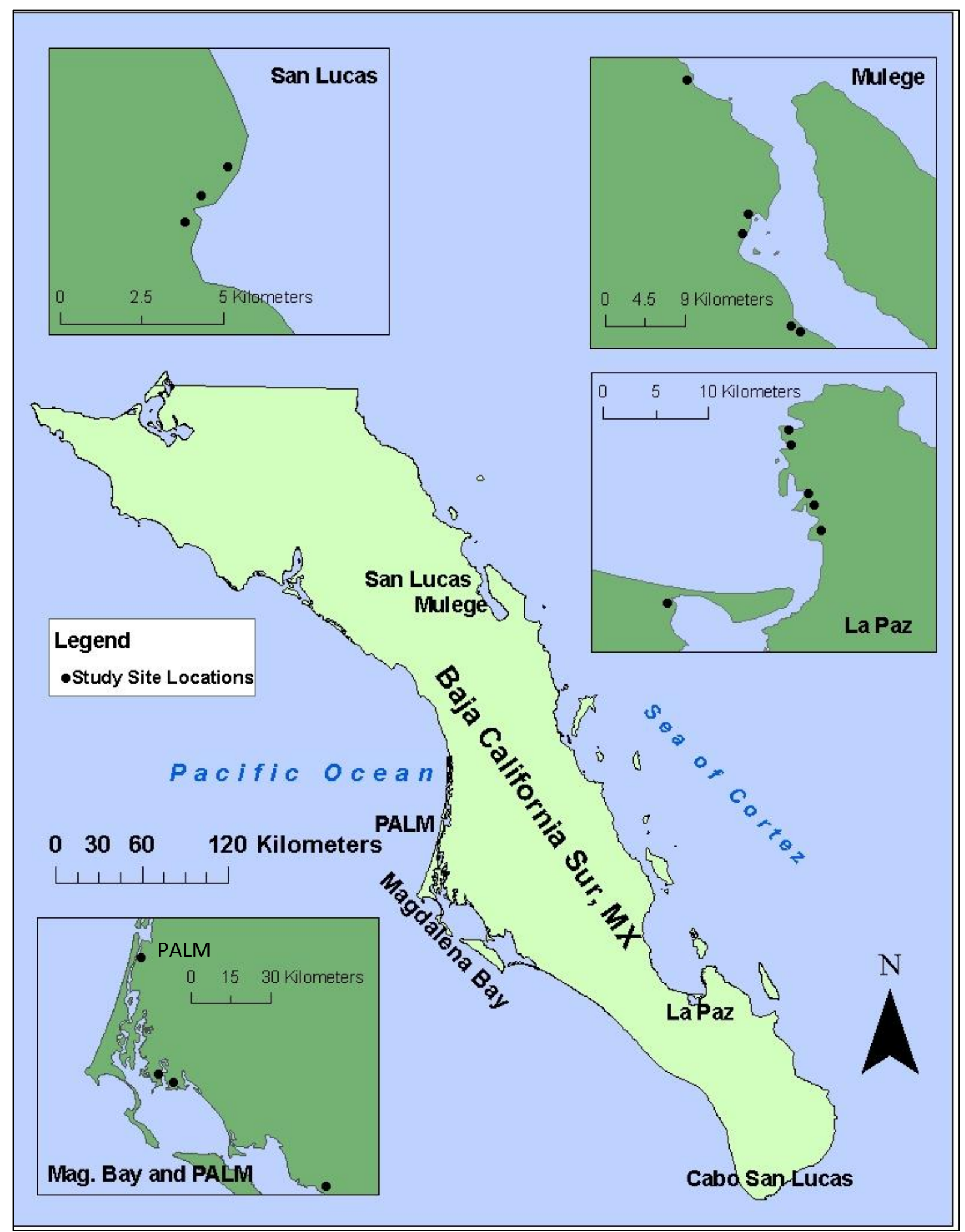

Fig. 1. Distribution and study site locations of S. p. castaneiceps, Baja California Sur, Mexico, with details showing five major study areas (San Lucas, Mulegé, Puerto Adolfo López Mateos (PALM), Magdalena Bay, and La Paz) and study sites within the major study areas. 


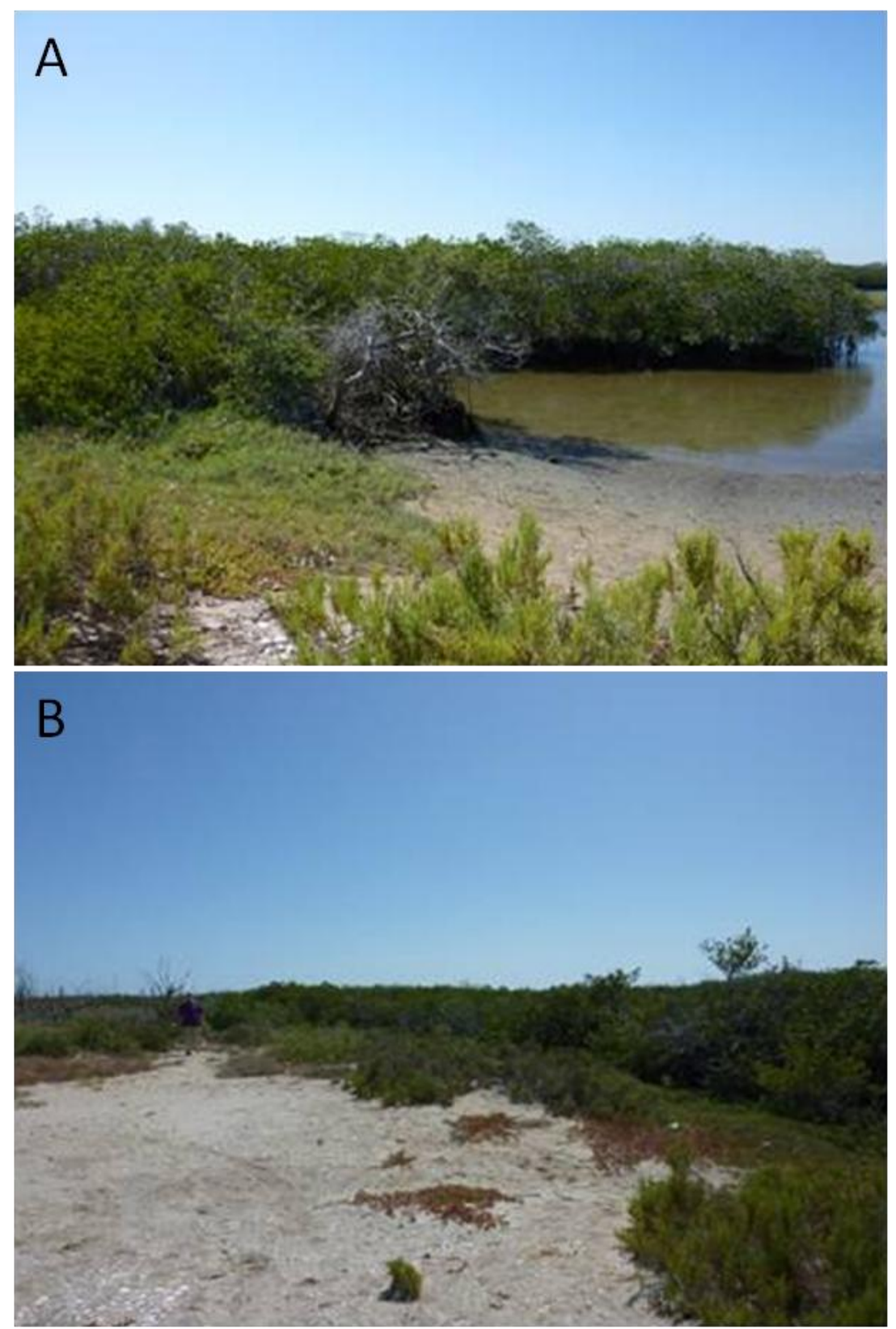

Fig. 2. Magdalena Bay study area, Baja California Sur, Mexico, from lagoon (A) and interior (B). 


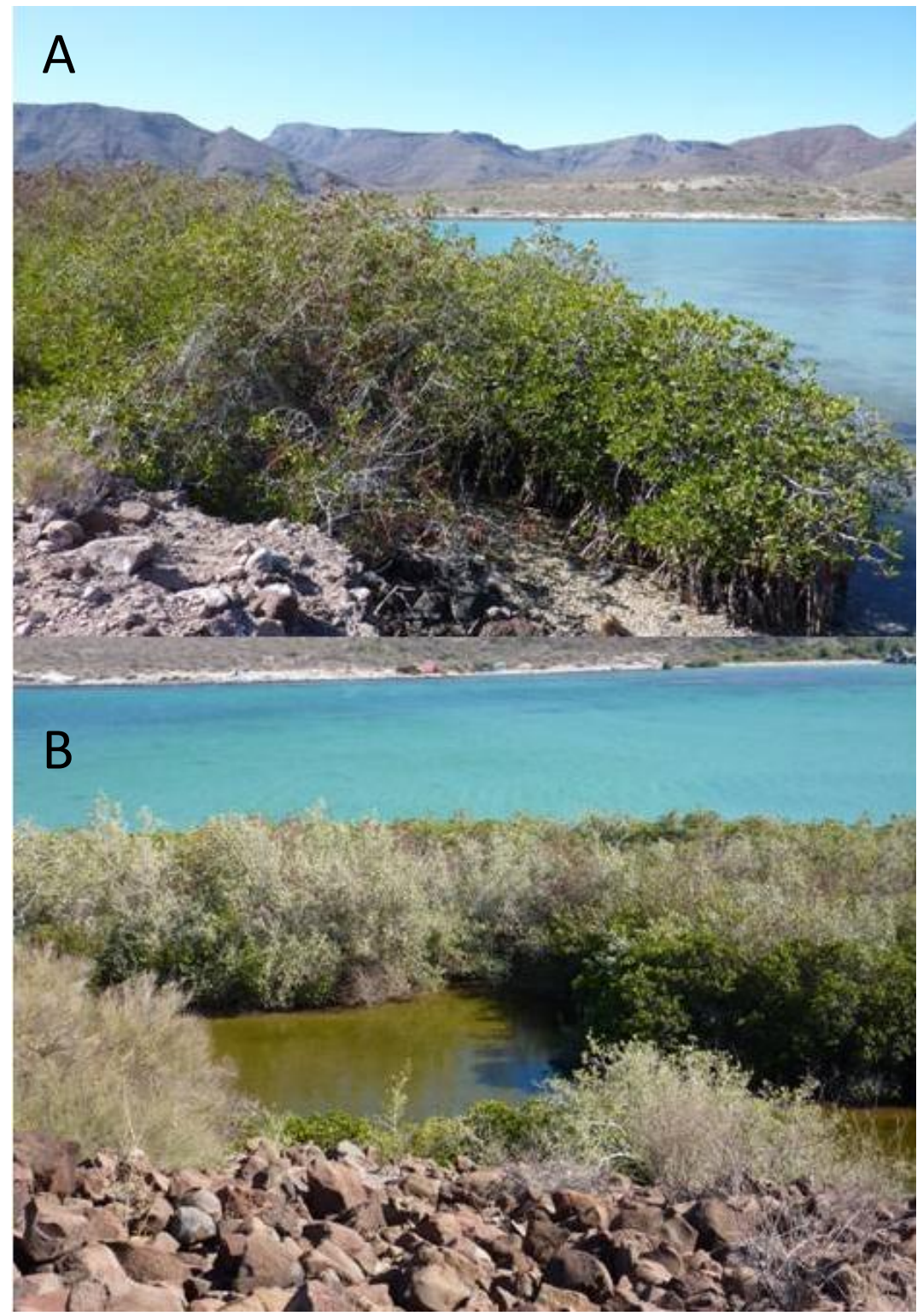

Fig. 3. Mulegé study area, Baja California Sur, Mexico from coast (A) and showing common brackish lagoons within mangrove stands (B). 


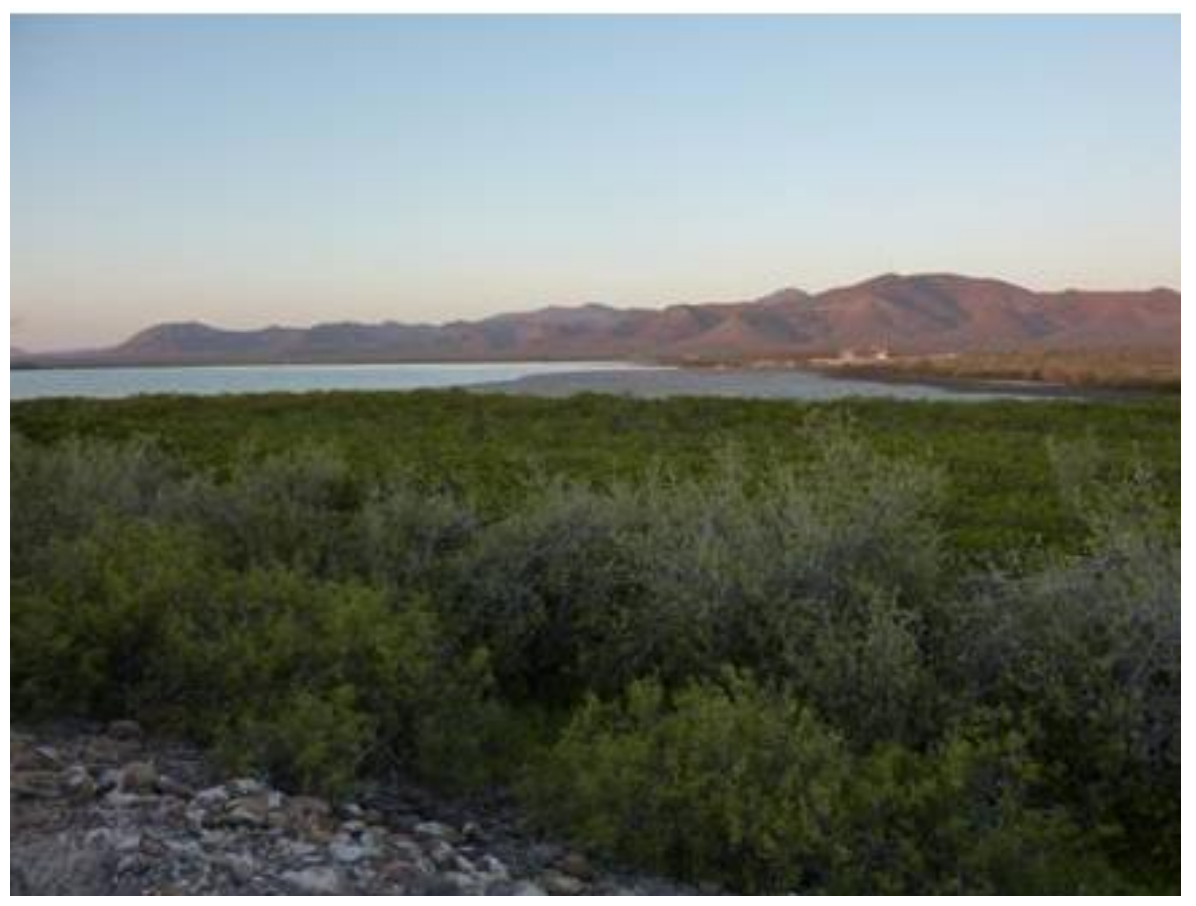

Fig. 4. San Lucas study area, Baja California Sur, Mexico. 

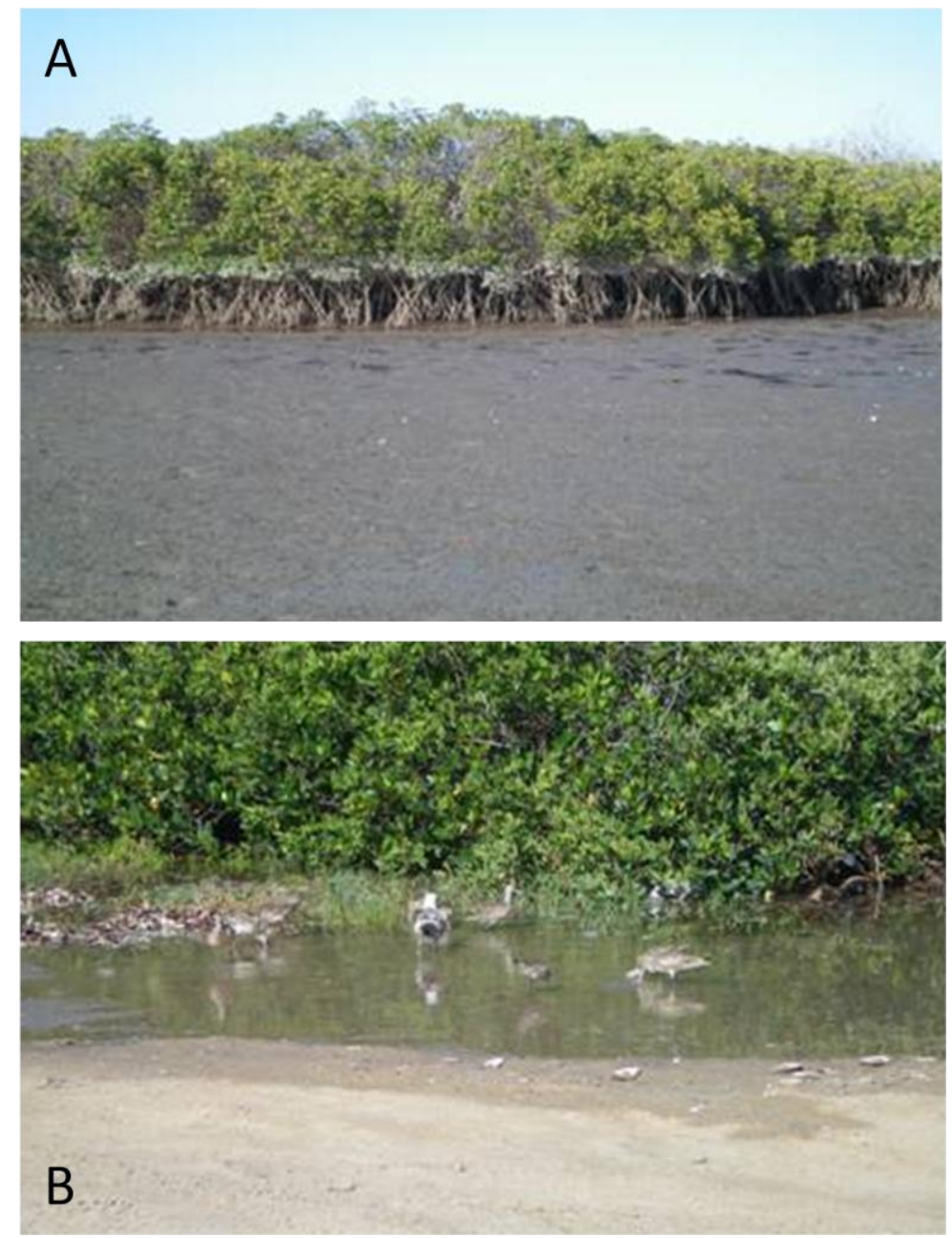

Fig. 5. Puerto Adolfo López Mateos (PALM) study area, Baja California Sur, Mexico from coast at low tide (A) and interior (B). 

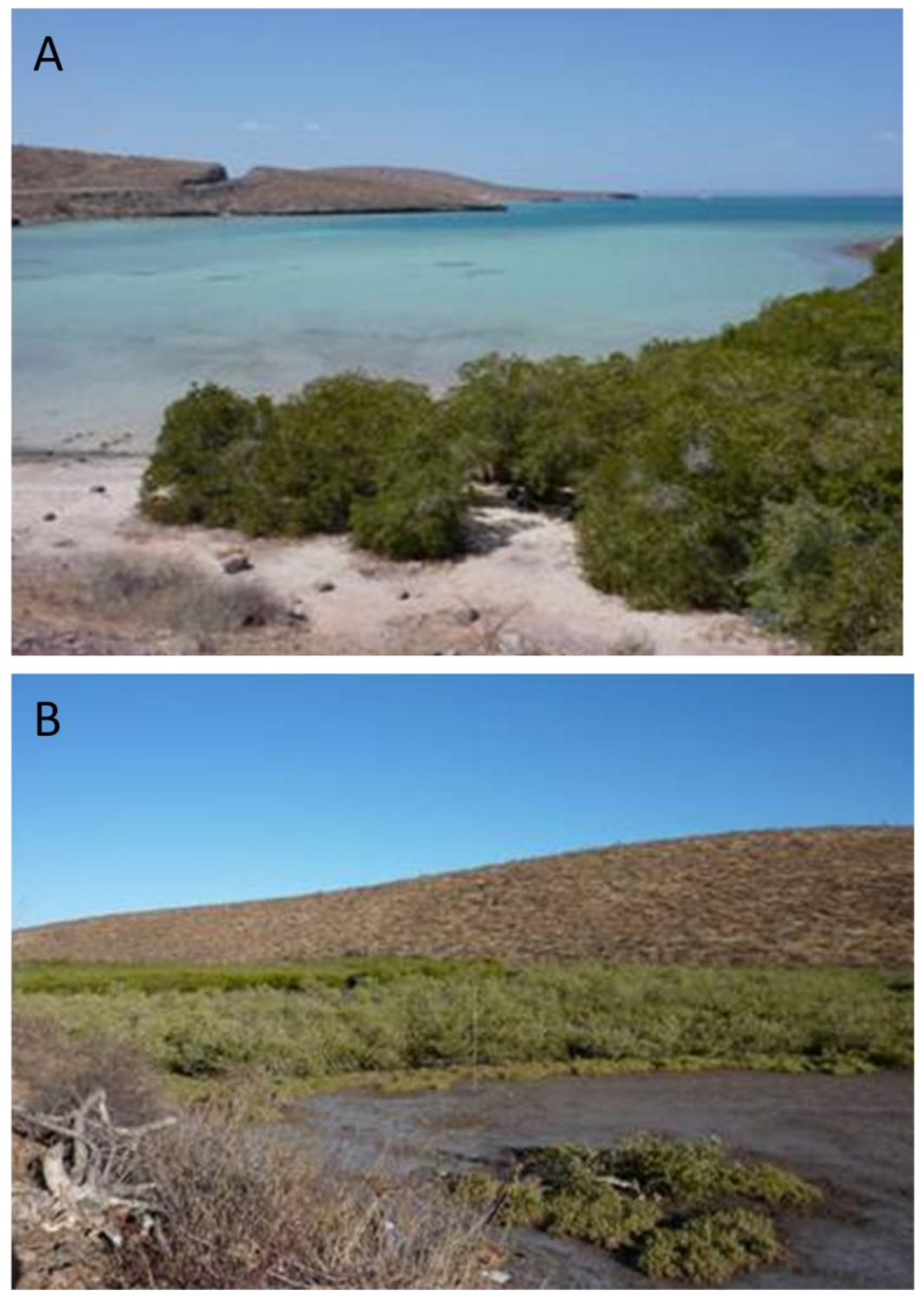

Fig. 6. La Paz study area. Baja California Sur, Mexico from coast (A) and interior (B). 


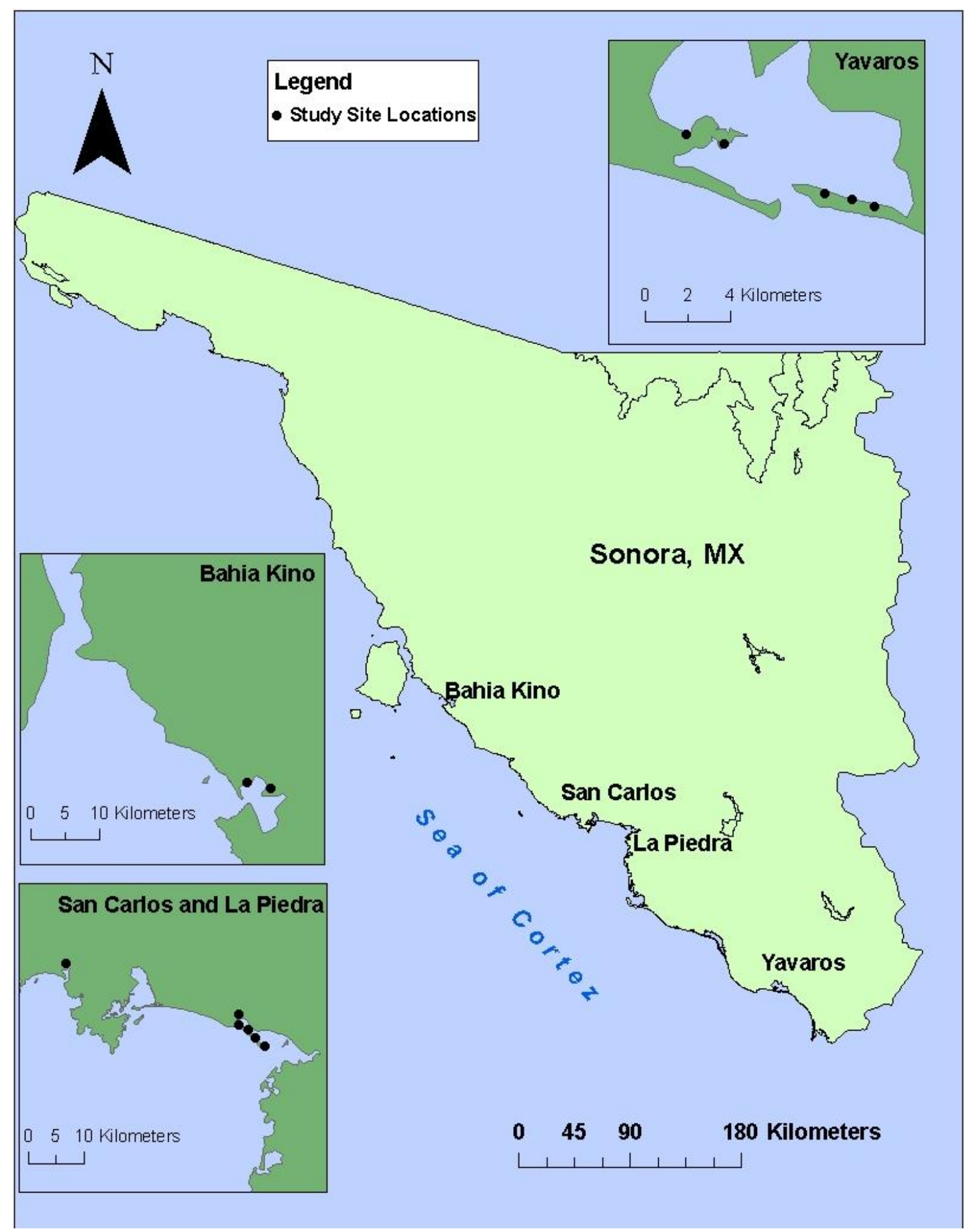

Fig 7. Distribution and study site locations of S. p. rhizophorae, Sonora, Mexico, with details showing four major study areas (Bahia Kino, San Carlos, La Piedra, and Yavaros) and study sites within the major study areas. 


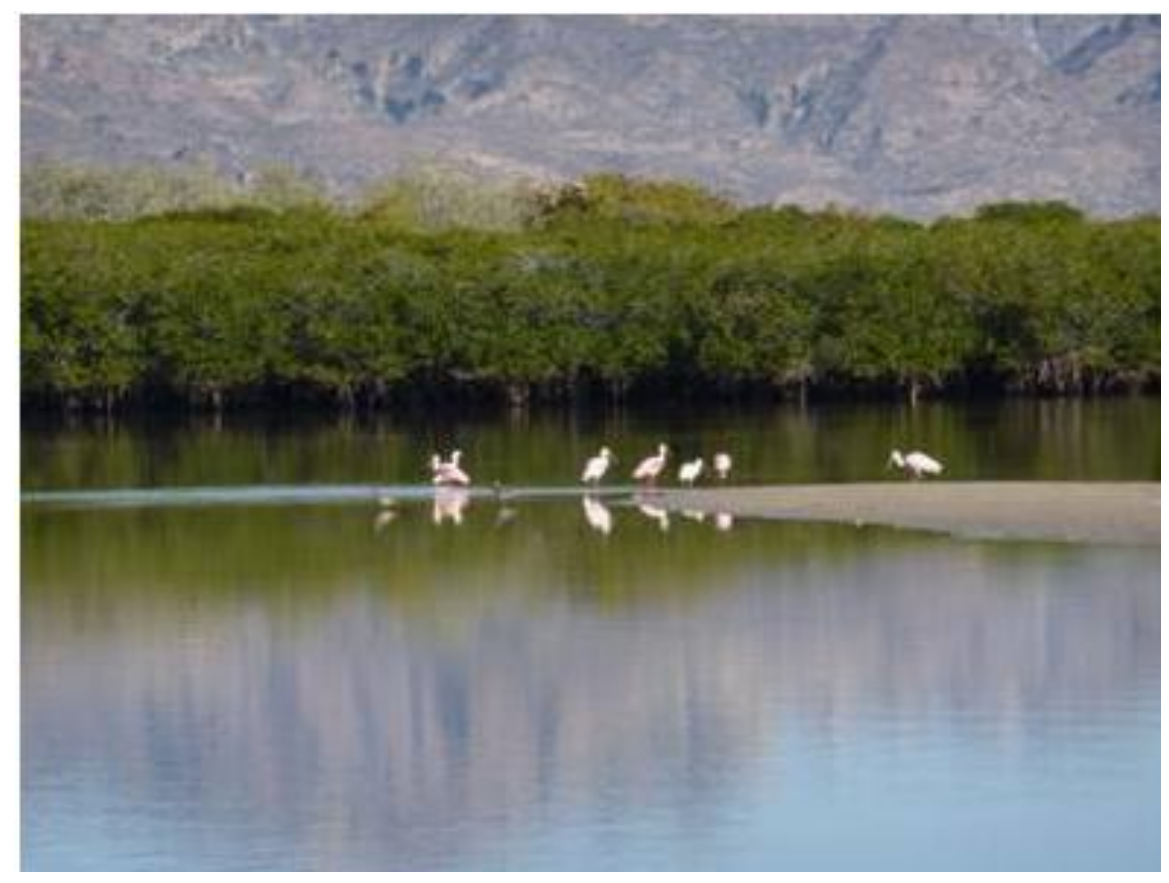

Fig. 8. San Carlos study area, Sonora, Mexico. 


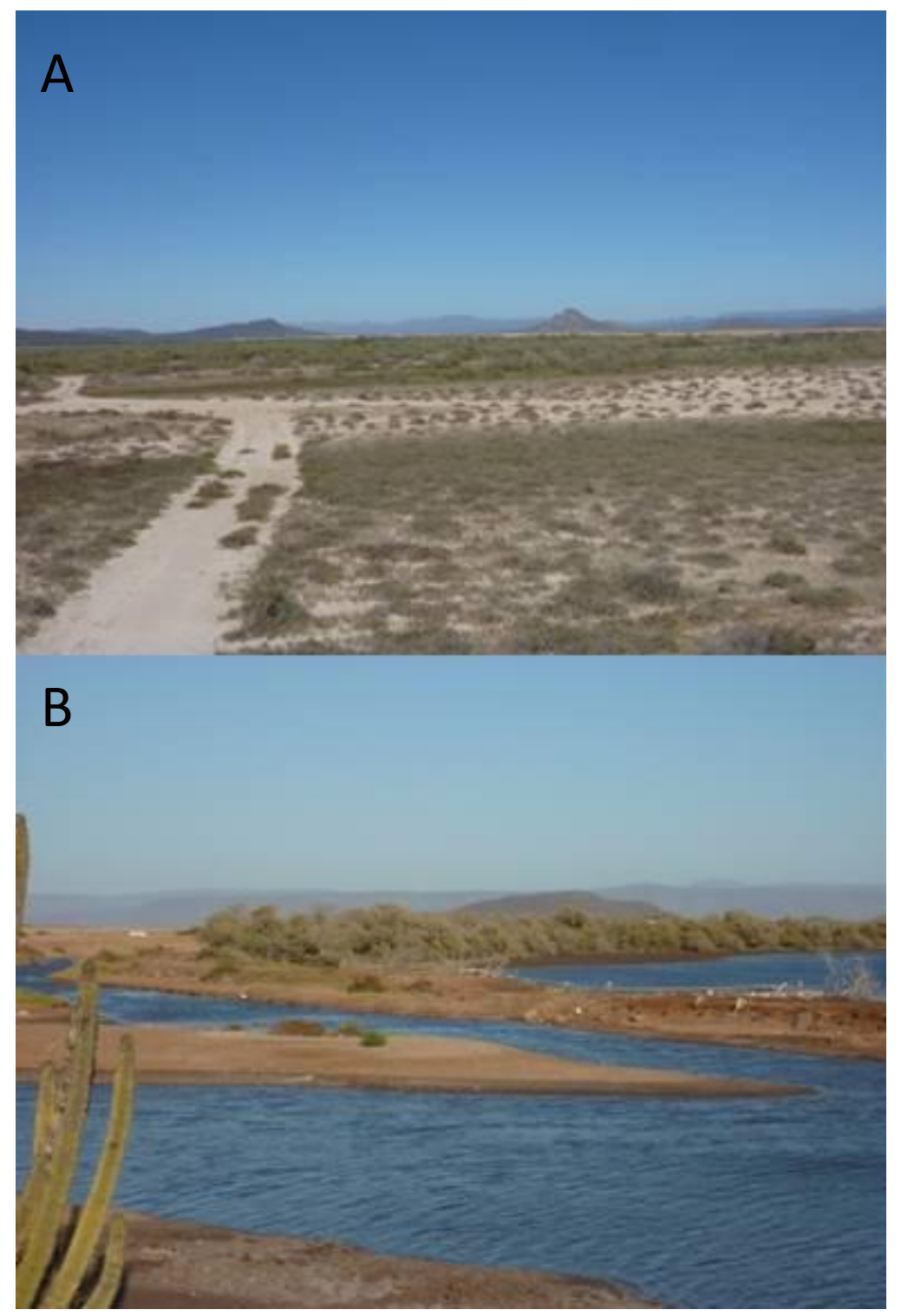

Fig. 9. La Piedra study area, Sonora, Mexico from interior (A) and coast (B). 

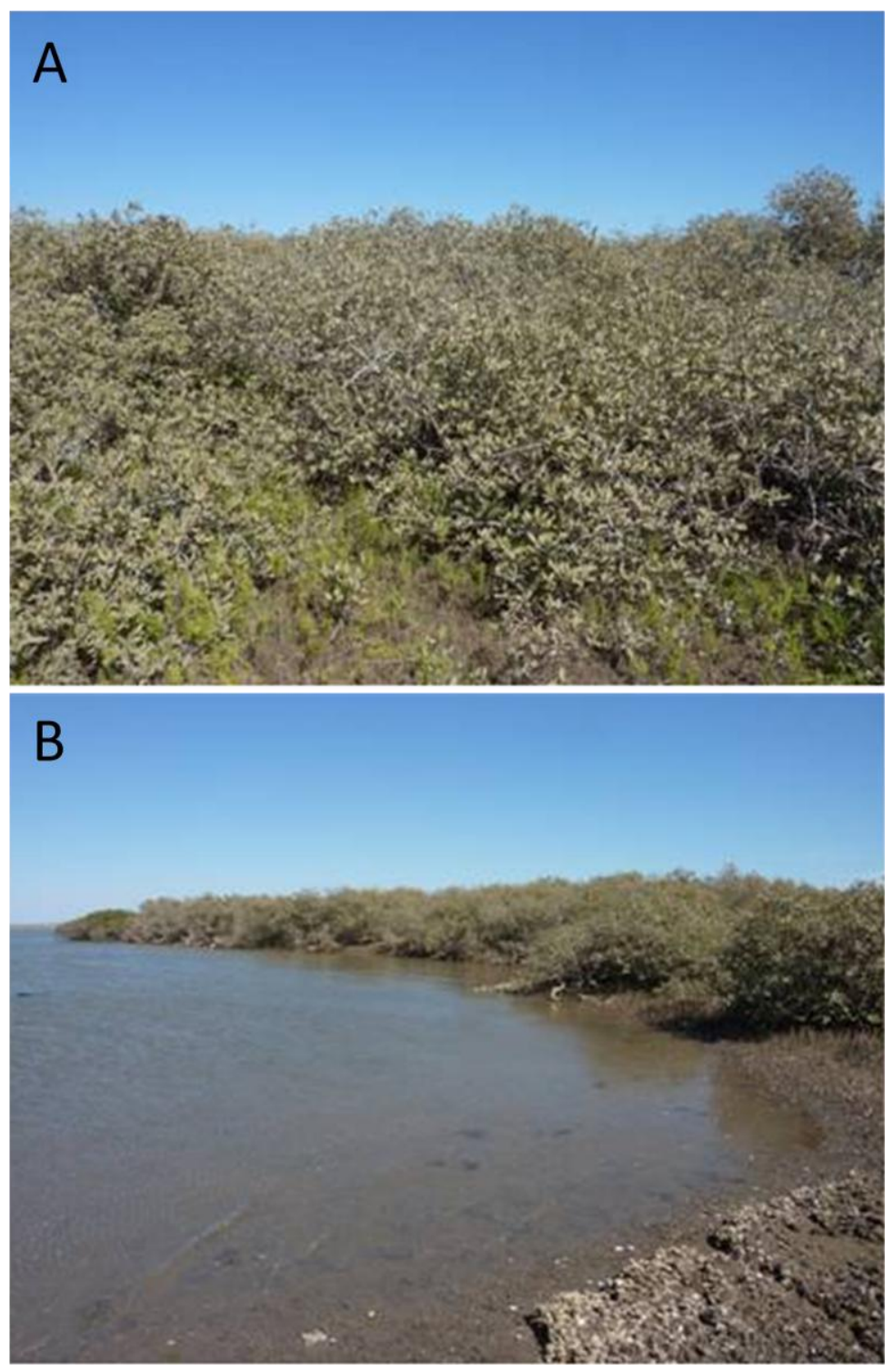

Fig. 10. Yavaros study area, Sonora, Mexico, from interior (A) and from coast (B). 


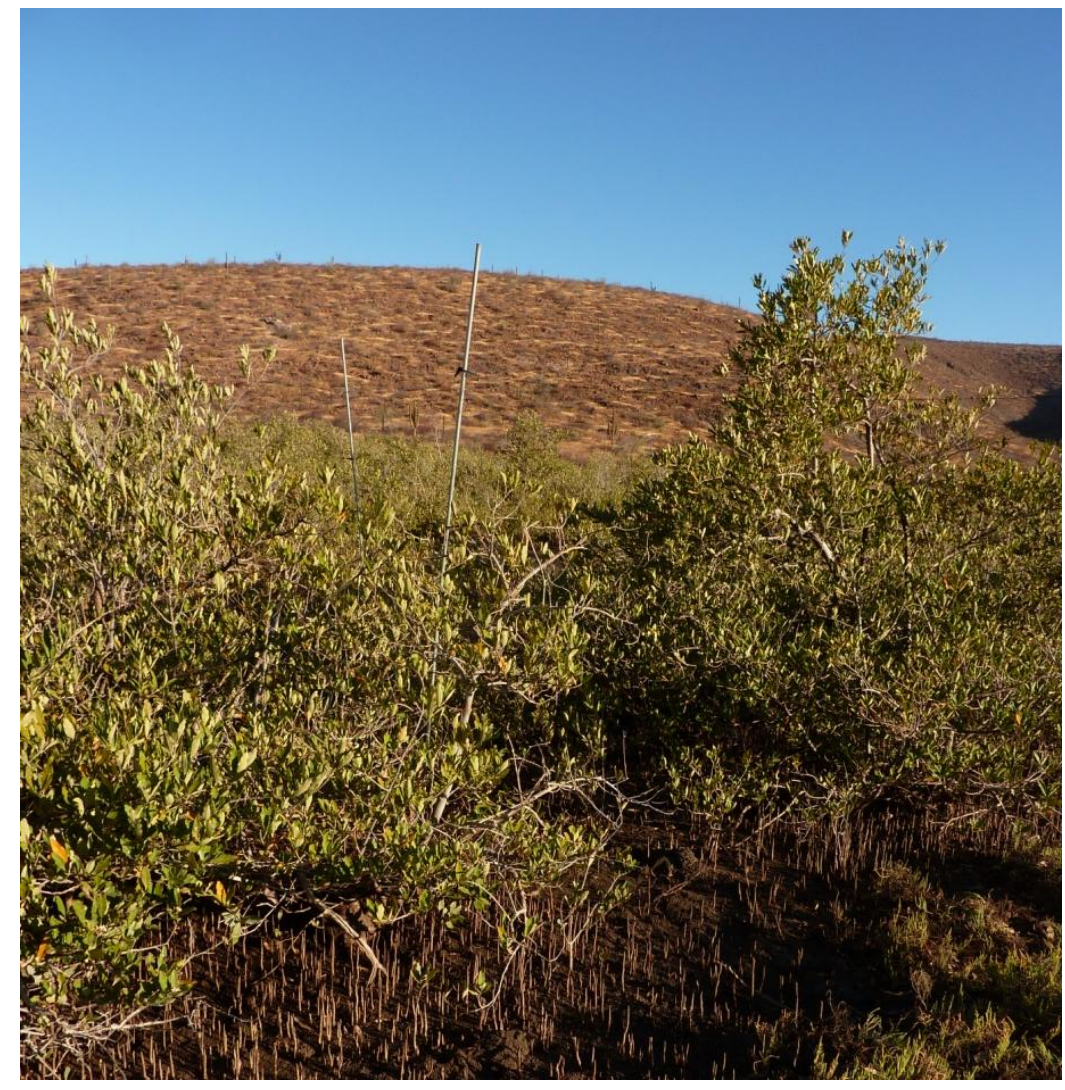

Fig. 11. Bahia Kino study area, Sonora, Mexico. 
Table 1. Area and perimeter of study areas and study sites in Baja California Sur and Sonora, Mexico. Straight-line distances (determined in ArcMap 9.3.1) between major study areas and minimum/maximum distances between study sites within a study area.

\begin{tabular}{|c|c|c|c|c|c|c|}
\hline $\begin{array}{l}\text { Major } \\
\text { Study } \\
\text { Area }\end{array}$ & $\begin{array}{l}\text { Study } \\
\text { Site } \\
\text { Names }\end{array}$ & $\begin{array}{l}\text { Total } \\
\text { Area } \\
\text { (ha) }\end{array}$ & $\begin{array}{l}\text { Total } \\
\text { Perimeter } \\
(\mathrm{km})\end{array}$ & $\begin{array}{l}\text { Max. Distance } \\
\text { Between Study } \\
\text { Sites }(\mathrm{km})\end{array}$ & $\begin{array}{c}\text { Min. } \\
\text { Distance } \\
\text { Between } \\
\text { Study Sites } \\
\quad(\mathrm{km})\end{array}$ & $\begin{array}{c}\text { Average } \\
\text { Distance } \\
\text { Between Study } \\
\text { Sites }(\mathrm{km})\end{array}$ \\
\hline \multirow[t]{6}{*}{$\mathrm{La} \mathrm{Paz}$} & & 40.48 & 21.04 & 19.42 & 0.91 & 5.72 \\
\hline & LP1 & 2.37 & 1.62 & & & \\
\hline & LP3 & 3.71 & 1.62 & & & \\
\hline & LP4 & 3.61 & 2.41 & & & \\
\hline & LP6 & 25.05 & 10.32 & & & \\
\hline & LP7 & 5.87 & 5.07 & & & \\
\hline \multirow[t]{3}{*}{$\begin{array}{l}\text { Magdalena } \\
\text { Bay }\end{array}$} & & 67.79 & 10.39 & 11.9 & 11.9 & 11.9 \\
\hline & MB1 & 25.87 & 7.1 & & & \\
\hline & MB3 & 41.91 & 3.29 & & & \\
\hline PALM & & 6.46 & 2.42 & -- & -- & -- \\
\hline \multirow[t]{6}{*}{ Mulege } & & 8.77 & 8.53 & 31.81 & 1.83 & 8.01 \\
\hline & MU2 & 1.41 & 1.92 & & & \\
\hline & MU3 & 0.35 & 0.73 & & & \\
\hline & MU4 & 3.21 & 2.01 & & & \\
\hline & MU5 & 2.92 & 1.94 & & & \\
\hline & MU6 & 0.88 & 1.93 & & & \\
\hline \multirow[t]{4}{*}{ San Lucas } & & 4.04 & 3.3 & 1.94 & 0.95 & 0.95 \\
\hline & SL1 & 0.17 & 0.17 & & & \\
\hline & SL2 & 1.74 & 1.26 & & & \\
\hline & SL3 & 2.12 & 1.87 & & & \\
\hline \multirow[t]{3}{*}{$\begin{array}{l}\text { Bahia } \\
\text { Kino }\end{array}$} & & 22.77 & 9.86 & 1.12 & 1.12 & 1.12 \\
\hline & BK1 & 0.26 & 0.68 & & & \\
\hline & BK2 & 22.52 & 9.18 & & & \\
\hline San Carlos & & 15.08 & 10.38 & -- & -- & -- \\
\hline
\end{tabular}


Table 1. Continued

\begin{tabular}{ccrrccc}
\hline $\begin{array}{c}\text { Major } \\
\text { Study } \\
\text { Area }\end{array}$ & $\begin{array}{c}\text { Study } \\
\text { Site } \\
\text { Names }\end{array}$ & $\begin{array}{c}\text { Total } \\
\text { Area } \\
\text { (ha) }\end{array}$ & $\begin{array}{c}\text { Total } \\
\text { Perimeter } \\
(\mathrm{km})\end{array}$ & $\begin{array}{c}\text { Max. Distance } \\
\text { Between Study } \\
\text { Sites }(\mathrm{km})\end{array}$ & $\begin{array}{c}\text { Min. } \\
\text { Distance } \\
\text { Between } \\
\text { Study Sites } \\
(\mathrm{km})\end{array}$ & $\begin{array}{c}\text { Average } \\
\text { Distance } \\
\text { Between Study } \\
\text { Sites (km) }\end{array}$ \\
\hline La Piedra & & 20.17 & 15.95 & 3.96 & 0.08 & 0.44 \\
& PA1 & 0.57 & 0.5 & & & \\
& PA2 & 1.49 & 6.25 & & & \\
& PA3 & 3.39 & 1.67 & & & \\
& PA4 & 8.59 & 5.11 & & & \\
& PA5 & 6.12 & 2.41 & & & \\
& & & & & & \\
Yavaros & & 16.11 & 10.32 & 9.4 & & \\
& YA1 & 4.1 & 2.45 & & & \\
& YA2 & 2.67 & 2.65 & & & \\
& YA3 & 1.97 & 1.46 & & & \\
& YA4 & 2.37 & 1.47 & & & \\
& YA5 & 4.99 & 2.29 & & & \\
\hline
\end{tabular}




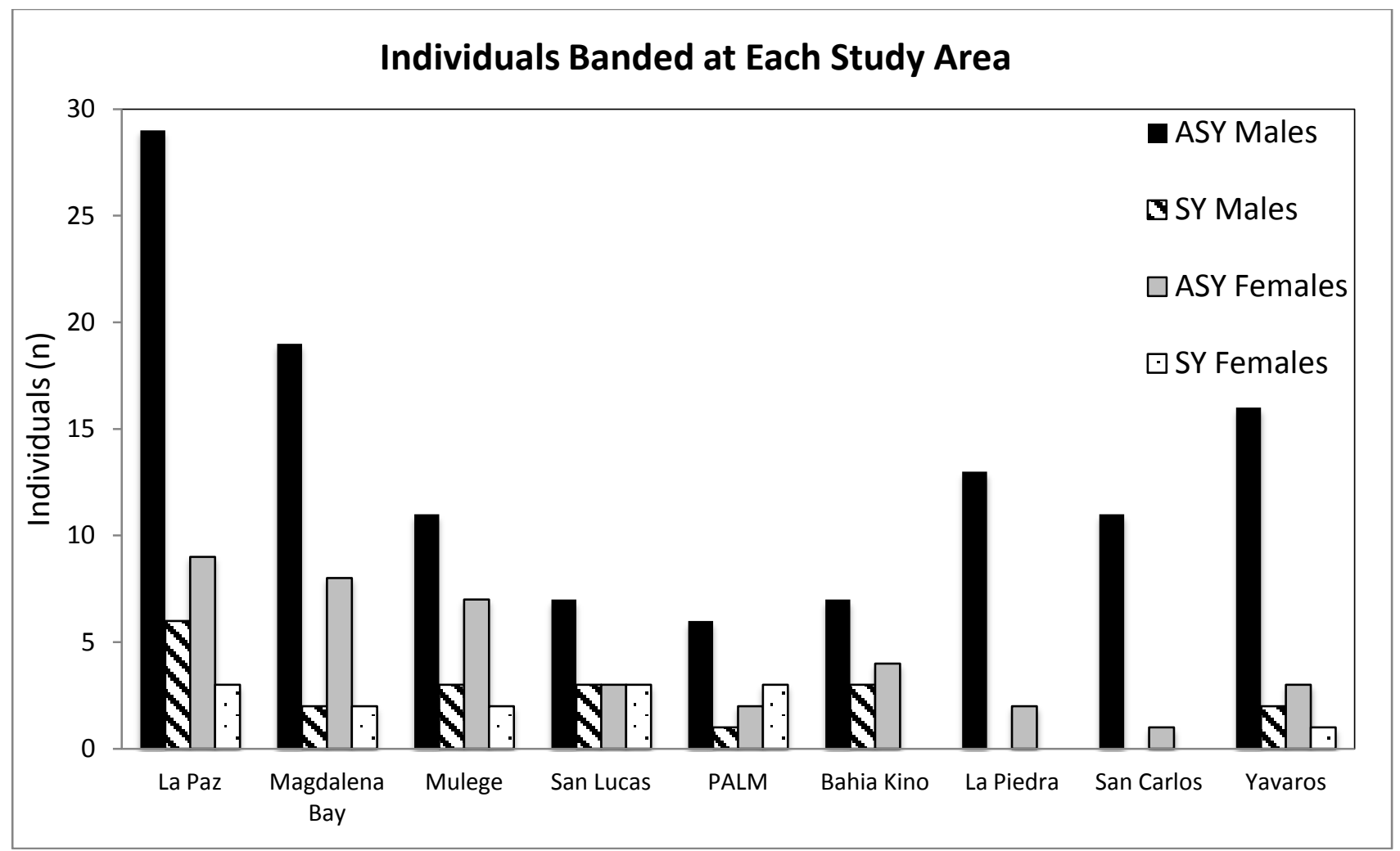

Fig. 12. Individuals banded at each study area divided by age class (after second year, ASY; second year, SY). Individuals from La Paz, Magdalena Bay, Mulegé, San Lucas and Puerto Adolfo López Mateos (PALM) study areas belong to $S$. p. castaneiceps. Individuals from Bahia Kino, La Piedra, San Carlos and Yavaros study areas are S. p. rhizophorae. 
Table 2. MANOVA table comparing morphometric measurements among subspecies (S. $p$. castaneiceps and S. p. rhizophorae), sex (male and female), and the interaction of subspecies and sex.

\begin{tabular}{lcccccc}
\hline & $\mathrm{dF}$ & Pillai & Approx. F & Num. $\mathrm{dF}$ & Den. $\mathrm{dF}$ & $\mathrm{P}$ \\
\hline Subspecies & 1 & 0.72 & 63.91 & 7 & 178 & $<0.001$ \\
Sex & 1 & 0.49 & 24.64 & 7 & 178 & $<0.001$ \\
Subspecies:Sex & 1 & 0.02 & 0.55 & 7 & 178 & 0.79 \\
Residuals & 184 & & & & & \\
\hline
\end{tabular}




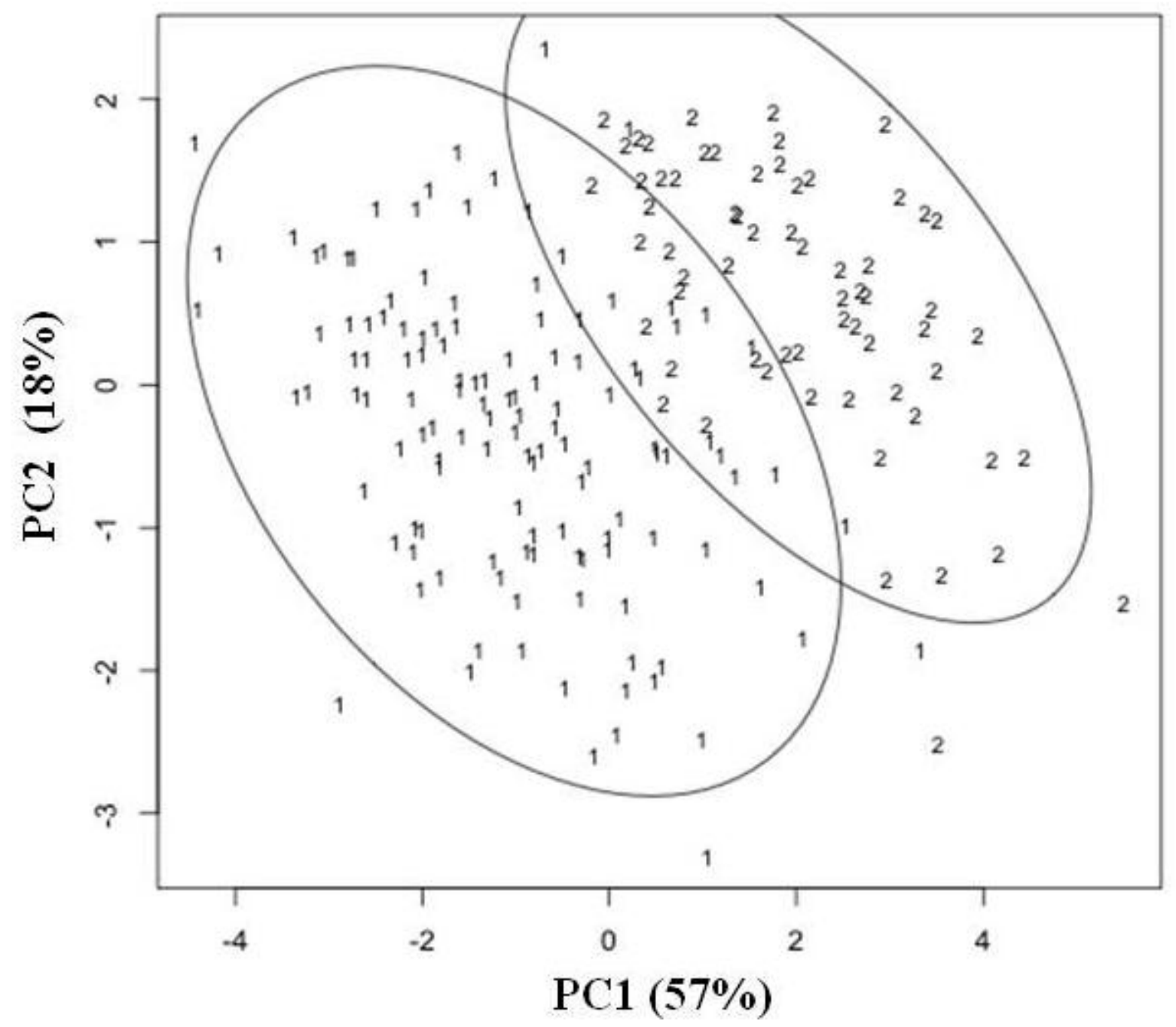

Fig. 13. Biplot of Principal Component Analysis (PCA) with 95\% confidence ellipses. 1 refers to $S$. p. castaneiceps and 2 refers to $S$. $p$. rhizophorae individuals. 
Table 3. Summary of biometrics measurements on each Mangrove Warbler subspecies separated by sex and age class. All measurements are averages in $\mathrm{mm}$, except weight which is $\mathrm{g}$. Standard deviation follows the averages $(\bar{x} \pm$ s.d).with range in parentheses below.

\begin{tabular}{|c|c|c|c|c|c|c|c|c|c|c|}
\hline Population & Sex & $\begin{array}{l}\text { Age } \\
\text { Class }\end{array}$ & n & & & Biom & tric Measur & ements & & \\
\hline \multirow{8}{*}{$\begin{array}{l}\text { S. } p \text {. } \\
\text { castaneiceps }\end{array}$} & & & & $\begin{array}{l}\text { Wing } \\
\text { Chord }\end{array}$ & $\begin{array}{c}\text { Bill } \\
\text { Length }\end{array}$ & $\begin{array}{c}\text { Bill } \\
\text { Depth }\end{array}$ & $\begin{array}{l}\text { Tarsus } \\
\text { Length }\end{array}$ & $\begin{array}{c}\text { Tail } \\
\text { Length }\end{array}$ & $\begin{array}{l}\text { Total } \\
\text { Length }\end{array}$ & Weight \\
\hline & & & 129 & $\begin{array}{c}64.32 \pm 2.60 \\
(57-69.5)\end{array}$ & $\begin{array}{c}11.21 \pm 0.43 \\
(9.8-12.2)\end{array}$ & $\begin{array}{c}3.87 \pm 0.31 \\
(3.1-4.5)\end{array}$ & $\begin{array}{c}21.78 \pm 0.63 \\
(20-24)\end{array}$ & $\begin{array}{c}50.94 \pm 2.13 \\
(45-55.3)\end{array}$ & $\begin{array}{c}116.81 \pm 3.36 \\
(110-127)\end{array}$ & $\begin{array}{c}11.68 \pm 0.95 \\
(8.3-14.2)\end{array}$ \\
\hline & Male & & 87 & $\begin{array}{l}65.60 \pm 1.90 \\
(60.5-69.5)\end{array}$ & $\begin{array}{c}11.23 \pm 0.46 \\
(9.8-12.2)\end{array}$ & $\begin{array}{c}3.89 \pm 0.31 \\
(3.1-4.5)\end{array}$ & $\begin{array}{c}21.92 \pm 0.65 \\
(20-24)\end{array}$ & $\begin{array}{c}51.61 \pm 1.96 \\
(48-55.3)\end{array}$ & $\begin{array}{c}117.92 \pm 3.06 \\
(110-127)\end{array}$ & $\begin{array}{l}11.89 \pm 0.78 \\
(10.1-14.1)\end{array}$ \\
\hline & & ASY & 72 & $\begin{array}{l}66.13 \pm 1.45 \\
(61.2-69.5)\end{array}$ & $\begin{array}{l}11.24 \pm 0.41 \\
(10.1-12.2)\end{array}$ & $\begin{array}{c}3.88 \pm 0.31 \\
(3.1-4.5)\end{array}$ & $\begin{array}{c}21.94 \pm 0.66 \\
(20-24)\end{array}$ & $\begin{array}{l}51.94 \pm 1.92 \\
(50.1-55.3)\end{array}$ & $\begin{array}{c}118.31 \pm 2.96 \\
(112-127)\end{array}$ & $\begin{array}{l}11.99 \pm 0.78 \\
(10.1-14.1)\end{array}$ \\
\hline & & SY & 15 & $\begin{array}{c}63.07 \pm 1.85 \\
(60.5-68)\end{array}$ & $\begin{array}{c}11.19 \pm 0.67 \\
(9.8-12.2)\end{array}$ & $\begin{array}{c}3.92 \pm 0.27 \\
(3.5-4.4)\end{array}$ & $\begin{array}{l}21.79 \pm 0.59 \\
(20.6-22.9)\end{array}$ & $\begin{array}{c}50.03 \pm 1.32 \\
(48-52)\end{array}$ & $\begin{array}{c}116.07 \pm 2.93 \\
(110-120)\end{array}$ & $\begin{array}{l}11.45 \pm 0.59 \\
(10.6-12.5)\end{array}$ \\
\hline & Female & & 42 & $\begin{array}{c}61.61 \pm 1.64 \\
(57-64.5)\end{array}$ & $\begin{array}{c}11.18 \pm 0.37 \\
(10.4-12)\end{array}$ & $\begin{array}{c}3.82 \pm 0.31 \\
(3.2-4.5)\end{array}$ & $\begin{array}{l}21.50 \pm 0.48 \\
(20.7-22.7)\end{array}$ & $\begin{array}{c}49.51 \pm 1.74 \\
(45-53)\end{array}$ & $\begin{array}{c}114.45 \pm 1.74 \\
(110-121)\end{array}$ & $\begin{array}{c}11.22 \pm 1.12 \\
(8.3-14.2)\end{array}$ \\
\hline & & ASY & 29 & $\begin{array}{l}62.29 \pm 1.12 \\
(60.5-64.5)\end{array}$ & $\begin{array}{c}11.15 \pm 0.36 \\
(10.4-12)\end{array}$ & $\begin{array}{c}3.84 \pm 0.33 \\
(3.3-4.5)\end{array}$ & $\begin{array}{l}21.51 \pm 0.49 \\
(20.8-22.7)\end{array}$ & $\begin{array}{c}50.02 \pm 1.43 \\
(47-53)\end{array}$ & $\begin{array}{c}115.32 \pm 2.50 \\
(110.8-121)\end{array}$ & $\begin{array}{c}11.26 \pm 1.20 \\
(8.3-14.2)\end{array}$ \\
\hline & & SY & 13 & $\begin{array}{c}60.15 \pm 1.66 \\
(57-63)\end{array}$ & $\begin{array}{l}11.25 \pm 0.40 \\
(10.4-11.9)\end{array}$ & $\begin{array}{c}3.75 \pm 0.28 \\
(3.2-4.1)\end{array}$ & $\begin{array}{l}21.48 \pm 0.49 \\
(20.7-22.1)\end{array}$ & $\begin{array}{c}48.28 \pm 1.87 \\
(45-52)\end{array}$ & $\begin{array}{c}112.34 \pm 1.98 \\
(110-116)\end{array}$ & $\begin{array}{c}11.14 \pm 0.94 \\
(9.9-13)\end{array}$ \\
\hline \multirow[t]{8}{*}{$\begin{array}{l}\text { S. } p . \\
\text { rhizophorae }\end{array}$} & & & 63 & $\begin{array}{c}62.37 \pm 2.27 \\
(56.2-66)\end{array}$ & $\begin{array}{c}10.40 \pm 0.47 \\
(9.2-11.3)\end{array}$ & $\begin{array}{c}3.25 \pm 0.16 \\
(2.9-3.8)\end{array}$ & $\begin{array}{l}20.76 \pm 0.58 \\
(19.8-21.8)\end{array}$ & $\begin{array}{c}49.98 \pm 2.01 \\
(44.8-53)\end{array}$ & $\begin{array}{c}112.0 \pm 3.44 \\
(103-119)\end{array}$ & $\begin{array}{c}10.02 \pm 0.71 \\
(8.3-11.7)\end{array}$ \\
\hline & Male & & 52 & $\begin{array}{c}63.1 \pm 1.63 \\
(59-66)\end{array}$ & $\begin{array}{c}10.41 \pm 0.46 \\
(9.2-11.3)\end{array}$ & $\begin{array}{c}3.25 \pm 0.16 \\
(2.9-3.8)\end{array}$ & $\begin{array}{l}20.83 \pm 0.59 \\
(19.8-21.8)\end{array}$ & $\begin{array}{c}50.51 \pm 1.57 \\
(46-53)\end{array}$ & $\begin{array}{c}112.75 \pm 2.80 \\
(106.3-119)\end{array}$ & $\begin{array}{c}10.13 \pm 0.66 \\
(8.3-11.7)\end{array}$ \\
\hline & & ASY & 47 & $\begin{array}{c}63.07 \pm 1.44 \\
(59-66)\end{array}$ & $\begin{array}{c}10.46 \pm 0.42 \\
(9.2-11.3)\end{array}$ & $\begin{array}{c}3.26 \pm 0.16 \\
(2.9-3.8)\end{array}$ & $\begin{array}{l}20.95 \pm 0.54 \\
(19.8-21.8)\end{array}$ & $\begin{array}{c}50.57 \pm 1.78 \\
(46-53)\end{array}$ & $\begin{array}{c}112.61 \pm 2.75 \\
(106.3-119)\end{array}$ & $\begin{array}{c}10.27 \pm 0.58 \\
(8.3-11.4)\end{array}$ \\
\hline & & SY & 5 & $\begin{array}{c}61.12 \pm 2.19 \\
(59-64.5)\end{array}$ & $\begin{array}{c}10.26 \pm 0.32 \\
(10-10.8)\end{array}$ & $\begin{array}{c}3.18 \pm 0.08 \\
(3.1-3.3)\end{array}$ & $\begin{array}{l}20.62 \pm 0.85 \\
(19.8-21.8)\end{array}$ & $\begin{array}{c}50.0 \pm 1.51 \\
(48.6-52.5)\end{array}$ & $\begin{array}{c}111.56 \pm 3.20 \\
(109-117.1)\end{array}$ & $\begin{array}{c}10.12 \pm 0.99 \\
(9-11.7)\end{array}$ \\
\hline & Female & & 11 & $\begin{array}{l}58.91 \pm 1.56 \\
(56.2-61.9)\end{array}$ & $\begin{array}{c}10.32 \pm 0.51 \\
(9.3-11.2)\end{array}$ & $\begin{array}{c}3.28 \pm 0.21 \\
(3-3.8)\end{array}$ & $\begin{array}{c}20.45 \pm 0.44 \\
(20-21.2)\end{array}$ & $\begin{array}{c}47.23 \pm 1.82 \\
(44.8-50)\end{array}$ & $\begin{array}{c}108.09 \pm 3.92 \\
(103-116)\end{array}$ & $\begin{array}{c}9.51 \pm 0.72 \\
(8.4-11)\end{array}$ \\
\hline & & ASY & 10 & $\begin{array}{l}58.97 \pm 1.63 \\
(56.2-61.9)\end{array}$ & $\begin{array}{c}10.23 \pm 0.44 \\
(9.3-10.8)\end{array}$ & $\begin{array}{c}3.3 \pm 0.21 \\
(3-3.8)\end{array}$ & $\begin{array}{c}20.37 \pm 0.38 \\
(20-21)\end{array}$ & $\begin{array}{c}47.24 \pm 1.93 \\
(44.8-50)\end{array}$ & $\begin{array}{c}107.99 \pm 4.15 \\
(103-116)\end{array}$ & $\begin{array}{c}9.5 \pm 0.76 \\
(8.4-11)\end{array}$ \\
\hline & & SY & 1 & & & & & & & \\
\hline & & & & 58.3 & 11.2 & 3.1 & 21.2 & 47.1 & 109 & 9.6 \\
\hline \multirow[t]{3}{*}{ Overall } & & & 192 & $\begin{array}{l}63.68 \pm 2.66 \\
(56.2-69.5)\end{array}$ & $\begin{array}{c}10.95 \pm 0.59 \\
(9.2-12.2)\end{array}$ & $\begin{array}{c}3.67 \pm 0.39 \\
(2.9-4.5)\end{array}$ & $\begin{array}{c}21.45 \pm 0.78 \\
(19.8-24)\end{array}$ & $\begin{array}{l}50.63 \pm 2.13 \\
(44.8-55.3)\end{array}$ & $\begin{array}{c}115.24 \pm 4.06 \\
(103-127)\end{array}$ & $\begin{array}{c}11.13 \pm 1.17 \\
(8.3-14.2)\end{array}$ \\
\hline & Male & & 139 & $\begin{array}{c}64.66 \pm 2.17 \\
(59-69.5)\end{array}$ & $\begin{array}{c}10.92 \pm 0.61 \\
(9.2-12.2)\end{array}$ & $\begin{array}{c}3.65 \pm 0.40 \\
(2.9-4.5)\end{array}$ & $\begin{array}{c}21.51 \pm 0.82 \\
(19.8-24)\end{array}$ & $\begin{array}{c}51.20 \pm 1.89 \\
(46-55.3)\end{array}$ & $\begin{array}{c}115.99 \pm 3.88 \\
(106.3-127)\end{array}$ & $\begin{array}{c}11.23 \pm 1.13 \\
(8.3-14.1)\end{array}$ \\
\hline & Female & & 53 & $\begin{array}{l}61.04 \pm 1.96 \\
(56.2-64.5)\end{array}$ & $\begin{array}{c}11.00 \pm 0.53 \\
(9.3-12)\end{array}$ & $\begin{array}{c}3.71 \pm 0.37 \\
(3-4.5)\end{array}$ & $\begin{array}{c}21.28 \pm 0.64 \\
(20-22.7)\end{array}$ & $\begin{array}{c}49.06 \pm 1.96 \\
(44.8-53)\end{array}$ & $\begin{array}{c}113.20 \pm 3.89 \\
(103-121)\end{array}$ & $\begin{array}{c}10.87 \pm 1.26 \\
(8.3-14.2)\end{array}$ \\
\hline
\end{tabular}


Table 4. Summary of variance explained by Principal Component Analysis (PCA) comparing biometrics of $S$. p. castaneiceps and $S$. p. rhizophorae.

\begin{tabular}{lccccccc}
\hline & PC1 & PC2 & PC3 & PC4 & PC5 & PC6 & PC7 \\
\hline $\begin{array}{l}\text { Standard } \\
\text { Deviation }\end{array}$ & 1.99 & 1.11 & 0.72 & 0.68 & 0.6 & 0.51 & 0.46 \\
$\begin{array}{l}\text { Proportion of } \\
\text { Variance }\end{array}$ & 0.57 & 0.18 & 0.07 & 0.07 & 0.05 & 0.04 & 0.03 \\
$\begin{array}{l}\text { Cumulative } \\
\text { Proportion }\end{array}$ & 0.57 & 0.74 & 0.82 & 0.88 & 0.93 & 0.97 & 1.00 \\
\hline
\end{tabular}


Table 5. Factor loading (correlation coefficients between factors and variables) of the Principal Component Analysis (PCA) of the seven morphological traits used to evaluate the biometric variation between Mangrove Warblers. Only the first two principal components are shown.

\begin{tabular}{cccccccc}
\hline & $\begin{array}{c}\text { Wing } \\
\text { Chord }\end{array}$ & $\begin{array}{c}\text { Bill } \\
\text { Length }\end{array}$ & $\begin{array}{c}\text { Bill } \\
\text { Depth }\end{array}$ & $\begin{array}{c}\text { Tarsus } \\
\text { Length }\end{array}$ & $\begin{array}{c}\text { Tail } \\
\text { Length }\end{array}$ & $\begin{array}{c}\text { Total } \\
\text { Length }\end{array}$ & Weight \\
\hline PC1 & -0.80 & -0.63 & -0.70 & -0.77 & -0.63 & -0.87 & -0.83 \\
PC2 & 0.41 & -0.49 & -0.49 & -0.21 & 0.69 & 0.20 & -0.14 \\
\hline
\end{tabular}


Table 6. MANOVA table comparing morphometric measurements among study areas within subspecies. S.p.c=Setophaga petechia castaneiceps, S.p.r=S. p. rhizophorae.

\begin{tabular}{lcccccc}
\hline & $\mathrm{dF}$ & Pillai & Approx. F & Num. dF & Den. dF & $\mathrm{P}$ \\
\hline $\begin{array}{l}\text { S.p.c by study area } \\
\text { Residuals }\end{array}$ & 5 & 0.52 & 1.95 & 35 & 595 & 0.001 \\
$\begin{array}{l}\text { S.p.r. by study area } \\
\text { Residuals }\end{array}$ & 121 & & & & & \\
\hline
\end{tabular}


Table 7. ANOVA table comparing morphometric measurements among the five study areas (La Paz, Magdalena Bay, Puerto Adolfo López Mateos, Mulegé, and San Lucas) of S. p. castaneiceps in Baja California Sur, Mexico.

\begin{tabular}{lrrrrr}
\hline \multicolumn{1}{c}{ Source } & DF & Type III SS & Mean Square & F Value & Pr $>$ F \\
\hline Wing Chord & 4 & 36.73 & 9.18 & 1.36 & 0.25 \\
Bill Length & 4 & 2.87 & 0.72 & 4.14 & $<0.01$ \\
Bill Depth & 4 & 0.31 & 0.08 & 0.77 & 0.55 \\
Tarsus Length & 4 & 4.10 & 1.02 & 2.76 & 0.03 \\
Tail Length & 4 & 36.24 & 9.06 & 1.96 & 0.10 \\
Total Length & 4 & 129.83 & 32.46 & 2.85 & 0.03 \\
Weight & 4 & 14.31 & 3.58 & 4.01 & $<0.01$ \\
\hline
\end{tabular}


Table 8. ANOVA post-hoc contrasts comparing bill length measurements among study areas of S. p. castaneiceps. The mean bill length of one study area was compared to the mean bill length of all other study areas. 1= La Paz, 2= Magdalena Bay, 3= Mulegé, 4=San Lucas, 5= Puerto Adolfo López Mateos (PALM), 2, 5= Magdalena Bay and PALM combined.

\begin{tabular}{crrrrr}
\hline Contrast & DF & Contrast SS & Mean Square & F Value & \multicolumn{1}{c}{ Pr $>$ F } \\
\hline 1 vs. $2,3,4,5$ & 1 & 0.88 & 0.88 & 5.09 & 0.03 \\
2 vs. 1,3,4,5 & 1 & 0.31 & 0.31 & 1.82 & 0.18 \\
3 vs. 1,2,4,5 & 1 & 0.04 & 0.04 & 0.26 & 0.61 \\
4 vs. 1,2,3,5 & 1 & 1.35 & 1.35 & 7.78 & $<0.01$ \\
5 vs. 1,2,3,4 & 1 & 1.03 & 1.03 & 5.93 & 0.02 \\
2,5 vs. $1,3,4$ & 1 & 1.92 & 1.92 & 11.12 & 0.001 \\
\hline
\end{tabular}




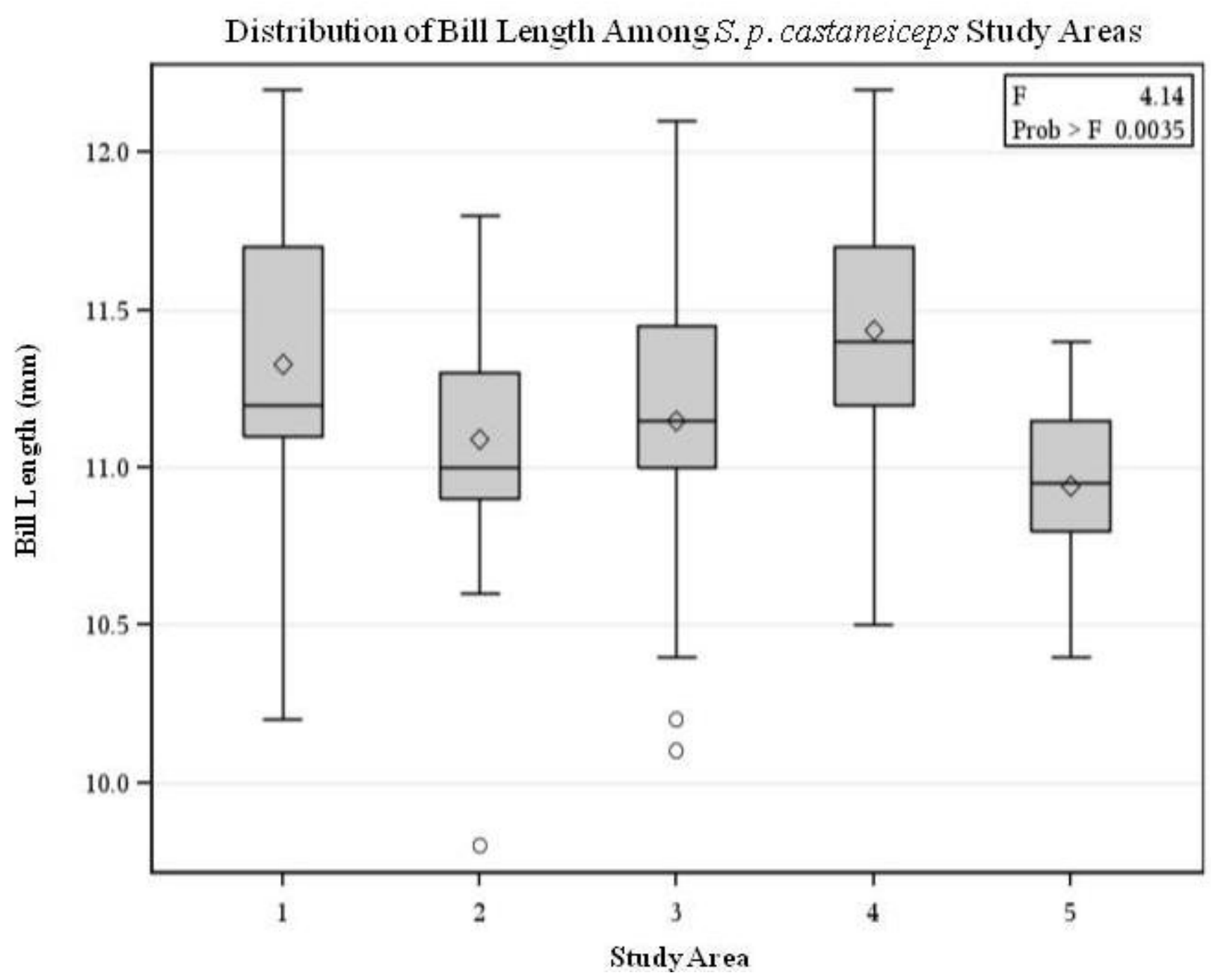

Fig. 14. Boxplot of bill lengths (mm) of S. p. castaneiceps among study areas in Baja California Sur, Mexico. 1= La Paz ( $\mathrm{n}=47), 2=$ Magdalena Bay $(\mathrm{n}=27), 3=$ Mulegé $(\mathrm{n}=24), 4=$ San Lucas $(\mathrm{n}=17)$, and 5= Puerto Adolfo López Mateos (PALM) $(\mathrm{n}=12)$. 
Table 9. ANOVA post-hoc contrasts comparing tarsus length measurements among study areas of S. p. castaneiceps. The mean tarsus length of one study area was compared to the mean tarsus length of all other study areas. $1=\mathrm{La} \mathrm{Paz}, 2=$ Magdalena Bay, $3=$ Mulegé, $4=$ San Lucas, 5= Puerto Adolfo López Mateos (PALM), 2, 5= Magdalena Bay and PALM combined.

\begin{tabular}{lrrrrr}
\hline Contrast & DF & \multicolumn{1}{c}{ Contrast SS } & Mean Square & F Value & Pr > F \\
\hline 1 vs. $2,3,4,5$ & 1 & 0.63 & 0.63 & 1.69 & 0.20 \\
2 vs. $1,3,4,5$ & 1 & 1.75 & 1.75 & 4.73 & 0.03 \\
3 vs. $1,2,4,5$ & 1 & 0.59 & 0.59 & 1.60 & 0.21 \\
4 vs. $1,2,3,5$ & 1 & 1.96 & 1.96 & 5.30 & 0.02 \\
5 vs. $1,2,3,4$ & 1 & 0.12 & 0.12 & 0.33 & 0.57 \\
2,5 vs. $1,3,4$ & 1 & 1.65 & 1.65 & 4.46 & 0.04 \\
\hline
\end{tabular}




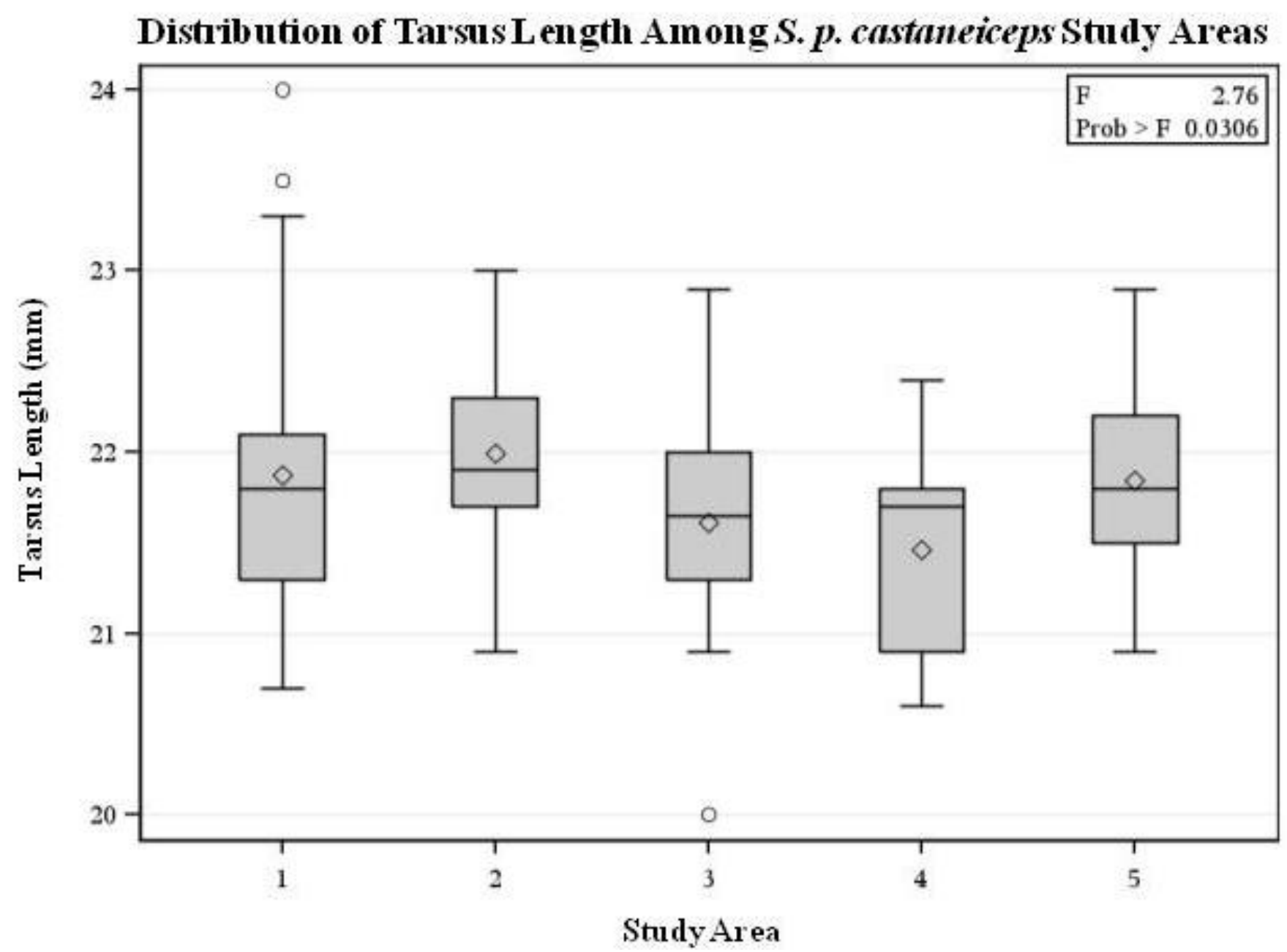

Fig. 15. Boxplot of tarsus lengths $(\mathrm{mm})$ of $S$. p. castaneiceps among study areas in Baja California Sur, Mexico. 1= La Paz ( $\mathrm{n}=47)$, 2= Magdalena Bay ( $\mathrm{n}=27), 3=$ Mulegé (n=24), 4=San Lucas $(\mathrm{n}=17)$, and 5= Puerto Adolfo López Mateos (PALM) $(\mathrm{n}=12)$. 
Table 10. ANOVA post-hoc contrasts comparing tail length measurements among study areas of S. p. castaneiceps. The mean tail length of one study area was compared to the mean tail length of all other study areas. 1= La Paz, 2= Magdalena Bay, 3= Mulegé, 4=San Lucas, 5= Puerto Adolfo López Mateos (PALM), 2, 5= Magdalena Bay and PALM combined.

\begin{tabular}{crrrrr}
\hline Contrast & DF & Contrast SS & Mean Square & F Value & Pr $>$ F \\
\hline 1 vs. $2,3,4,5$ & 1 & 0.34 & 0.34 & 0.07 & 0.79 \\
2 vs. $1,3,4,5$ & 1 & 34.56 & 34.56 & 7.48 & $<0.01$ \\
3 vs. $1,2,4,5$ & 1 & 2.03 & 2.03 & 0.44 & 0.51 \\
4 vs. $1,2,3,5$ & 1 & 5.70 & 5.70 & 1.23 & 0.27 \\
5 vs. $1,2,3,4$ & 1 & 0.61 & 0.61 & 0.13 & 0.72 \\
2,5 vs. $1,3,4$ & 1 & 11.76 & 11.76 & 2.55 & 0.11 \\
\hline
\end{tabular}


Distribution of Tail L ength Among S. p. castaneiceps Study Areas

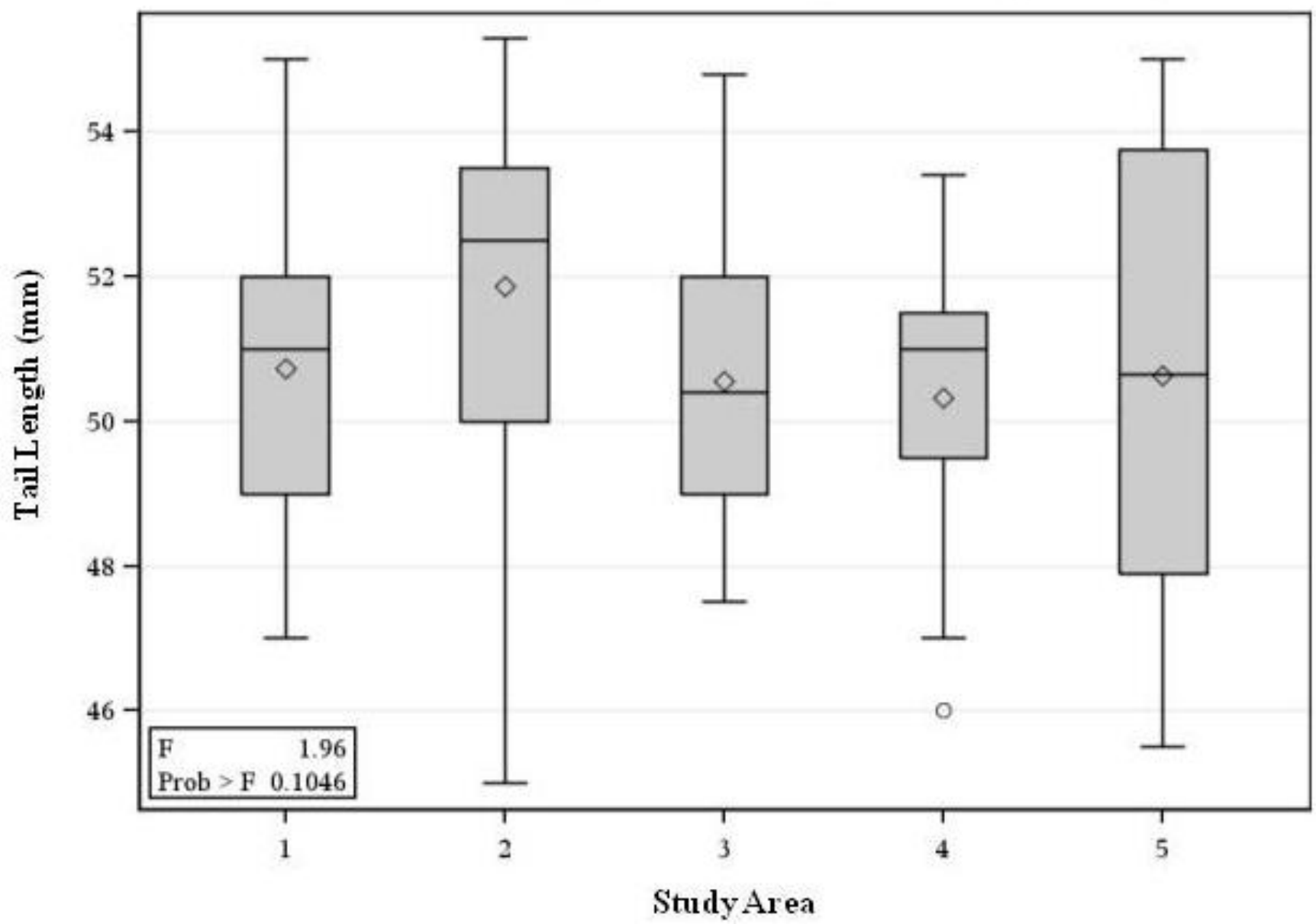

Fig. 16. Boxplot of tail lengths (mm) of S. p. castaneiceps among study areas in Baja California

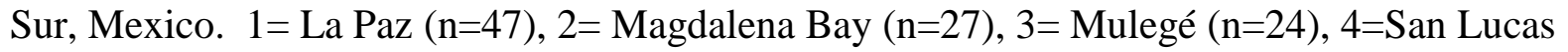
$(\mathrm{n}=17)$, and 5= Puerto Adolfo López Mateos (PALM) $(\mathrm{n}=12)$. 
Table 11. ANOVA post-hoc contrasts comparing total length measurements among study areas of $S$. p. castaneiceps. The mean total length of one study area was compared to the mean total length of all other study areas. 1= La Paz, 2= Magdalena Bay, 3= Mulegé, 4=San Lucas, 5= Puerto Adolfo López Mateos (PALM), 2, 5= Magdalena Bay and PALM combined.

\begin{tabular}{rrrrrr}
\hline Contrast & DF & Contrast SS & Mean Square & F Value & Pr $>$ F \\
\hline 1 vs. $2,3,4,5$ & 1 & 29.28 & 29.28 & 2.57 & 0.11 \\
2 vs. $1,3,4,5$ & 1 & 84.78 & 84.78 & 7.45 & $<0.01$ \\
3 vs. $1,2,4,5$ & 1 & 22.53 & 22.53 & 1.98 & 0.16 \\
4 vs. $1,2,3,5$ & 1 & 6.71 & 6.71 & 0.59 & 0.44 \\
5 vs. $1,2,3,4$ & 1 & 6.02 & 6.02 & 0.53 & 0.47 \\
2,5 vs. $1,3,4$ & 1 & 80.16 & 80.16 & 7.04 & $<0.01$ \\
\hline
\end{tabular}


Distribution of Total Length Among S. p. castaneiceps Study Areas

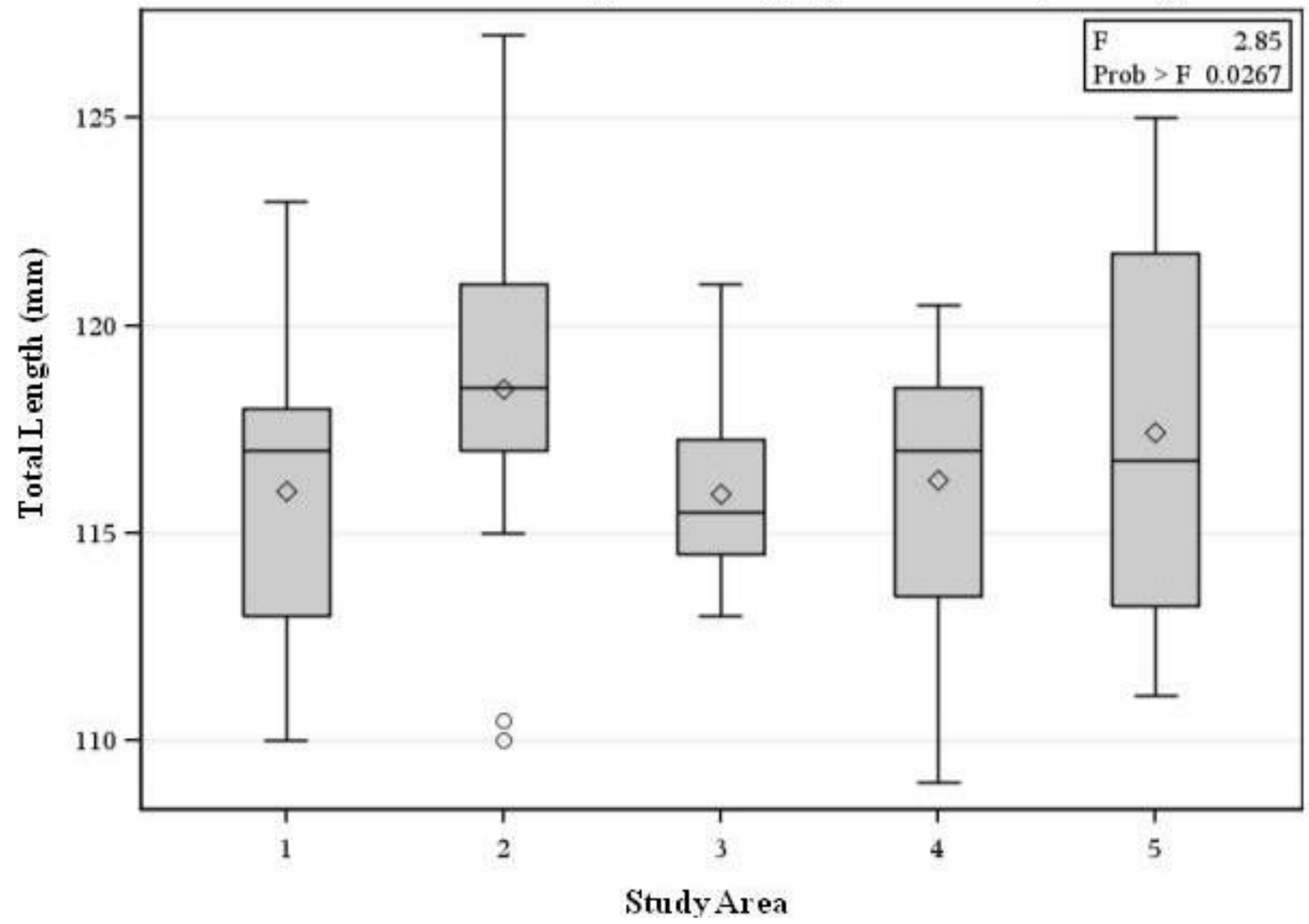

Fig. 17. Boxplot of total lengths (mm) of S. p. castaneiceps among study areas in Baja California Sur, Mexico. 1= La Paz (n=47), 2= Magdalena Bay ( $n=27), 3=$ Mulegé ( $=24), 4=$ San Lucas $(n=17)$, and 5= Puerto Adolfo López Mateos (PALM) $(n=12)$. 
Table 12. ANOVA post-hoc contrasts comparing weight measurements among study areas of $S$. p. castaneiceps. The mean weight of one study area was compared to the mean weight of all other study areas. 1= La Paz, 2= Magdalena Bay, 3= Mulegé, 4=San Lucas, 5= Puerto Adolfo López Mateos (PALM), 2, 5= Magdalena Bay and PALM combined.

\begin{tabular}{rrrrrr}
\hline Contrast & DF & Contrast SS & Mean Square & F Value & \multicolumn{1}{c}{ Pr $>$ F } \\
\hline 1 vs. $2,3,4,5$ & 1 & 10.54 & 10.54 & 11.82 & $<0.001$ \\
2 vs. $1,3,4,5$ & 1 & 2.82 & 2.82 & 3.16 & 0.08 \\
3 vs. 1,2,4,5 & 1 & 0.25 & 0.25 & 0.28 & 0.60 \\
4 vs. 1,2,3,5 & 1 & 0.31 & 0.31 & 0.35 & 0.56 \\
5 vs. $1,2,3,4$ & 1 & 2.66 & 2.66 & 2.98 & 0.09 \\
2,5 vs. $1,3,4$ & 1 & 7.76 & 7.76 & 8.70 & $<0.01$ \\
\hline
\end{tabular}




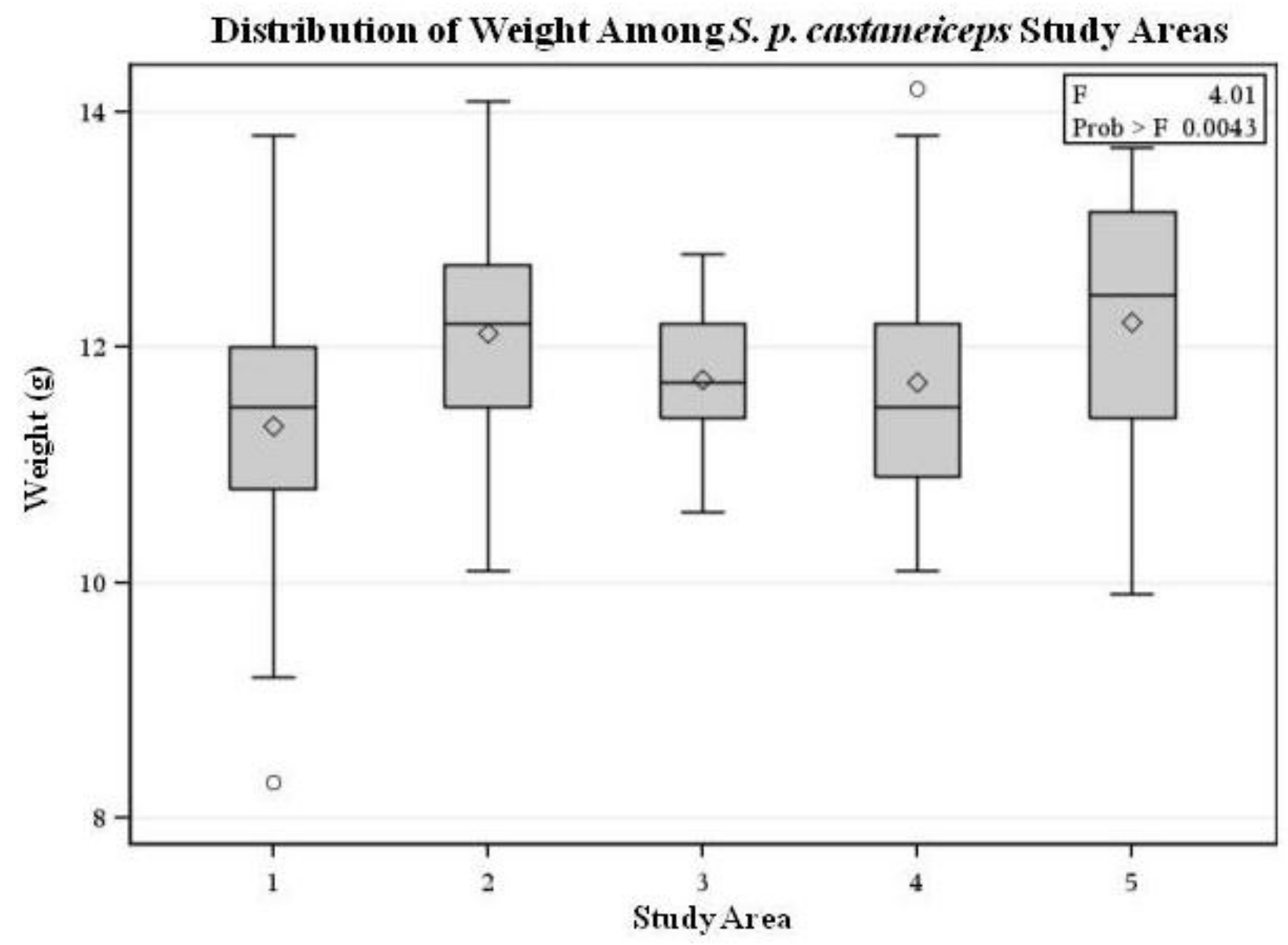

Fig. 18. Boxplot of weight (g) of S. p. castaneiceps among study areas in Baja California Sur, Mexico. 1= La Paz (n=47), 2= Magdalena Bay (n=27), 3= Mulegé (n=24), 4=San Lucas (n=17), and 5= Puerto Adolfo López Mateos (PALM) $(n=12)$. 
Table 13. ANOVA table comparing morphometric measurements among the four study areas (Bahia Kino, Yavaros, San Carlos, and La Piedra) of S. p. rhizophorae in Sonora, Mexico.

\begin{tabular}{lrrrrr}
\hline \multicolumn{1}{c}{ Source } & DF & Type III SS & Mean Square & F Value & \multicolumn{1}{c}{$\operatorname{Pr}>$ F } \\
\hline Wing Chord & 3 & 75.10 & 25.03 & 6.13 & $<0.01$ \\
Bill Length & 3 & 0.15 & 0.05 & 0.22 & 0.88 \\
Bill Depth & 3 & 0.02 & 0.01 & 0.26 & 0.85 \\
Tarsus Length & 3 & 2.03 & 0.68 & 2.07 & 0.11 \\
Tail Length & 3 & 68.34 & 22.78 & 7.80 & $<0.001$ \\
Total Length & 3 & 200.40 & 66.80 & 7.58 & $<0.001$ \\
Weight & 3 & 5.63 & 1.88 & 4.02 & 0.01 \\
\hline
\end{tabular}


Table 14. ANOVA post-hoc contrasts comparing wing chord measurements among study areas of $S$. p. rhizophorae. The mean wing chord of one study area was compared to the mean wing chord of all other study areas. $1=$ San Carlos, $2=$ Bahia Kino, 3= La Piedra, 4=Yavaros.

\begin{tabular}{rrrrrr}
\hline Contrast & DF & Contrast SS & Mean Square & F Value & \multicolumn{1}{c}{$\operatorname{Pr}>\mathrm{F}$} \\
\hline 1 vs. $2,3,4$ & 1 & 33.00 & 33.00 & 8.08 & $<0.01$ \\
2 vs. $1,3,4$ & 1 & 68.75 & 68.75 & 16.84 & $<0.001$ \\
3 vs. $1,2,4$ & 1 & 1.46 & 1.46 & 0.36 & 0.55 \\
4 vs. $1,2,3$ & 1 & 1.06 & 1.06 & 0.26 & 0.61 \\
\hline
\end{tabular}




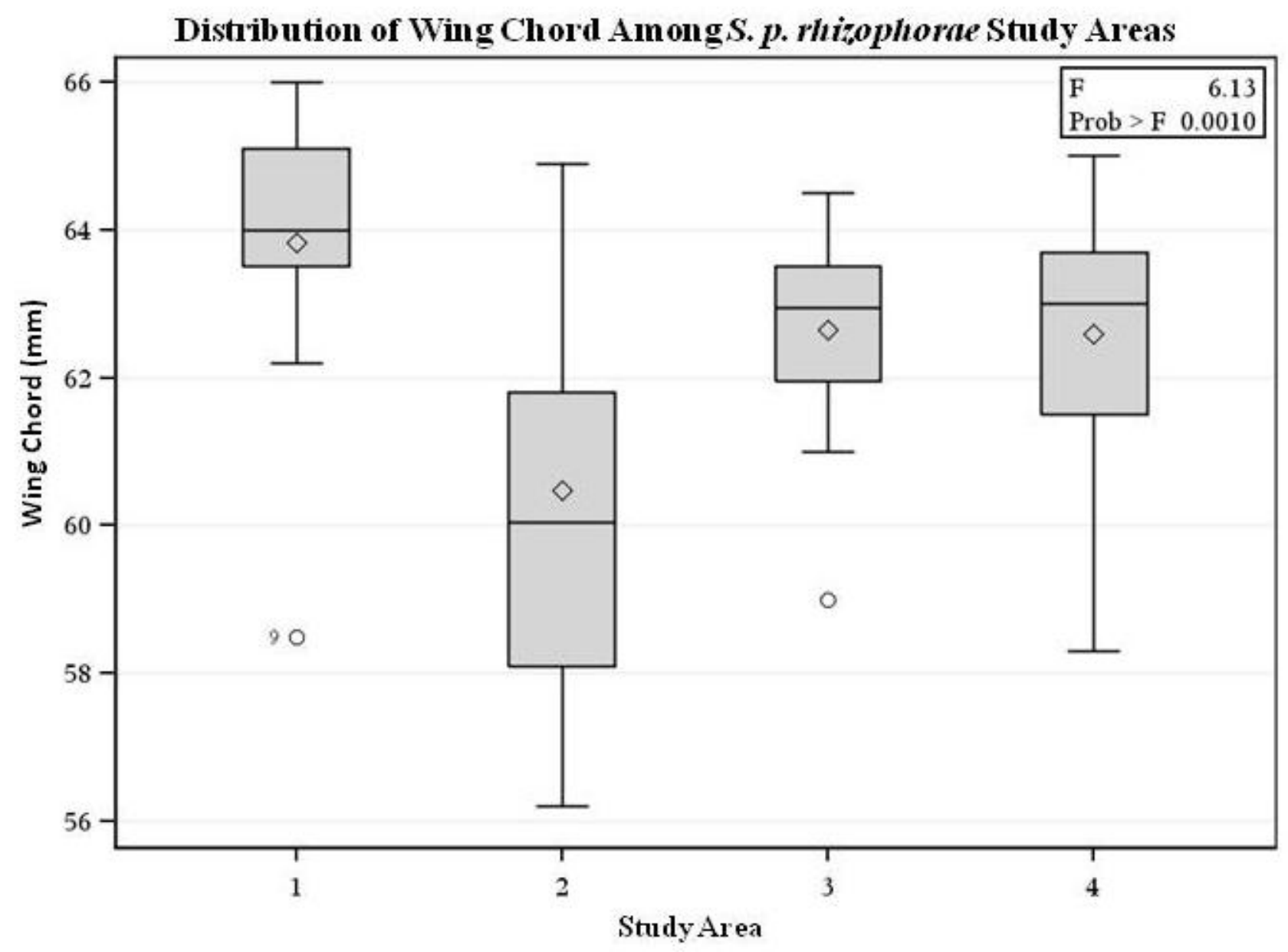

Fig. 19. Boxplot of wing chord (mm) of S. p. rhizophorae among study areas in Sonora, Mexico. $1=$ San Carlos $(n=11), 2=$ Bahia Kino $(n=14), 3=$ La Piedra $(n=16), 4=$ Yavaros $(n=23)$. 
Table 15. ANOVA post-hoc contrasts comparing tarsus length measurements among study areas of $S$. p. rhizophorae. The mean tarsus length of one study area was compared to the mean tarsus length of all other study areas. $1=$ San Carlos, $2=$ Bahia Kino, $3=$ La Piedra, 4=Yavaros.

\begin{tabular}{lrrrrr}
\hline \multicolumn{1}{c}{ Contrast } & DF & \multicolumn{1}{c}{ Contrast SS } & Mean Square & F Value & \multicolumn{1}{c}{$\operatorname{Pr}>$ F } \\
\hline 1 vs. $2,3,4$ & 1 & 0.04 & 0.04 & 0.11 & 0.74 \\
2 vs. $1,3,4$ & 1 & 0.16 & 0.16 & 0.49 & 0.49 \\
3 vs. $1,2,4$ & 1 & 0.37 & 0.37 & 1.12 & 0.29 \\
4 vs. $1,2,3$ & 1 & 1.91 & 1.91 & 5.84 & 0.02 \\
\hline
\end{tabular}


Distribution of Tarsus Length Among S. p. rhitophorae Study Areas

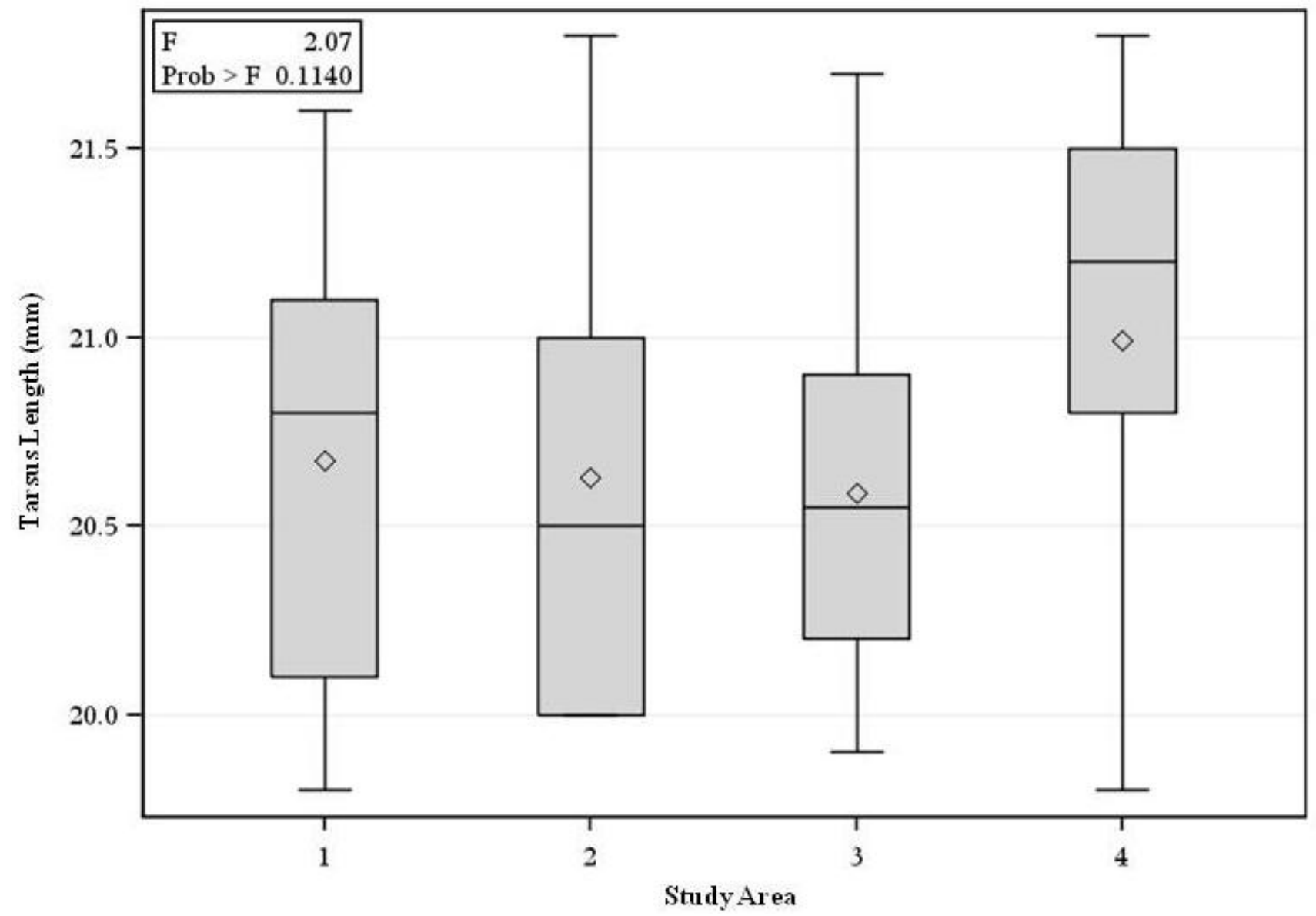

Fig. 20. Boxplot of tarsus length (mm) of S. p. rhizophorae among study areas in Sonora, Mexico. 1= San Carlos ( $\mathrm{n}=11), 2=$ Bahia Kino ( $\mathrm{n}=14), 3=$ La Piedra $(\mathrm{n}=16), 4=$ Yavaros ( $\mathrm{n}=23)$. 
Table 16. ANOVA post-hoc contrasts comparing tail length measurements among study areas of S. p. rhizophorae. The mean tail length of one study area was compared to the mean tail length of all other study areas. $1=$ San Carlos, $2=$ Bahia Kino, $3=$ La Piedra, $4=$ Yavaros.

\begin{tabular}{lrrrrr}
\hline Contrast & DF & \multicolumn{1}{c}{ Contrast SS } & Mean Square & F Value & \multicolumn{1}{l}{ Pr > F } \\
\hline 1 vs. $2,3,4$ & 1 & 10.54 & 10.54 & 3.61 & 0.06 \\
2 vs. $1,3,4$ & 1 & 66.72 & 66.72 & 22.85 & $<.0001$ \\
3 vs. $1,2,4$ & 1 & 3.58 & 3.58 & 1.22 & 0.27 \\
4 vs. $1,2,3$ & 1 & 10.87 & 10.87 & 3.72 & 0.06 \\
\hline
\end{tabular}


Distribution of Tail Length Among S. p. rhizophorae Study Areas

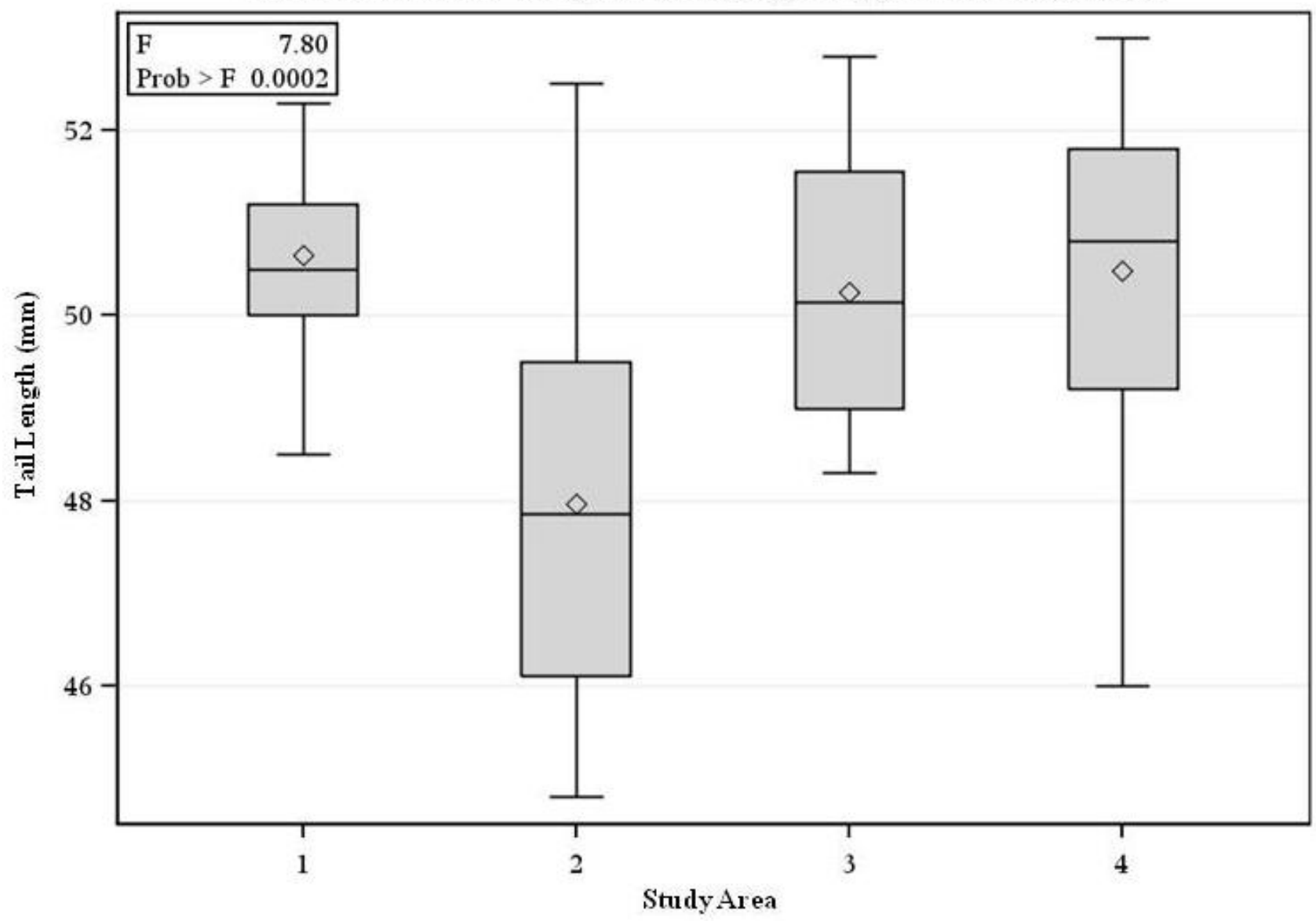

Fig. 21. Boxplot of tail length (mm) of $S$. p. rhizophorae among study areas in Sonora, Mexico. $1=$ San Carlos $(n=11), 2=$ Bahia Kino $(n=14), 3=$ La Piedra $(n=16), 4=$ Yavaros $(n=23)$. 
Table 17. ANOVA post-hoc contrasts comparing total length measurements among study areas of S. p. rhizophorae. The mean total length of one study area was compared to the mean total length of all other study areas. 1= San Carlos, 2= Bahia Kino, 3= La Piedra, 4=Yavaros.

\begin{tabular}{lrrrrr}
\hline Contrast & DF & \multicolumn{1}{c}{ Contrast SS } & Mean Square & F Value & \multicolumn{1}{c}{ Pr $>$ F } \\
\hline 1 vs. $2,3,4$ & 1 & 107.95 & 107.95 & 12.25 & $<0.001$ \\
2 vs. $1,3,4$ & 1 & 164.62 & 164.62 & 18.69 & $<.0001$ \\
3 vs. $1,2,4$ & 1 & 7.10 & 7.10 & 0.81 & 0.37 \\
4 vs. $1,2,3$ & 1 & 1.45 & 1.45 & 0.16 & 0.69 \\
\hline
\end{tabular}


Distribution of Total Length Among S. p. rhitophorae Study Areas

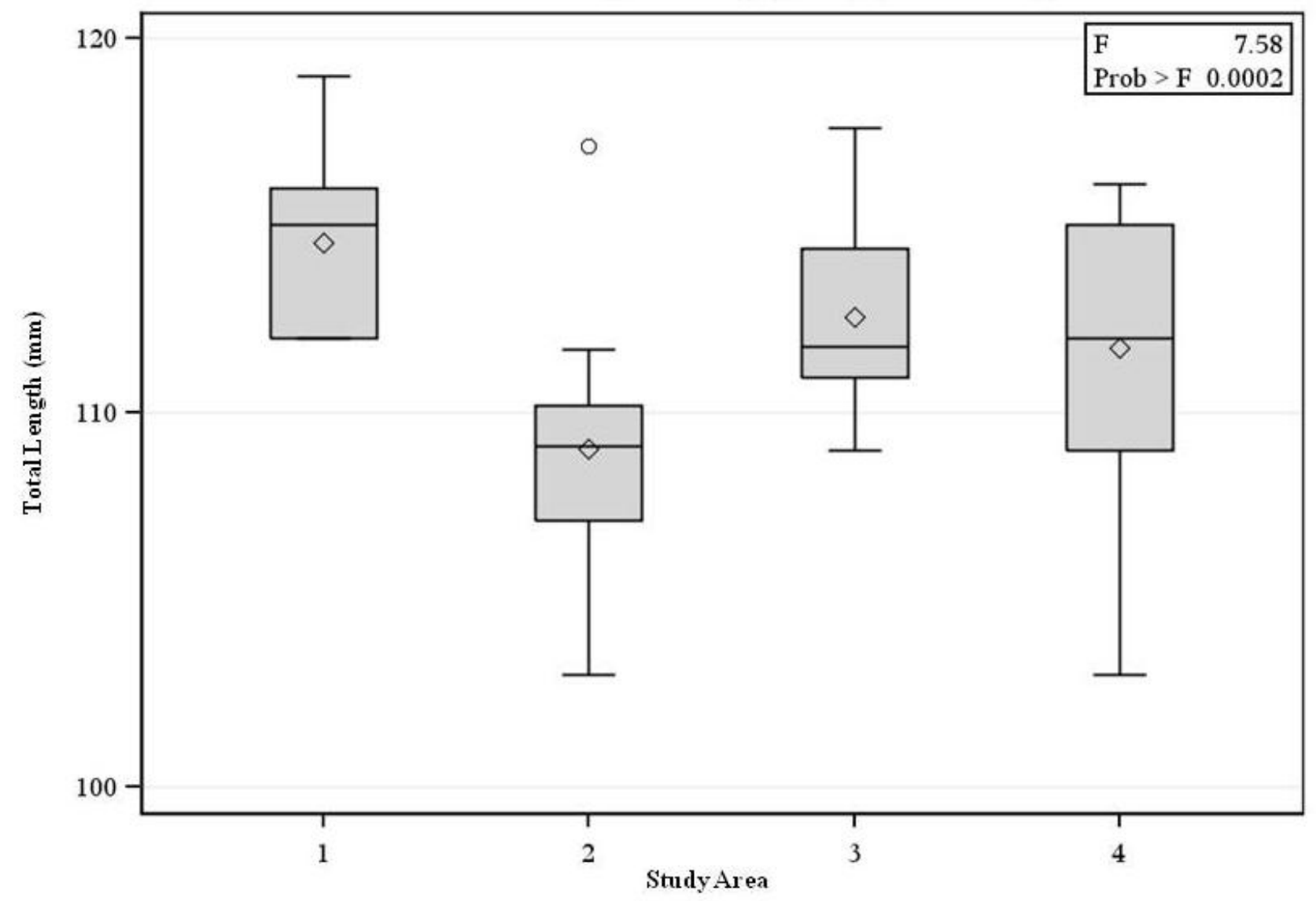

Fig. 22. Boxplot of total length (mm) of S. p. rhizophorae among study areas in Sonora, Mexico. 1= San Carlos $(n=11), 2=$ Bahia Kino $(n=14), 3=$ La Piedra $(n=16), 4=$ Yavaros $(n=23)$. 
Table 18. ANOVA post-hoc contrasts comparing weight measurements among study areas of $S$. p. rhizophorae. The mean weight of one study area was compared to the mean weight of all other study areas. 1= San Carlos, 2= Bahia Kino, 3= La Piedra, 4=Yavaros.

\begin{tabular}{lrrrrr}
\hline \multicolumn{1}{c}{ Contrast } & DF & \multicolumn{1}{c}{ Contrast SS } & Mean Square & F Value & \multicolumn{1}{c}{ Pr > F } \\
\hline 1 vs. $2,3,4$ & 1 & 0.24 & 0.24 & 0.51 & 0.48 \\
2 vs. $1,3,4$ & 1 & 0.01 & 0.01 & 0.01 & 0.91 \\
3 vs. $1,2,4$ & 1 & 2.07 & 2.07 & 4.43 & 0.04 \\
4 vs. $1,2,3$ & 1 & 4.59 & 4.59 & 9.84 & $<0.01$ \\
\hline
\end{tabular}


Distribution of Weight AmongS. p. rhizophorae Study Areas

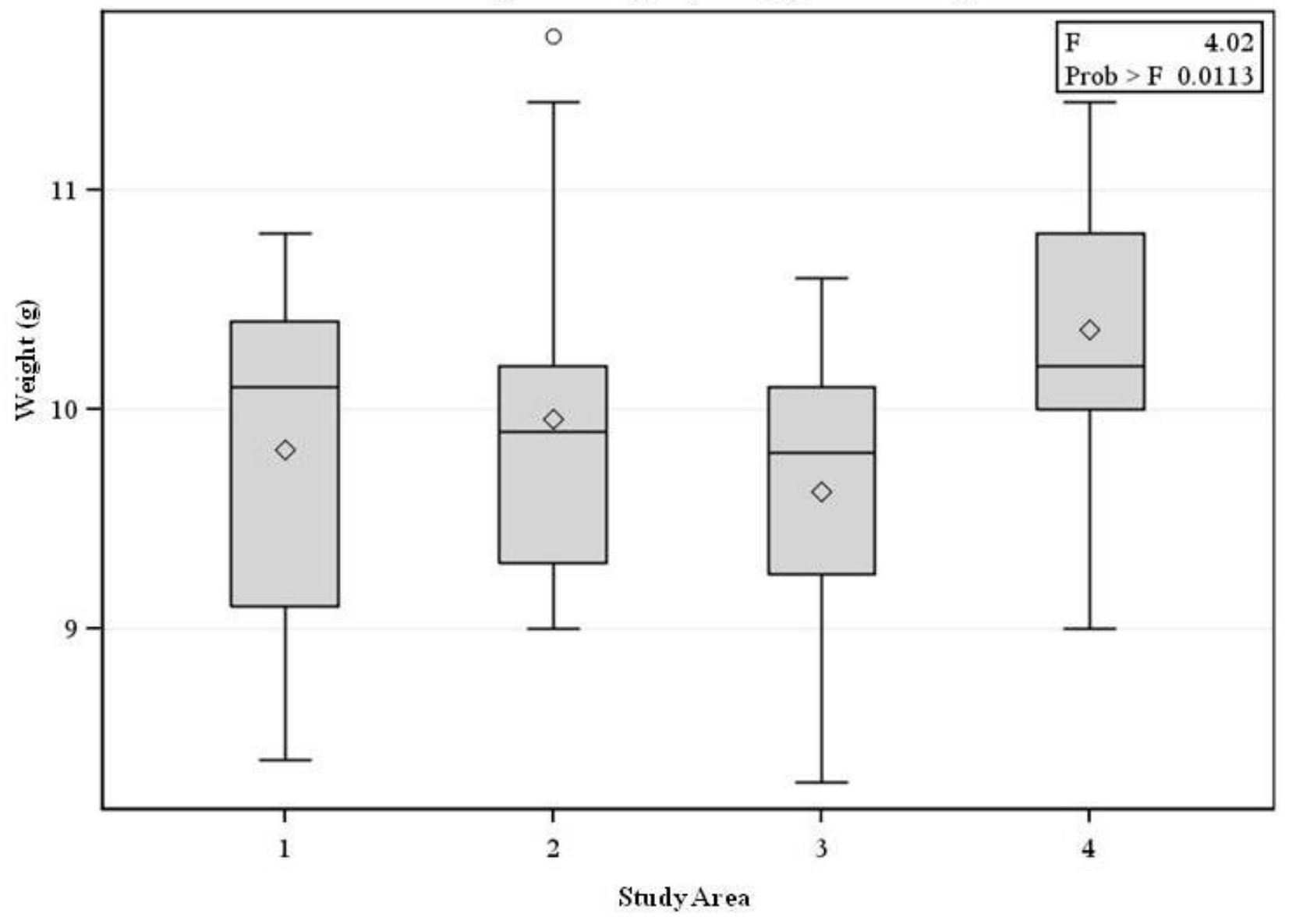

Fig. 23. Boxplot of weight (g) of $S$. p. rhizophorae among study areas in Sonora, Mexico. $1=$ San Carlos $(n=11), 2=$ Bahia Kino $(n=14), 3=$ La Piedra $(n=16), 4=$ Yavaros $(n=23)$. 


\section{CHAPTER III}

\section{YEAR ROUND MOVEMENTS OF A MANGROVE WARBLER SUBSPECIES SETOPHAGA PETECHIA CASTANEICEPS IN NORTHWESTERN MEXICO}




\section{INTRODUCTION}

The underlying framework for the conservation of fragmented populations is founded on the principles of island biogeography (MacArthur and Wilson 1967), wherein the probability of species occurrence in habitat patches varies as a function of patch size and isolation (Prugh et al. 2008). Simberloff (1974) stated, "Any patch of habitat isolated from similar habitat by different, relatively inhospitable terrain traversed only with difficulty by organisms of the habitat patch may be considered an island." Habitat islands are exposed to extinction through demographic stochasticity, environmental stochasticity, loss in genetic heterozygosity, edge effects, cultural erosion, and anthropogenic disturbance (Burkey 1995; Ludwig 1996). Rates of habitat fragmentation are so high that virtually all natural (continuous) terrestrial habitats and protected areas (such as nature preserves and parks) are certain to become habitat islands (Groombridge and Jenkins 2002).

The mangrove forest of Baja California Sur, Mexico is a mosaic of small islands as a result of habitat fragmentation due to increased pressures from human activities. Within twenty years (1972-92), 65\% of mangrove forests in Mexico were destroyed due to anthropogenic disturbance (Herrera-Silveira and Ceballos-Cambranis 2000), 70,000 ha lost between 1993 and 2000 (SEMARNAT 2003) (including 2,300 ha across Northwestern Mexico (early 1970's to 2005) (Ruiz-Luna et al. 2010)), and over 50\% of mangroves have been destroyed worldwide (Holguin et al. 2006). Furthermore, this region is affected by seasonal hurricanes which cause considerable damage on mangrove forests by reducing overall stem density and basal area and uprooting trees (Kovac et al. 2001). Not only are tropical depressions common, but $78 \%$ of the national total of hurricanes occur here (Flores-Verdugo et al. 1992). These influences combined with these weakened mangrove stands (e.g. those exhibiting homogeneous tree structure and 
diversity, gaps or breaks in continuous vegetation, and poor health from lack of microbial benthic communities) in this area, present a great concern to study these unique habitats and preserve their biodiversity.

Few birds specialize in mangrove forests, and detailed research of the ecology of confined mangrove birds is sparse (Hogarth 1999; Luther and Greenberg 2009). The Mangrove Warbler (Setophaga petechia castaneiceps) is an insectivorous passerine endemic to the mangroves of Baja California Sur. It is one of 43 recognized subspecies of the Yellow Warbler (Browning 1994), and believed to be a sedentary (although no published data have confirmed this), habitat specialist confined to the use of mangroves year round (Curson et al. 1994). Resident tropical birds occupy a relatively constant environment where periods of extreme cold and severe winter weather conditions are absent. Although these areas experience fluctuations in precipitation (i.e. dry and rainy seasons), the lack of extreme seasonality is a major driving force behind the ability of tropical birds to maintain year-long territories often with monogamous pair bonds (Cox 1968). As suitable mangrove habitat is declining, mangrove birds are forced into diminutive, isolated patches along the coastline leading to exposure to the dynamics of small, island populations.

Despite low human density in this area, there is increasing pressure on mangrove stands from anthropogenic activities (e.g. shrimp farming, rice cultivation, and urban development) which has led to localized destruction and fragmentation (Páez-Osuna et al. 2003; Brusca 2004; Glenn et al. 2006). Mangrove forests, and resultantly their inhabitants, may also be subject to more disturbance than other forests due to their exposure to typhoons, coastal erosion, and fluctuating river discharges (Hogarth 1999; Luther and Greenberg 2009). 
Considering the Mangrove Warbler specializes on a unique declining habitat, more research needs to be conducted to examine their movement patterns. Knowledge of their population movements will provide insight to immigration and emigration between mangrove stands, which is important for determining the susceptibility of the subspecies to consequences felt by isolated, small populations. Although the overall population size of S. p. castaneiceps is not known, it is reasonable to believe not many birds can be living in one patch due to the lack of available space and competition for resources such as nesting sites and food (e. g. Holmes 2010). Low individual numbers coupled with isolation and a sedentary lifestyle (possibly no immigration and emigration), may be resulting in low genetic variation (Harrison and Hastings 1996; Callens et al. 2011). There may be a high occurrence of inbreeding, thus leaving the populations more susceptible to environmental changes. Founder effects, or a bottle neck effect may have recently occurred due to hurricanes (e. g. five named hurricanes crossed Baja California Sur between 2001 and 2009; NOAA 2011) displacing individuals and destroying habitat, adding to genetic complications. Also, increased pressures from fragmentation may be felt by this subspecies due to the possible sensitivity to edge effect. Environmental stochasticity and catastrophes from living in coastal mangroves, in addition to the strengthened pressure of demographic stochasticity in their small populations may leave the viability of this subspecies uncertain and threatened with extinction.

\section{OBJECTIVE}

The main objective of this study was to quantify local movement of a presumed sedentary bird, S. p. castaneiceps. 


\section{HYPOTHESIS}

I hypothesize these birds are truly sedentary, moving only throughout localized mangrove stands. I believe the adult males are extremely territorial and defend their territory year round.

Ho: $S$. p. castaneiceps will show movement between mangrove stands throughout their breeding range.

Ha: $S$. p. castaneiceps will not move between mangrove stands throughout their breeding range.

I expect to find birds (adult males and females) inhabiting small patches in the Baja California Sur study sites, to be present year round in the mangrove stands in which they breed with no movement to surrounding mangrove stands that are separated by inhospitable habitat.

\section{STUDY AREA}

The study area included the known range of S. p. castaneiceps. S. p. castaneiceps inhabits patches of mangroves from both coasts of central Baja California Sur from San Ignacio and Pond lagoons south to about $27^{\circ} \mathrm{N}$ on the Gulf of California (Browning 1994; Dunn and Garrett 1994).

Baja California Sur has an annual precipitation $<300 \mathrm{~mm}$ and mean temperatures of 20$22^{\circ} \mathrm{C}$ classifying this as an arid climate (Ruiz-Luna et al. 2010). Mangroves in this study area are represented by three species, Avicennia germinans (black mangrove), Rhizophora mangle (red mangrove), and Laguncularia racemosa (white mangrove) (Hogarth 1999; Flores-Verdugo et al. 1992; Ruiz-Luna et al. 2010). Mangrove trees in Baja California Sur seldom exceed $5 \mathrm{~m}$ in height, unlike other tropical areas (Felger et al. 2001). Although there are no consistent patterns 
in species distribution or assemblage structure of mangroves in Mexico (Ruiz-Luna et al. 2010), study areas in Baja California Sur were dominated by red mangrove.

I placed 16 study sites in Baja California Sur based on locations reported in Whitmore et al. (2000) within 5 major study areas: La Paz, Magdalena Bay, Puerto Adolfo López Mateos (hereafter referred to as PALM), Mulegé and San Lucas (Fig. 1-6). Thirteen sites were situated on the Sea of Cortez coastline. Each study site was designated as a mangrove stand separated by inhospitable habitat from the next closest stand.

All study sites on the Sea of Cortez were less than $1.8 \mathrm{~km}$ (straight line distance) across at greatest distance (length or width) and were isolated patches separate from each other. All but one study site (LP6) on the Sea of Cortez coast were $<6$ ha in total area (Table 1). Magdalena Bay is a large continuous mangrove stand on the Pacific Coast of Baja California Sur. It stretches (straight line distance) approximately $115 \mathrm{~km}$ along the coast. The Magdalena Bay

study area had the greatest total area (67.8ha). The entire study area spanned a total straight line distance of $390 \mathrm{~km}$ and cumulative total area of 127.5ha. The overall average distance between neighboring study sites was $6.6 \mathrm{~km}$, but ranged from $0.91 \mathrm{~km}$ to $31.8 \mathrm{~km}$ (Table 1 ).

\section{Data Collection}

\section{METHODS AND MATERIALS}

I captured and banded Mangrove Warblers during the breeding season (March-July 2010) at each study site in Baja California Sur using mist nets and playback recordings of their songs as a decoy. General behavior was recorded for all observed individuals during the playback to determine territoriality. A male, female, or pair was considered to be actively defending a territory when exhibiting wing flutters, flying at the speaker or observer, chipping, chasing other 
birds, or counter-singing to playback. Within any study site, multiple locations (i.e. net lanes) were used to conduct necessary field work. As many individuals as possible were captured to maximize sample size.

Each bird was banded with a U.S. Geological Service aluminum band and unique color combination (4 color plastic bands) for individual identification (Permit \# 20580). The leg containing the federal band was marked with a color band corresponding to one of the five major study areas (La Paz, Magdalena Bay, PALM, Mulegé, and San Lucas). The other leg was marked with three color bands. At the time of capture, all locations were recorded via GPS unit with a minimum of $10 \mathrm{~m}$ accuracy. After processing, birds were released at point of capture.

Age was determined through plumage and skull pneumatization (Howell and Webb 1995; Pyle 1997). Birds were categorized into hatch year (HY) and after hatch year (AHY) year classes. Sex, male (M) or female (F), was determined through coloration and presence of brood patch/cloacal protuberance (Howell and Webb 1995; Pyle 1997). All individuals that were not capable of being sexed were classified as unknown (U). Skull pneumatization was based on a 06 scale, where 0 indicates no ossification and 6 indicates full ossification of the skull. A class 6 skull indicates an AHY individual. A pair was recorded if both a female and male were captured at the same location and defended the territory together.

As reported by Salgado- Ortiz et al. (2008), D. p. bryanti in Celestun, Mexico defended territories and maintained permanent pair bonds and stable population density year round. Since I was interested in year round movements within the S. p. castaneiceps population(s), banded adult males and females were re-trapped and/or re-sighted throughout differing periods of the year (Morton and Stuchbury 2000). Adult Mangrove Warblers in Baja California Sur were resighted/re-trapped in late fall/early winter (November 2010) and breeding season (April 2011). 
The November 2010 re-sighting period is the wintering re-sighting period and April 2011 is referred to as the breeding re-sighting period. This re-sight schedule allowed for a year round observation of a presumed sedentary bird.

Re-sighting and re-trapping both took place at points of original capture (net locations). Each point of original capture was visited at least once within the differing periods as described above. At each location, I broadcasted conspecific vocalizations to call individuals to the area. Broadcasts were played for 15 minutes or until an individual (banded or unbanded) was seen or heard. All detected (observed and heard) individuals of all ages and sexes were recorded during the 15 minute time period within a $10 \mathrm{~m}$ radius surrounding the point (Hutto et al. 1986). General behavioral notes also were collected during re-sighting attempts. I chose a small radius due to the density of the vegetation and to ensure $100 \%$ detection. More time was spent at the re-sighting location if band confirmation was needed, however no individuals were recorded after the 15 minute survey.

If re-trapping was used, all individuals were target netted with mist nets after the 15 minute re-sighting period. I re-trapped mangrove warblers if they were un-banded, to assess the condition of their bands, replace missing color bands, or needed to confirm band combination (of previously banded individuals). I found the color bands faded throughout the year due to high exposure to sun and salt. Captured unmarked individuals were banded, measured, and released.

To standardize re-sighting efforts, net hours and observation hours were recorded to keep effort as equal as possible (Winker et al. 1997) per original capture location. They also occurred during the same time periods of the day of original capture and under desirable field conditions, with slight differences due to yearly changes in sunrise/sunset times. By standardizing re-sight efforts by original capture location (regardless of how many birds were captured at that location) 
I attempted to keep the distance the broadcasts could be heard equal, thus reducing the amount of birds that may have been drawn in to the area of broadcast.

I followed methods for recording re-sights of banded bird data in SWCA Environmental Consultant's Southwestern Willow Flycatcher Re-sight Protocol (SWCA unpubl.). Observations (via 10X42 binoculars) were recorded noting the order and color of the bands on the respective legs, the location of the bird (via GPS waypoint), and confidence level for the observation. Resighting was recorded on an A, B, or C classification level. An 'A' confidence level consisted of an observation recorded at $100 \%$ confidence of the full band combination of both legs and it must be observed twice. A 'B' re-sight entailed a $100 \%$ confidence level of the full band combination on both legs, but it was only observed once. Any other observations of full band combinations or partial band combinations on only one or both legs were classified as a ' $\mathrm{C}$ ' resight. To eliminate observer bias, no discussion of band combos was shared amongst observers.

\section{Data Analyses}

Only males and females captured during the 2010 breeding season were referred to as the banded population. Unless noted, I assumed all points of original capture during the 2010 breeding season were the active territories of the responding individuals due to territorial behavior. All individuals that could not be reliably sexed were excluded from analyses. Individuals that were detected multiple times during a re-sighting survey point were only counted once. If an individual followed the observers to a neighboring re-sighting point (which was obvious in the field), it was only counted once at the point where it actively defended a territory. 
Re-sighting success was defined as the percent of re-sighted individuals from the total banded population during each re-sighting period. This was calculated by dividing the total number of re-sighted individuals by the total banded population and multiplying this number by 100 to achieve a percentage. Due to some study sites being visited more often than others throughout the breeding and non-breeding re-sighting periods, percent re-sighted individuals by effort was needed. Percent re-sighted individuals by effort were calculated by dividing total resighted individuals by total attempted re-sighted individuals. The total number of attempted resighted individuals was calculated by subtracting the total amount of birds with no re-sight effort from the total banded population. This number was then multiplied by 100 to obtain a percentage. Population density was calculated by dividing the number of individuals detected during the 15 minute surveys by respective area (ha) of study area, study site, and overall.

A repeated measures analysis of variance (ANOVA) was used to test for any significant differences among breeding (2010 and 2011) and wintering (2010) bird densities for all sex categories (male, female, and pair). This test was run using statistical software SAS (version 9.2). We checked the normality of the response variable density through graphical exploration (histograms and quantile-quantile plots) and Shapiro-Wilk normality tests. We learned the data were skewed to the right and required transformation to reduce the spread of the response variable and lead to a better approximation of normality to satisfy ANOVA test assumptions. We found the cube root transformation was the best transformation to the data to approximate normality.

The cube root transformed data were then used in SAS (version 9.2) in a mixed model repeated measures analysis of variance exploring three different covariance structures: Unstructured, Autoregressive (AR1), and Toeplitz. We selected the covariance structure that 
best fit the data by means of several different criteria including Akaike Information Criterion (AIC), AIC corrected (AICc) and the Bayesian Information Criterion (BIC). We used the same predictor variables for these models, but the covariance structure between the repeated measures was best explained by the AR1 covariance structure in comparison to the other alternative covariance structures. A result was significant when $\mathrm{p}<0.05$.

The re-sight data were then used to determine individual movements throughout the year. I used ESRI ArcMap 9.3.1 to assess distances moved by banded individuals from their original capture location. I determined territory switching and territory replacement in individuals by confirming waypoints with re-sighting data and comparing this to previous confirmed locations of the individual. I calculated the closest straight line distance of movements using ESRI ArcMap 9.3.1 measure tool.

\section{RESULTS}

\section{Capture, Territoriality, and Re-sighting Success}

I captured and banded 74 adult males and 34 adult females (28 pairs; Fig. 7) during the 2010 breeding season at 57 capture locations within the 16 study sites. Every individual captured was actively defending its territory. Chipping was the main territorial cue used by Mangrove Warblers both in the wintering season and breeding season. Song was only secondary in defending their territory. Although minimal song was used in the morning (morning chorus) of the breeding season, it was infrequent and chip notes between birds were used more reliably to communicate. Playing song and chip notes during both re-sighting periods led to aggression in both the male and female territory holders in which they would chase off any (including migrant yellow warblers) intruding individuals. Adult male movement involved more flying and chasing 
whereas female aggression was harsh chipping companied by hopping internally throughout the mangrove trees looking for the unrecognized individual.

I re-sighted 43 marked males and 13 marked females, obtaining a total re-sight success of $51.9 \%$ of the total banded population. Nine marked males and 2 marked females were resighted both in the spring and winter re-sighting periods. I re-sighted 4 retained pair bonds throughout the course of this study. The highest number of re-sighted marked birds $(n=25)$ was in the La Paz study area, whereas the lowest (n=6) was in Magdalena Bay (Fig. 7). Mulegé study area had the greatest percent of re-sighted banded males (75.0\%) and the greatest percent of re-sighted banded females (55.6\% 0) (Table 2). Marked males had an overall re-sight success of $58.1 \%$ whereas females were $38.2 \%$ (Table 2). A higher percentage of males and females $(37.3 \%(\mathrm{n}=22)$ and $20.0 \%(\mathrm{n}=5)$ respectively) were re-sighted during the winter period compared to the spring re-sighting period (29.7\% and $14.29 \%$ respectively, Table 2$)$.

\section{Population Density}

Density of adult males, adult females and pairs was highest in the San Lucas study area in the 2010 breeding season (2.2/ha, 1.7/ha, and 1.7/ha respectively) and 2010 wintering season (1.5/ha, 1.0/ha, and 1.0/ha respectively) (Table 3). The Mulegé study area had the highest density of males, females and pairs (1.1/ha) in the 2011 breeding season (Table 3). The overall average year-round adult male density was $1.3 /$ ha, adult year-round female density $0.9 /$ ha, and adult year-round pair density $0.9 /$ ha. Males had a significantly higher density across all seasons (Breeding 2010, Wintering 2010, Breeding 2011) $(\mathrm{F}=4.27, \mathrm{dF}=132, \mathrm{P}=0.02)$ (Table 4) compared to females and pairs (Fig. 8). There was no significant change in overall Mangrove Warbler density across seasons (Table 4, Fig. 9). 


\section{Territory Switching}

By comparing location of original capture versus location of re-sight, I detected no among patch movements throughout the $S$. p. castaneiceps population. Some banded adults, however, moved their territories to different locations (territory switching) within their study site between the breeding periods (2010-2011). All movements were recorded to occur between the wintering (2010) and breeding (2011) re-sighting periods. Movement of a territorial banded male to another territory was witnessed 8 times with an average distance of $0.59 \mathrm{~km}$ between locations (Table 5). Females were only found to move to a new territory once, which was to the closest neighboring territory with a male.

\section{Territory Replacement}

A territory became vacant 68 times during the study (Table 6). An open territory was filled by another male, hereafter called territory replacement, $68.1 \%(n=32$ replacements of 47 vacancies) of the time. An opening in a female position was filled $66.7 \%(n=14$ replacements of 21 vacancies) of the time it occurred. Unbanded males and females were more likely to fill vacant territories $(n=25)$ than banded males and females $(n=7, n=1$, Table 6). Most re-sighted individuals from a pair bond were replaced in the absence of one individual $(n=11)$. All but four of the territory replacements were noted during the breeding season (2011) re-sighting period, compared to the wintering (2010) re-sighting period

\section{DISCUSSION}

My results confirm the Mangrove Warbler, S. p. castaneiceps, is a resident tropical passerine of Baja California Sur, Mexico. The Mangrove Warbler has minimal seasonal 
movements (both adult male and female) and was observed to actively defend its territory year round (pers. obs.), much like other tropical passerines (Greenberg and Gradwohl 1986, 1997; Lefebvre et al. 1992; Morton et al. 2000; Salgado-Ortiz et al. 2008). Although not all banded individuals were re-sighted and new unbanded adult mangrove warblers were witnessed in various mangrove sites during both re-sighting periods, it is plausible to believe $S . p$. castaneiceps is a sedentary species performing only post-juvenile movements. Lack of resighting success could be due to mortality, loss of bands, or missed detection. Lack of resighting success cannot be due to emigration of individuals from study sites because all mangrove stands in Baja California Sur were surveyed. The unbanded adults may have been present but missed during original (2010 breeding) surveys due to lack of territorial behavior. Mangrove stands are densely vegetated (Hernández et al. 2011) making it difficult to see Mangrove Warblers. Furthermore, no movement from original mangrove sites were recorded in any re-sighted individual.

Despite high replacement of individuals in these patches, territory occupancy and density of $S$. p. castaneiceps remained moderately stable throughout the year, much like $D . p$. brayanti (Salgado-Ortiz et al. 2008). This pattern is consistent with other tropical, sedentary birds (Cox 1985; Greenberg and Gradwohl 1986, 1997; Gorrell et al. 2005). I documented only one addition of a territorial pair to a mangrove patch. A higher year round density of males compared to females and pairs may be due to a higher detection rate due to heightened territorial defense. 


\section{Territory Switching}

Movement of a territorial banded male to another territory was witnessed 8 times $(18.6 \%$ of re-sighted males). Of these territory movements, all males were seen with a new female. One male was documented to switch his territory to a neighboring territory (abandoning his pair bond), pair with the existing female in that territory, and recruit an additional female which was from another neighboring pair with an absent male. Age is irrelevant in these movements because all individuals were aged as ASY during the re-sighting periods.

Territory switching in year-round territorial tropical birds is both common (e.g. occurred in $37.5 \%$ of known aged Checker-throated Antwrens; Greenberg and Gradwohl 1997) and very responsive to territory vacancies (<1 day) (Levin 1996; Morton et al. 2000). Mangrove Warblers use the most common type of territory such that courtship, mating and nest-building all occurred within the territory boundary, and the young and adults were fed food from within this territory (Welty and Baptista 1988). Territory switching may be due to access to a territory of higher resources or to a mate (Morton et al. 2000; Fedy and Stutchbury 2004). Whether the original territorial males were displaced or died, and resultantly replaced by another individual is unknown.

Removal trials in a sedentary tropical bird (White-bellied Antbird, Myremeciza longipes) have shown when adult males were temporarily removed from their territories, some neighboring territorial males switched to the new open territories (Fedy and Stuchbury 2004). Territory switching to increase food availability (Gorrell et al. 2005) and foraging substrate (Morton et al. 2000) has also been recorded in other species of resident territorial birds. This may help to increase adult survivorship and fitness of an individual. 


\section{Territory Replacement}

I observed high individual replacement throughout the study (53.19\% males, $61.90 \%$ females). In habitats with stable population density and year-long territorial birds, it is common that vacant territories are filled within a matter of hours (Greenberg and Gradwohl 1997; Morton et al. 2000; Fedy and Stutchbury 2004). In the wintering re-sighting period, I observed many birds throughout the mangrove sites but it is unconfirmed whether these were migrant Yellow Warblers (aestiva group), juvenile Mangrove Warblers, or floaters. It is unknown where or when these individuals moved to the vacant territories, but it is plausible to believe these individuals were floaters. Probable explanations of high occurrence of floaters in these mangrove stands could be due to lack of natal dispersion and emigration, suitable habitat is limited for territory establishment, or possibly as a response to an increase in male population density (Smith et al. 2006), however this would refute the findings that floaters are uncommon in these type of territorial systems (Levin 1996; Morton et al. 2000; Fedy and Stuchbury 2004).

It is possible that the individuals that gained access to the territories were the young from the previous year (as a function of density dependence) (Woolfeden and Fitzpatrick 1984). It is unknown whether the young disperse among mangrove stands, as no juvenile Mangrove Warblers were captured and banded during this study. Salgado Ortiz et al. (2008) found Mangrove Warbler (D. p. bryanti) fledglings to remain on natal territories for an average of 27.4 days, however there is no information regarding their movements/dispersal after this time.

Smith et al. (2006) reported 35\% territory replacement by first year floaters for a resident island population of Song Sparrows (Melospiza melodia). They also reported about 25\% of the displaced territory holders became floaters on their previously held territory. Age was found to be important in these territory replacements whereas males 2 and 3 years old (which are both 
considered adults) were more likely to take over territories compared to juvenile males and adults 4 years and older. 


\section{LITERATURE CITED}

Browning, M. R. 1994. A taxonomic review of Dendroica petechia. Proceedings of Biological Sciences Washington 107:27-51.

BRUSCA, R. C. 2004. The Gulf of California-an overview. in Seashore Guide to the Northern Gulf of California. Arizona-Sonora Desert Museum, Tucson, AZ.

BURKEY, T. V. 1995. Extinction rates in Archipelagoes: Implications for populations in fragmented habitats. Conservation Biology 9:527-541.

Callens, T., P. Galbusera, E. Matthysen, E. Y. Durand, M. Githiru, J. R. Huyghe, and L. LENS. 2011. Genetic signature of a population fragmentation varies with mobility in seven bird species of a fragmented Kenyan cloud forest. Molecular Ecology 20:18291844.

Cox, G. W. 1968. The role of competition in the evolution of migration. Evolution 22:180-192.

Cox, G. W. 1985. The evolution of avian migration systems between temperate and tropical regions of the New World. American Naturalist 126:451-474.

Curson, J., D. Quinn, AND D. BEAdle. 1994. New World Warblers. A \& C Black, London.

Dunn, J. L., AND K. L. GarretT. 1997. A Field Guide to Warblers of North America. Houghton Mifflin, Boston.

FEDy, B. C. AND B. J. M. StutchBury. 2004. Territory switching and floating in White-bellied Antbird (Myrmeciza longipes) a resident tropical passerine in Panama. Auk 121:486-496.

Felger, R. S., M. B. Johnson, And M. F. WiLson. 2001. The trees of Sonora, Mexico. Oxford University Press, New York.

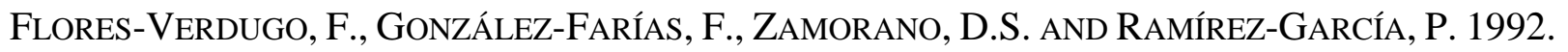
Mangrove ecosystems of the Pacific coast of Mexico: distribution, structure, litterfall, and detritus dynamics. Pages 269-288 in Coastal Plant Communities of Latin America (U. Seeliger, Ed.). Academic Press, California.

Glenn, E. P., P. L. Nagler, R. C. Brusca, And O. HinojosA-Huerta. 2006. Coastal wetlands of the northern Gulf of California: inventory and conservation status. Aquatic Conservation 16:5-28.

Gorell, J. V., G. Ritchison, And E. S. Morton. 2005. Territory size and stability in a sedentary neotropical passerine: is resource partitioning a necessary contition? Journal of Field Ornithology 76:395-401. 
GREENBERG, R., AND J.GradWOHL. 1986. Constant density and stable territoriality in some tropical insectivorous birds. Oecologia 69:618-625

GREENBERG, R. AND J. GRADWOHL. 1997. Territoriality, adult survival, and dispersal in the Checker-throated Antwren in Panama. Journal of Avian Biology 28:103-110.

GROOMBRIDGE, B. AND M. JENKINS. 2002. World atlas of biodiversity: earth's living resources in the $21^{\text {st }}$ century. University of California Press, Berkeley.

HARrison, S. AND A. HASTINGS. 1996. Genetic and evolutionary consequesnces of metapopulation structure. Trends in Ecology and Evolution 11:180-183.

Hernández, C. M. A., C. G. S. Zaragoza, S. Iriarte-Vivar, F. J. Flores-Verdugo, And P. M. CASASOLA. 2011. Forest structure, productivity and species phenology of mangroves in the La Mancha lagoon in the Atlantic coast of Mexico. Wetlands Ecology and Management 19:273-293.

Herrera-Silveira, J., AND E. Ceballos-CAmbranis. 2000. Manglares: ecosistemas valiosos. Biodiversitas 19:1-10.

Hogarth, P. J. 1999. The Biology of Mangroves. Oxford University Press, New York.

Holguin, G., P. Gonzalez-Zamorano, L. E. de-Bashan, R. Mendoza, E. Amador, And Y. BASHAN. 2006. Mangrove health in an arid environment encroached by urban development- a case study. Science of the Total Environment 63:260-274.

Holmes, R. T. 2010. Avian population and community processes in forest ecosystems: long-term research in the Hubbard Brook experimental forest. Forest Ecology and Management 262:20-32.

Howell, S. N. G., AND S. WebB. 1995. A Guide to the Birds of Mexico and Northern Central America. Oxford University Press, New York.

Hutto, R. L., S. M. Pletschet, AND P. Hendricks. 1986. A fixed-radius point count method for nonbreeding and breeding season use. Auk 103: 593-602.

Kovac, J. M., M. Blanco-Correa, And F. Flores-Verdugo. 2001. A logistical regression model of hurricane impacts in a mangrove forest of the Mexican Pacific. Journal of Coastal Research 17:30-37.

Lefebvre, G., B. Poulin, AND R. MCNeIL. 1992. Settlement period and function of long-term territory in tropical mangrove passerines. The Condor 94:83-92.

LEVIN, R. N. 1996. Song behavior and reproductive strategies in a duetting wren, Thryothorus nigricapillus: I. Revoval experiments. Animal Behaviour 52:1093-1106. 
LUDWIG, D. 1996. The distribution of population survival times. The American Naturalist 147:506-526.

Luther, D. A., AND R. GREENBERG. 2009. Mangroves: A global perspective on the evolution and conservation of their terrestrial vertebrates. BioScience 59:602-612.

MacARthuR R. H. AND E. O. WiLson. 1967. The theory of island biogeography. Princeton University Press, New Jersey.

Morton, E. S., AND B. J. M. StutchbuRy. 2000. Demography and reproductive success in the dusky antbird, a sedentary tropical passerine. Journal of Field Ornithology 71:493-500.

Morton, E. S., K. C. Derrickson, AND B. J. M. Stutchbury. 2000. Territory switching behavior in a sedentary tropical passerine, the dusky antbird (Cercomarcra tyrannina). Behavorial Ecology 11:648-653.

NAtional OcEanic And Atomopheric Administration (NOAA). 2011. Center for Coastal Studies. Historical hurricane tracks: Estado de Baja California Sur, state, Mexico. [Online.] Available at www.csc.noaa.gov/hurricanes/\#app=3d30\&3e3d-selectedIndex $=0$.

Páez-Osuna, O., A. Gracia, F. Flores-Verdugo, L. P. Lyle-Fritch, R. Alonso-Rodríguez, A. ROQUE, AND A. C. RUIZ-FERNÁNDEZ. 2003. Shrimp aquaculture development and the environment in the Gulf of California ecoregion. Marine Pollution Bulletin 46:806-815.

Prugh, L., K. E. Hodges, A. R. E Sinclair, AND J. S. Brashares. 2008. Effect of habitat area and isolation on fragmented animal populations. Proceedings of the National Academy of Sciences 105:20770-20775.

PyLE, P. 1997. Identification Guide to North American Birds, Part I. Slate Creek Press, California.

Ruiz-Luna, A., A. Cervantes Escobar, and C. Berlanga-Robles. 2010. Assessing distribution patterns, extent, and current condition of Northwest Mexico mangroves. Wetlands 30:717-723.

Salgado-Ortiz, J., P. P. MarRa, T. S. Sillett, AND R. J. Robertson. 2008. Breeding ecology of the mangrove warbler (Dendroica petechia bryanti) and comparative life history of the yellow warbler subspecies complex. Auk 125:402-410. 
SECRETARia de Medio Ambiente y ReCursos NATURALES. NORMA Oficial MeXiCANA NOM-022-SEMARNAT-2003, QUE ESTABLECE LAS ESPECIFICACIONES PARA LA PRESERVACIÓN, CONSERVACIÓN, APROVECHAMIENTO SUSTENTABLE Y RESTAURACIÓN DE LOS HUMEDALES COSTEROS EN ZONAS DE MANGLAR [Ministry of environment and natural resources. Mexican official standard NOM-022-SEMARNAT-2003, establishing the specifications for the preservation, conservation, development and restoration of coastal wetlands in mangrove areas], Diario Official de la Federación, [D.O.], 10 Abril de 2003 (Mex.).

SIMBERLOFF, D. 1974. Equilibrium theory of island biogeography and ecology. Annual Review of Ecology and Systemaitcs 5:161-188.

SMith, J. N. M, L. F. Keller, A. B. MARr, AND P. ARCESE. 2006. Conservation and biology of small populations: the Song Sparrow of Mandarte. Oxford University Press, New York.

WELty, J. C. AND L. BAPTISTA. 1988. The life of birds. $4^{\text {th }}$ ed. CBS College Publishing, New York.

Whitmore, R. C., R. Craig Whitmore, And M. W. Whitmore. 2000. Distributional notes on the Mangrove Warbler (Dendroica petechia castaneiceps) near the northern edge of its range in Eastern Baja California Sur, Mexico. Western North American Naturalist 60:228-229.

Winker, K., P. Escalante, J. H. Rappole, M. A. Ramos, R. J. Oehlenschlager, And D. W. WARNER. 1997. Periodic migration and lowland forest refugias in a "sedentary" neotropical bird, Wetmore's Bush-Tanager. Conservation Biology 11:692-697.

WoOlfenden, G. E. AND J. W. FitZPATRICK. 1984. The Florida scrub jay: demography of a cooperative-breeding bird. Princeton University Press, New Jersey. 


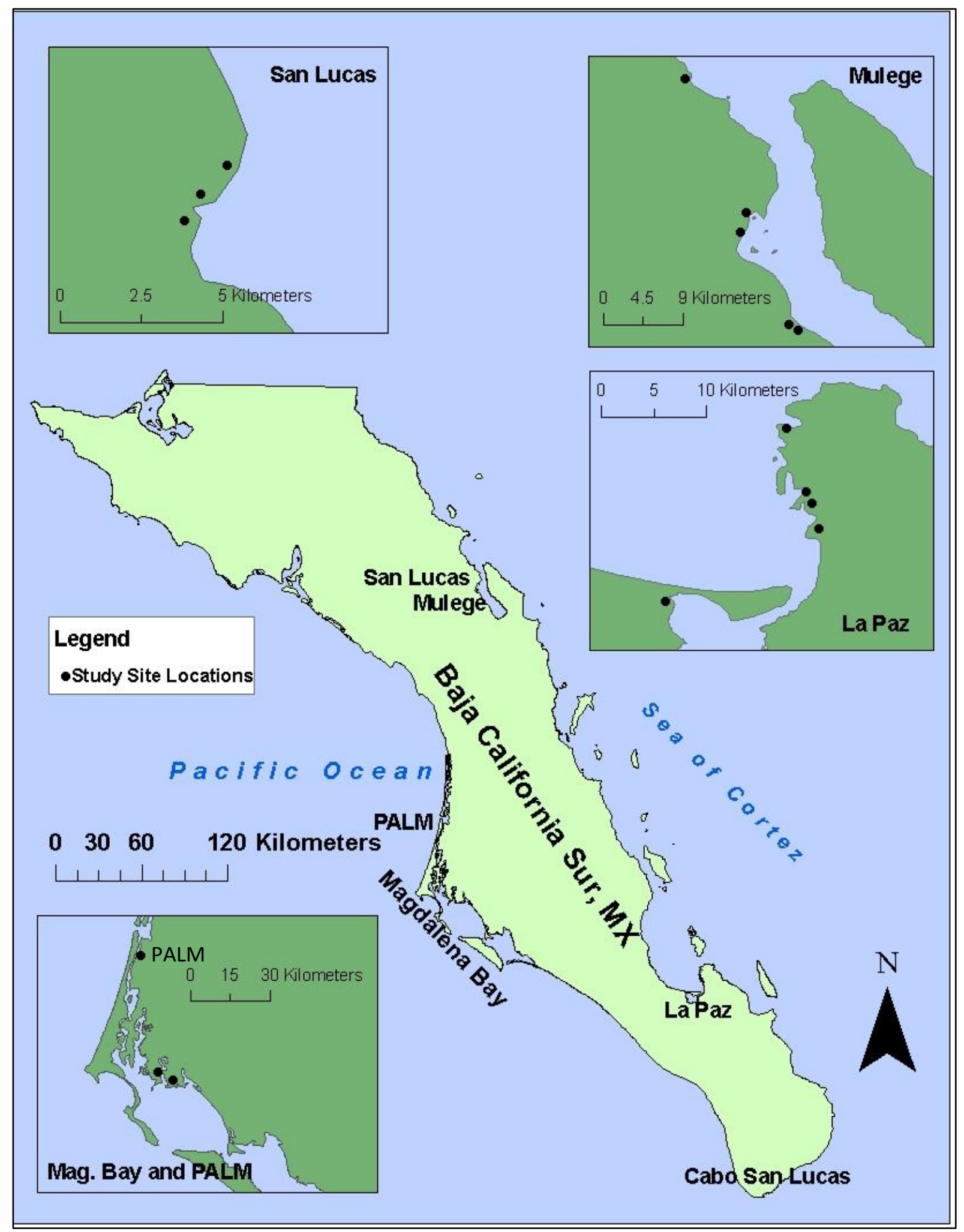

Fig. 1. Five major study areas (San Lucas, Mulegé, Puerto Adolfo López Mateos (PALM), Magdalena Bay, and La Paz) and study site locations in Baja California Sur, Mexico. 

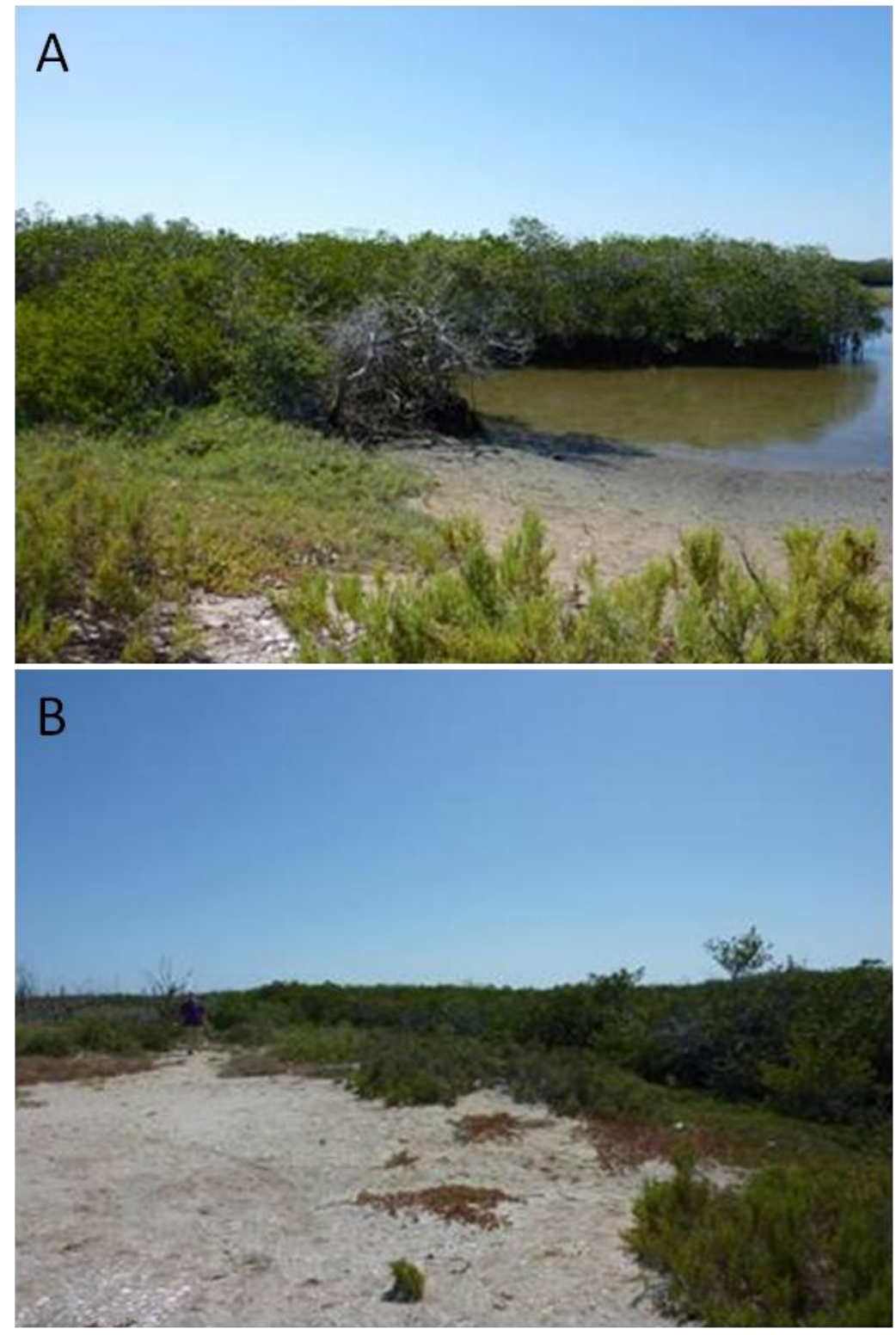

Fig. 2. Magdalena Bay study area, Baja California Sur, Mexico, from lagoon (A) and interior (B). 


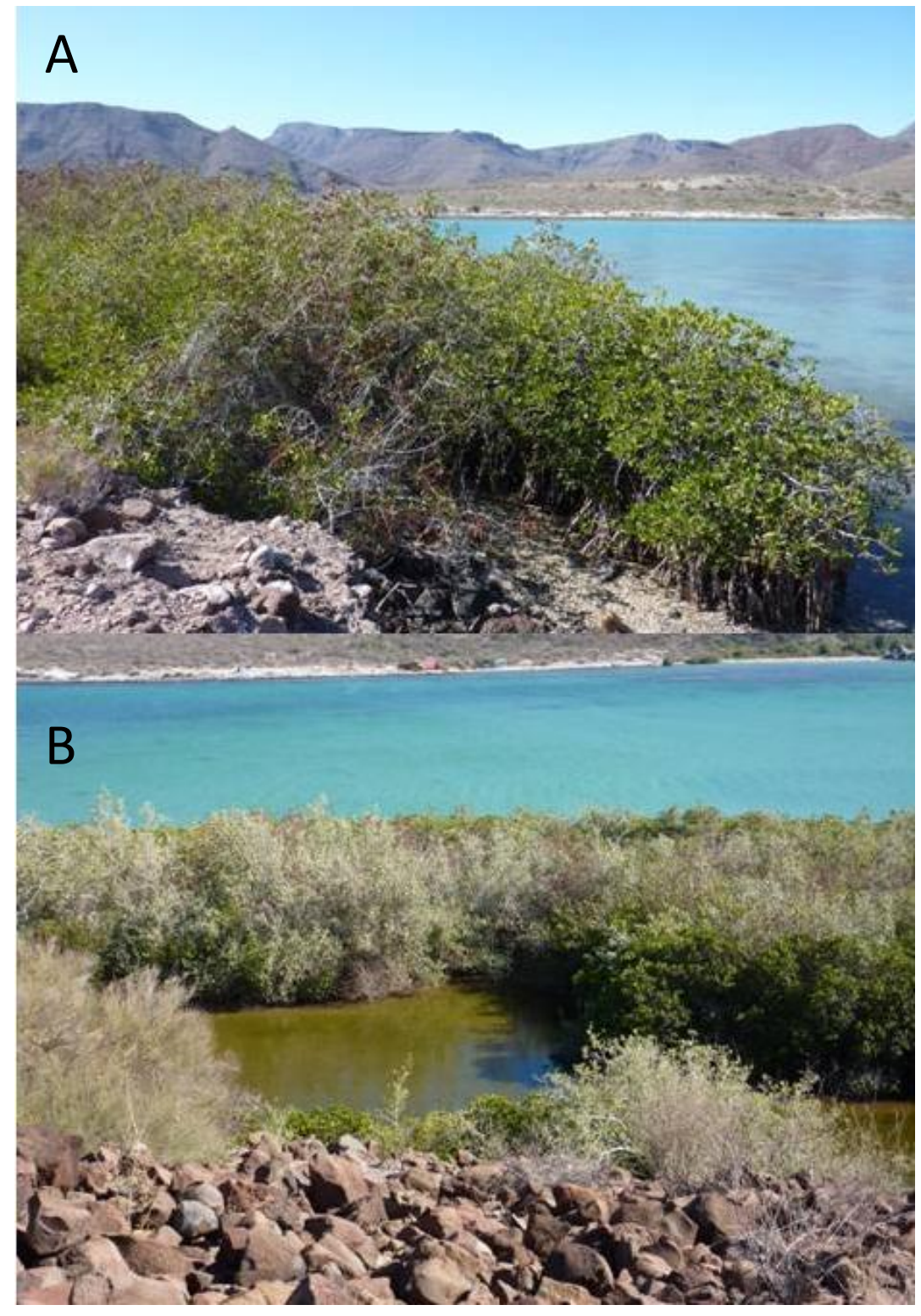

Fig. 3. Mulegé study area, Baja California Sur, Mexico from coast (A) and showing common brackish lagoons within mangrove stands (B). 


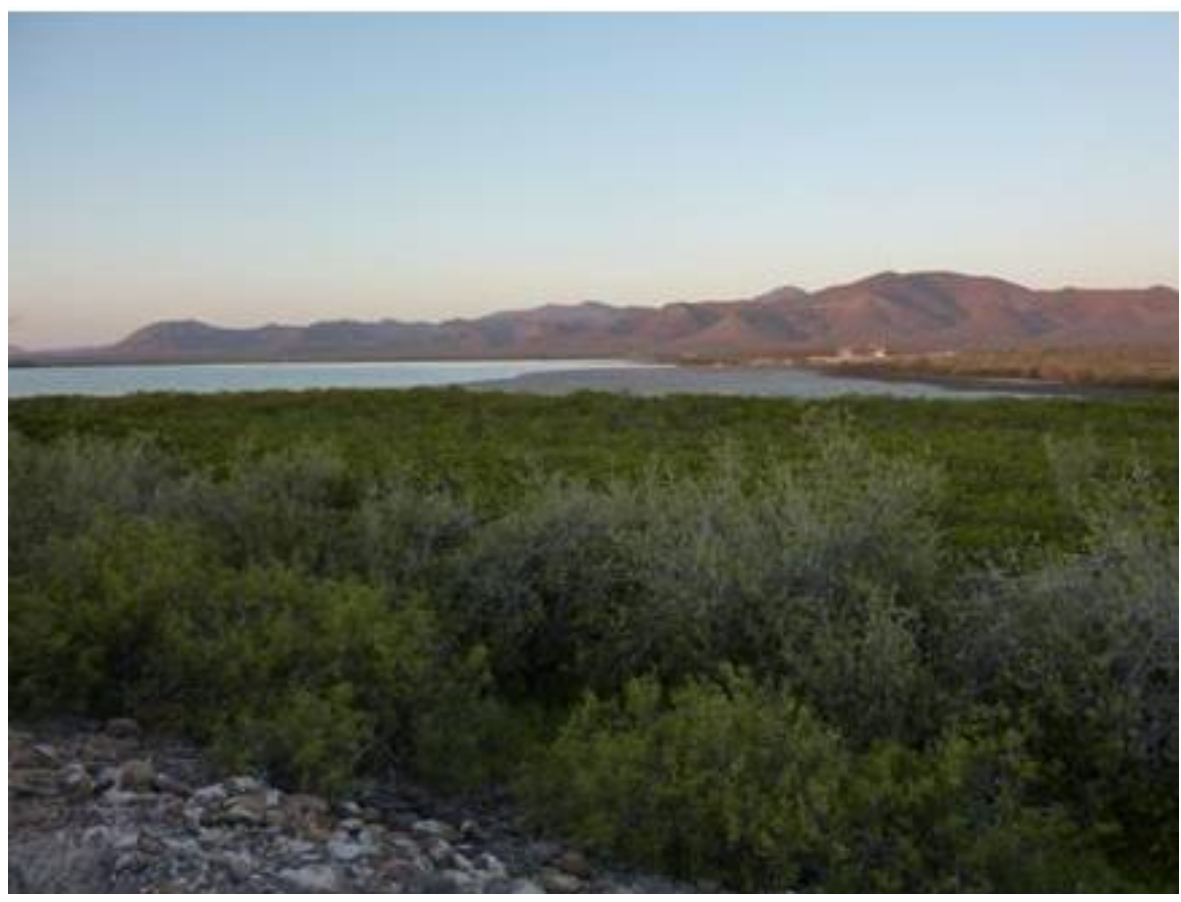

Fig. 4. San Lucas study area, Baja California Sur, Mexico. 

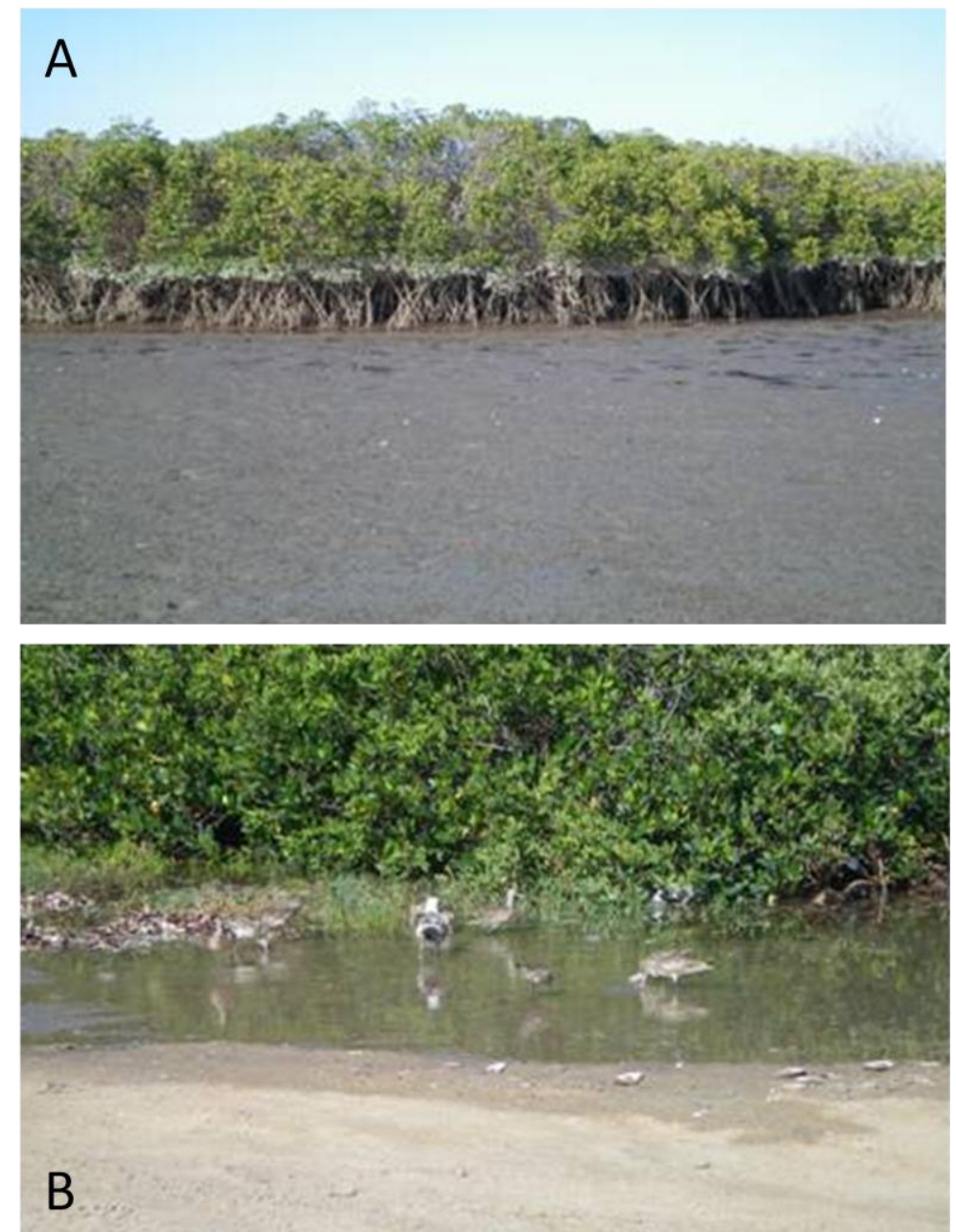

Fig. 5. Puerto Adolfo López Mateos (PALM) study area, Baja California Sur, Mexico from coast at low tide (A) and interior (B). 

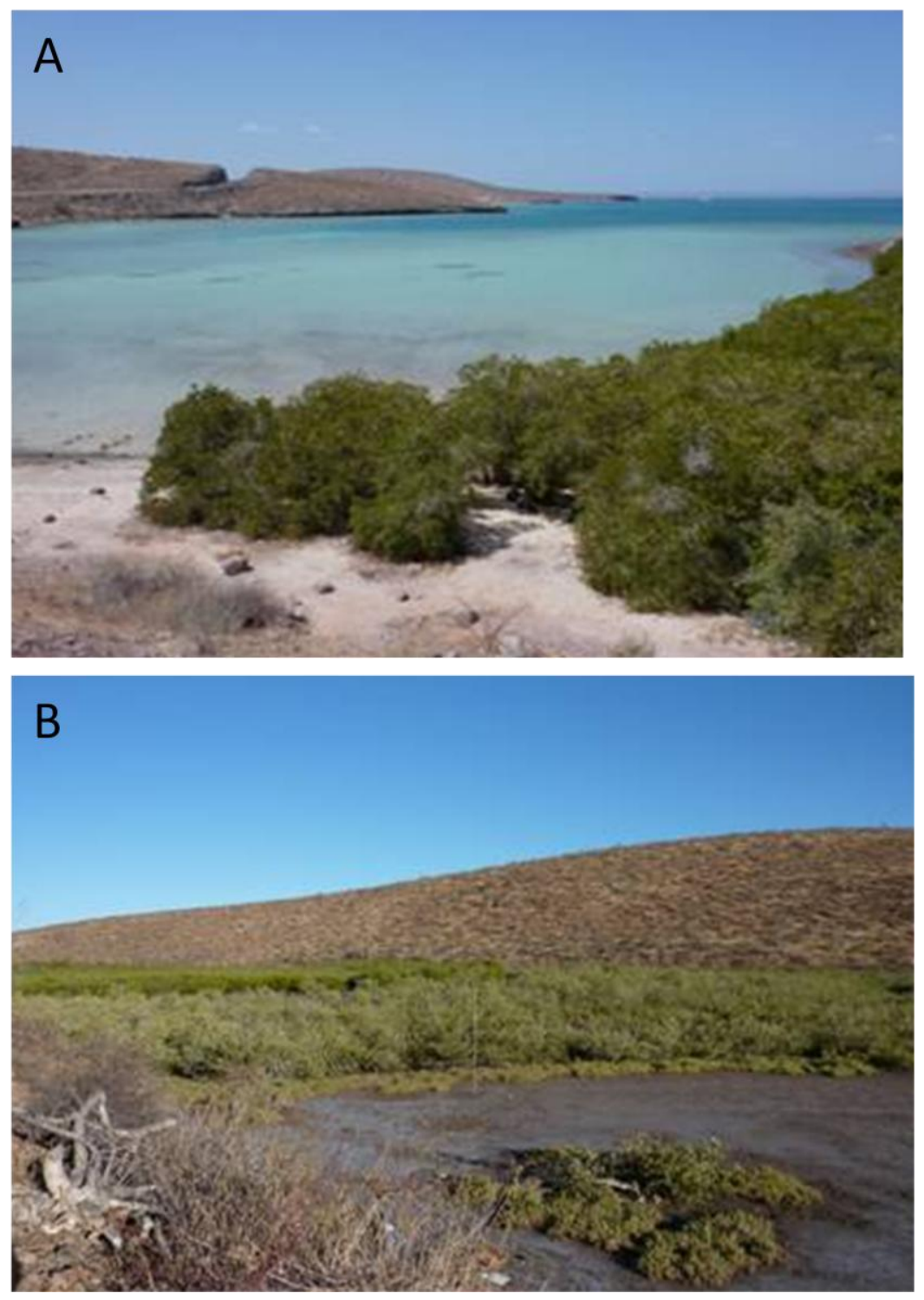

Fig. 6. La Paz study area. Baja California Sur, Mexico from coast (A) and interior (B). 
Table 1. Area and perimeter of study areas and study sites in Baja California Sur, Mexico. Straight-line distances between major study areas and minimum/maximum distances between study sites within a study area.

\begin{tabular}{|c|c|c|c|c|c|c|}
\hline $\begin{array}{c}\text { Major Study } \\
\text { Area }\end{array}$ & $\begin{array}{l}\text { Study Site } \\
\text { Names }\end{array}$ & $\begin{array}{c}\text { Total } \\
\text { Area (ha) }\end{array}$ & $\begin{array}{c}\text { Total } \\
\text { Perimeter } \\
(\mathrm{km})\end{array}$ & $\begin{array}{c}\text { Max. } \\
\text { Distance } \\
\text { Between } \\
\text { Study Sites } \\
(\mathrm{km})\end{array}$ & $\begin{array}{c}\text { Min. } \\
\text { Distance } \\
\text { Between } \\
\text { Study Sites } \\
\quad(\mathrm{km})\end{array}$ & $\begin{array}{c}\text { Average } \\
\text { Distance } \\
\text { Between } \\
\text { Study Sites } \\
\text { (km) }\end{array}$ \\
\hline \multirow[t]{6}{*}{ La Paz } & & 40.48 & 21.04 & 19.42 & 0.91 & 5.72 \\
\hline & LP1 & 2.37 & 1.62 & & & \\
\hline & LP3 & 3.71 & 1.62 & & & \\
\hline & LP4 & 3.61 & 2.41 & & & \\
\hline & LP6 & 25.05 & 10.32 & & & \\
\hline & LP7 & 5.87 & 5.07 & & & \\
\hline \multirow[t]{3}{*}{ Magdalena Bay } & & 67.79 & 10.39 & 11.90 & 11.90 & 11.90 \\
\hline & MB1 & 25.87 & 7.10 & & & \\
\hline & MB3 & 41.91 & 3.29 & & & \\
\hline PALM & & 6.46 & 2.42 & -- & -- & -- \\
\hline \multirow[t]{6}{*}{ Mulegé } & & 8.77 & 8.53 & 31.81 & 1.83 & 8.01 \\
\hline & MU2 & 1.41 & 1.92 & & & \\
\hline & MU3 & 0.35 & 0.73 & & & \\
\hline & MU4 & 3.21 & 2.01 & & & \\
\hline & MU5 & 2.92 & 1.94 & & & \\
\hline & MU6 & 0.88 & 1.93 & & & \\
\hline \multirow[t]{4}{*}{ San Lucas } & & 4.04 & 3.30 & 1.94 & 0.95 & 0.95 \\
\hline & SL1 & 0.17 & 0.17 & & & \\
\hline & SL2 & 1.74 & 1.26 & & & \\
\hline & SL3 & 2.12 & 1.87 & & & \\
\hline
\end{tabular}




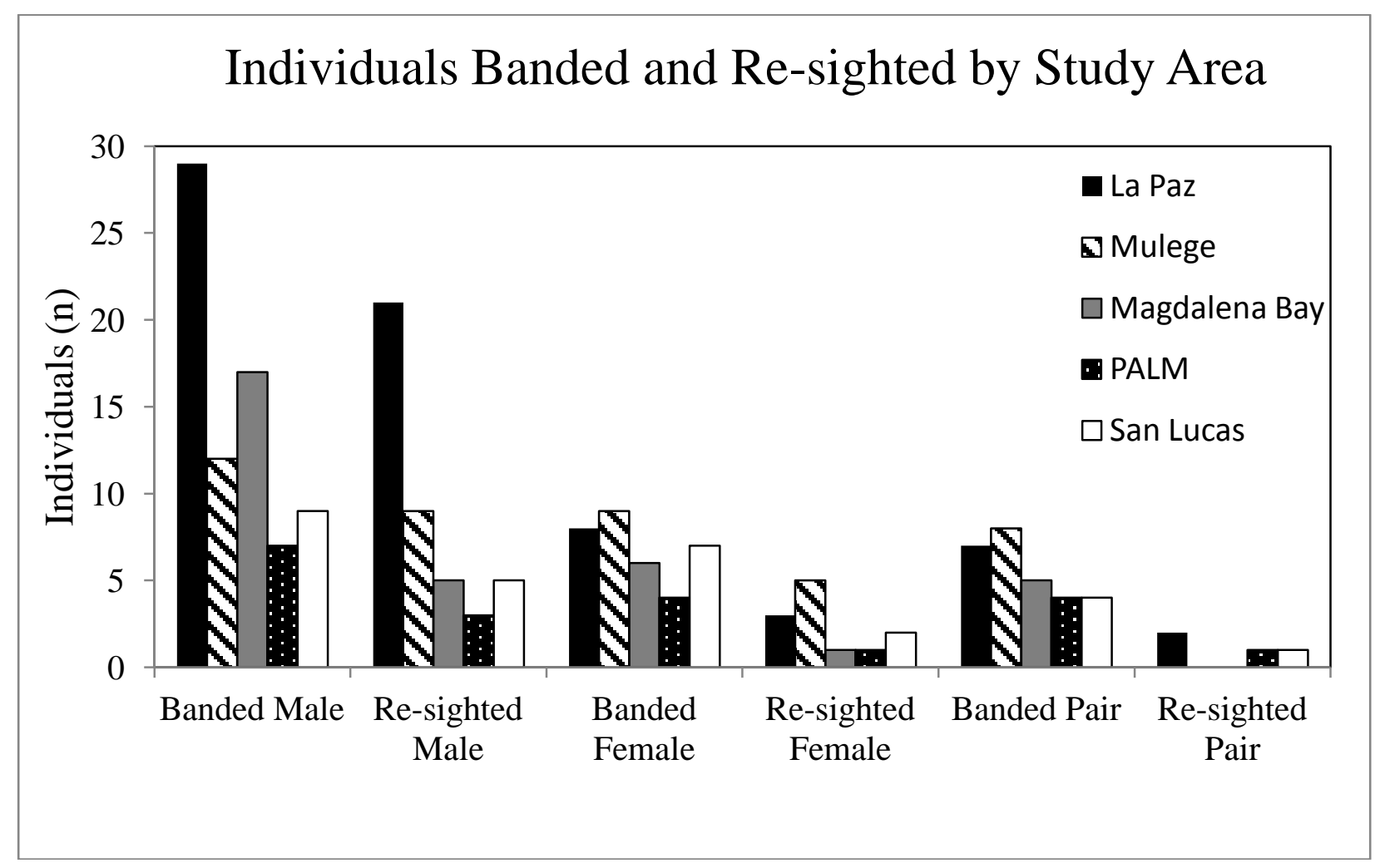

Fig. 7. Number of individuals and pairs banded (2010) and re-sighted $(2010,2011)$ in the major study areas. 
Table 2. Percent re-sights of male and female Mangrove Warblers during different periods by study area and study site in Baja California Sur, Mexico.

\begin{tabular}{|c|c|c|c|c|c|c|c|c|c|c|c|}
\hline \multirow{3}{*}{$\begin{array}{l}\text { Study } \\
\text { Area }\end{array}$} & \multirow{3}{*}{$\begin{array}{l}\text { Study } \\
\text { Site }\end{array}$} & \multicolumn{4}{|c|}{ Wintering (Nov. 2010) } & \multicolumn{4}{|c|}{ Spring (Apr. 2011) } & \multirow{2}{*}{\multicolumn{2}{|c|}{$\begin{array}{c}\text { Overall (Nov. } \\
2010 \text { and Apr. } \\
\text { 2011) } \\
\text { \% Re-sighted of } \\
\text { Total Banded } \\
\text { Population }\end{array}$}} \\
\hline & & \multicolumn{2}{|c|}{$\begin{array}{c}\text { \% Re-sighted by } \\
\text { Effort }\end{array}$} & \multicolumn{2}{|c|}{$\begin{array}{c}\% \text { Re-sighted of } \\
\text { Total Banded } \\
\text { Population }\end{array}$} & \multicolumn{2}{|c|}{$\begin{array}{c}\text { \% Re-sighted by } \\
\text { Effort }\end{array}$} & \multicolumn{2}{|c|}{$\begin{array}{c}\text { \% Re-sighted of } \\
\text { Total Banded } \\
\text { Population }\end{array}$} & & \\
\hline & & Male & Female & Male & Female & Male & Female & Male & Female & Male & Female \\
\hline \multirow[t]{6}{*}{ La Paz } & & 58.30 & 33.3 & 48.3 & 25.0 & 48.3 & 12.5 & 48.3 & 12.5 & 66.7 & 37.5 \\
\hline & LP1 & 0 & 0 & 0 & 0 & 0 & 0 & 0 & 0 & 0 & 0 \\
\hline & LP3 & 100 & - & 100 & - & 50 & - & 50 & - & 100 & - \\
\hline & LP4 & 100 & 50 & 100 & 50 & 100 & 0 & 100 & 0 & 100 & 50 \\
\hline & LP6 & 63.6 & 100 & 58.3 & 33.3 & 50 & 0 & 50 & 0 & 83.3 & 33.3 \\
\hline & LP7 & 16.7 & 0 & 10 & 0 & 30 & 50 & 30 & 50 & 40 & 50 \\
\hline \multirow[t]{3}{*}{ Mag. Bay } & & 11.8 & 0 & 11.1 & 0 & 27.8 & 28.6 & 27.8 & 28.6 & 27.8 & 28.6 \\
\hline & MB1 & 15.4 & 0 & 15.4 & 0 & 23.1 & 0 & 23.1 & 0 & 23.1 & 0 \\
\hline & MB3 & 0 & 0 & 0 & 0 & 40 & 66.7 & 40 & 66.7 & 40 & 66.7 \\
\hline PALM & & - & - & - & - & 42.9 & 25 & 42.9 & 25 & 42.9 & 25 \\
\hline \multirow[t]{6}{*}{ Mulegé } & & 40 & 12.5 & 33.3 & 11.1 & 50 & 55.6 & 50 & 55.6 & 75 & 55.6 \\
\hline & MU2 & 60 & 0 & 60 & 0 & 40 & 100 & 40 & 100 & 80 & 100 \\
\hline & MU3 & 0 & 50 & 0 & 50 & 100 & 50 & 100 & 50 & 100 & 50 \\
\hline & MU4 & 100 & 0 & 33.3 & 0 & 33.3 & 50 & 33.3 & 50 & 66.7 & 50 \\
\hline & MU5 & 0 & 0 & 0 & 0 & 50 & 0 & 50 & 0 & 50 & 0 \\
\hline & MU6 & 0 & 0 & 0 & 0 & 100 & 0 & 100 & 0 & 100 & 0 \\
\hline \multirow[t]{4}{*}{ San Lucas } & & 11.1 & 16.7 & 11.1 & 14.3 & 33.3 & 28.6 & 33.3 & 28.6 & 44.4 & 28.6 \\
\hline & SL1 & 0 & 0 & 0 & 0 & 0 & 0 & 0 & 0 & 0 & 0 \\
\hline & SL2 & 33.3 & 50 & 33.3 & 50 & 33.3 & 100 & 33.3 & 100 & 66.7 & 100 \\
\hline & SL3 & 0 & 0 & 0 & 0 & 40 & 0 & 40 & 0 & 40 & 0 \\
\hline Total & & 37.3 & 20 & 29.7 & 14.7 & 43.2 & 32.4 & 43.2 & 32.4 & 58.1 & 38.2 \\
\hline
\end{tabular}


Table 3. Population density (\# of individuals/ha) of S. p. castaneiceps across study areas and study sites, Baja California Sur, Mexico.

\begin{tabular}{|c|c|c|c|c|c|c|c|c|c|c|}
\hline \multirow[t]{2}{*}{ Study Area } & \multirow[t]{2}{*}{ Study Site } & \multicolumn{3}{|c|}{ Breeding 2010} & \multicolumn{3}{|c|}{ Wintering 2010} & \multicolumn{3}{|c|}{ Breeding 2011} \\
\hline & & Male & Female & Pairs & Male & Female & Pairs & Male & Female & Pairs \\
\hline \multirow[t]{6}{*}{ La Paz } & & 0.72 & 0.22 & 0.22 & 0.72 & 0.37 & 0.35 & 0.47 & 0.32 & 0.42 \\
\hline & LP1 & 0.42 & 0.42 & 0.42 & 1.27 & 0.84 & 0.84 & 0.42 & 0 & 0 \\
\hline & LP3 & 0.54 & 0 & 0 & 0.54 & 0.27 & 0.27 & 0.27 & 0.54 & 0.27 \\
\hline & LP4 & 1.11 & 0.55 & 0.55 & 2.77 & 1.39 & 1.39 & 1.94 & 0.83 & 0.83 \\
\hline & LP6 & 0.48 & 0.16 & 0.16 & 0.36 & 0.24 & 0.20 & 0.40 & 0.32 & 0.32 \\
\hline & LP7 & 1.70 & 0.34 & 0.34 & 0.85 & 0.17 & 0.17 & 1.02 & 0.85 & 0.85 \\
\hline \multirow[t]{3}{*}{ Magdalena Bay } & & 0.27 & 0.10 & 0.10 & 0.15 & 0.10 & 0.10 & 0.13 & 0.13 & 0.13 \\
\hline & MB1 & 0.50 & 0.15 & 0.15 & 0.35 & 0.23 & 0.23 & 0.23 & 0.19 & 0.19 \\
\hline & MB3 & 0.12 & 0.07 & 0.07 & 0.02 & 0.02 & 0.02 & 0.07 & 0.10 & 0.10 \\
\hline PALM & & 1.08 & 0.62 & 0.62 & na & na & na & 0.77 & 0.77 & 0.77 \\
\hline \multirow[t]{6}{*}{ Mulegé } & & 1.37 & 1.03 & 0.91 & 0.91 & 0.23 & 0.23 & 1.14 & 1.14 & 1.14 \\
\hline & MU2 & 3.55 & 2.13 & 2.13 & 2.13 & 0 & 0 & 2.13 & 2.84 & 2.84 \\
\hline & MU3 & 2.86 & 5.71 & 2.86 & 2.86 & 2.86 & 2.86 & 2.86 & 2.86 & 2.86 \\
\hline & MU4 & 0.93 & 0.62 & 0.62 & 0.62 & 0 & 0 & 0.93 & 0.93 & 0.93 \\
\hline & MU5 & 0.68 & 0.34 & 0.34 & 0.34 & 0 & 0 & 0.68 & 0.34 & 0.34 \\
\hline & MU6 & 1.14 & 1.14 & 1.14 & 1.14 & 1.14 & 1.14 & 1.14 & 1.14 & 1.14 \\
\hline \multirow[t]{4}{*}{ San Lucas } & & 2.23 & 1.73 & 1.73 & 1.49 & 0.99 & 0.99 & 0.99 & 0.99 & 0.99 \\
\hline & SL1 & 5.88 & 5.88 & 5.88 & 5.88 & 0 & 0 & 0 & 0 & 0 \\
\hline & SL2 & 1.72 & 1.15 & 1.15 & 1.72 & 1.72 & 1.72 & 1.15 & 1.15 & 1.15 \\
\hline & SL3 & 2.36 & 1.89 & 1.89 & 0.94 & 0.47 & 0.47 & 0.94 & 0.94 & 0.94 \\
\hline
\end{tabular}


Table 4. Repeated measures ANOVA table (using Autoregressive 1 covariance structure) comparing population densities among sex (Male, Female, Pair), season (Breeding 2010, Wintering 2010, Breeding 2011), and the interaction of sex and season.

\begin{tabular}{lrrrr}
\hline \multicolumn{5}{c}{ Type 3 Test of Fixed Effects } \\
\hline \multicolumn{1}{r}{ Effect } & Num dF & Den dF & F Value & Pr>F \\
\hline Sex & 2 & 132 & 4.27 & 0.02 \\
Season & 2 & 132 & 2.72 & 0.07 \\
Sex*Season & 4 & 132 & 0.85 & 0.50 \\
\hline
\end{tabular}




\section{Bird Density by Sex}

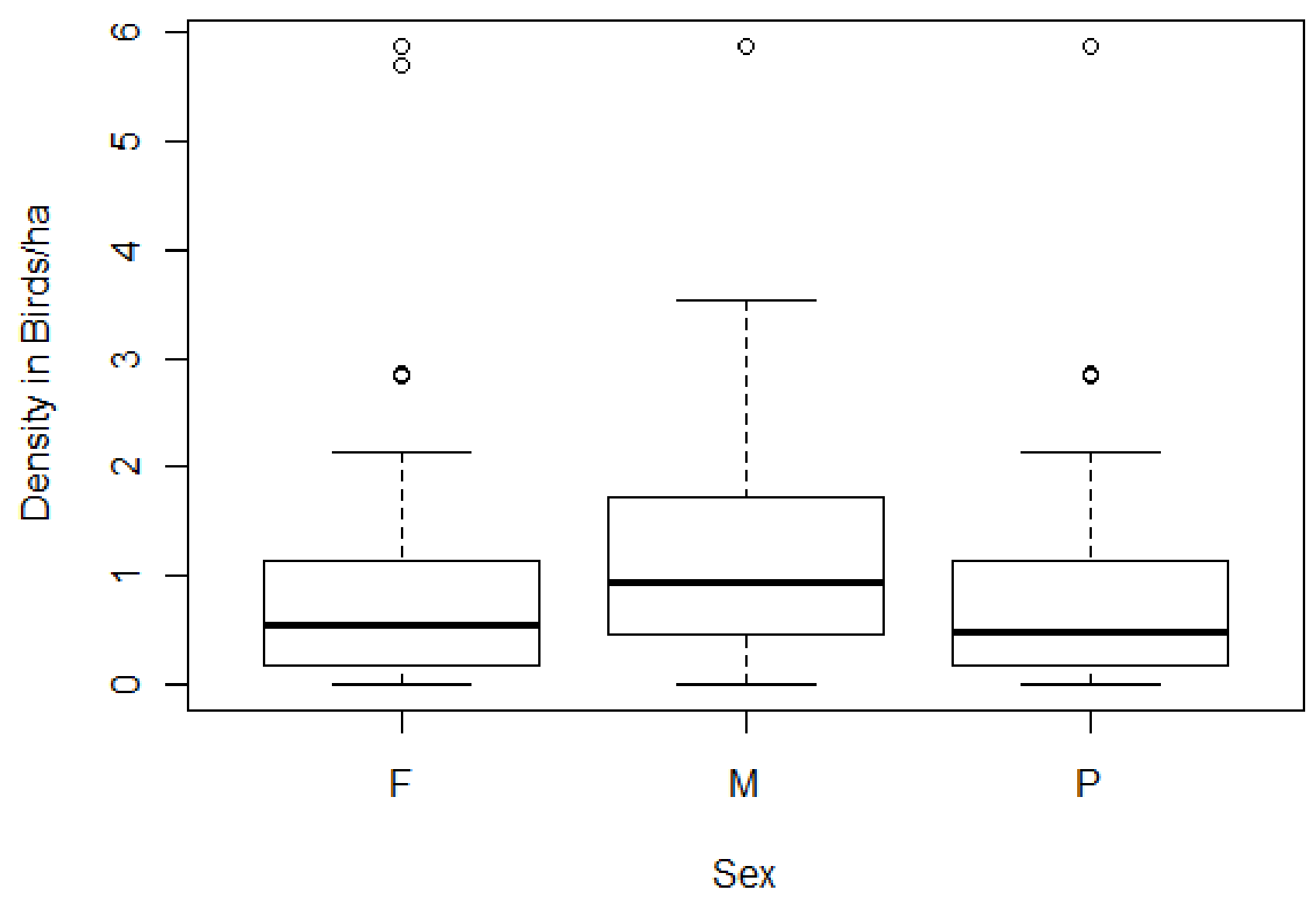

Fig. 8. Boxplots of $S$. p. castaneiceps density (birds/ha) by sex ( $\mathrm{F}=$ female, $\mathrm{M}=$ male, $\mathrm{P}=\mathrm{pair}$ ) across the combined seasons of Breeding 2010, Wintering 2010 and Breeding 2011. 


\section{Bird Density by Season}

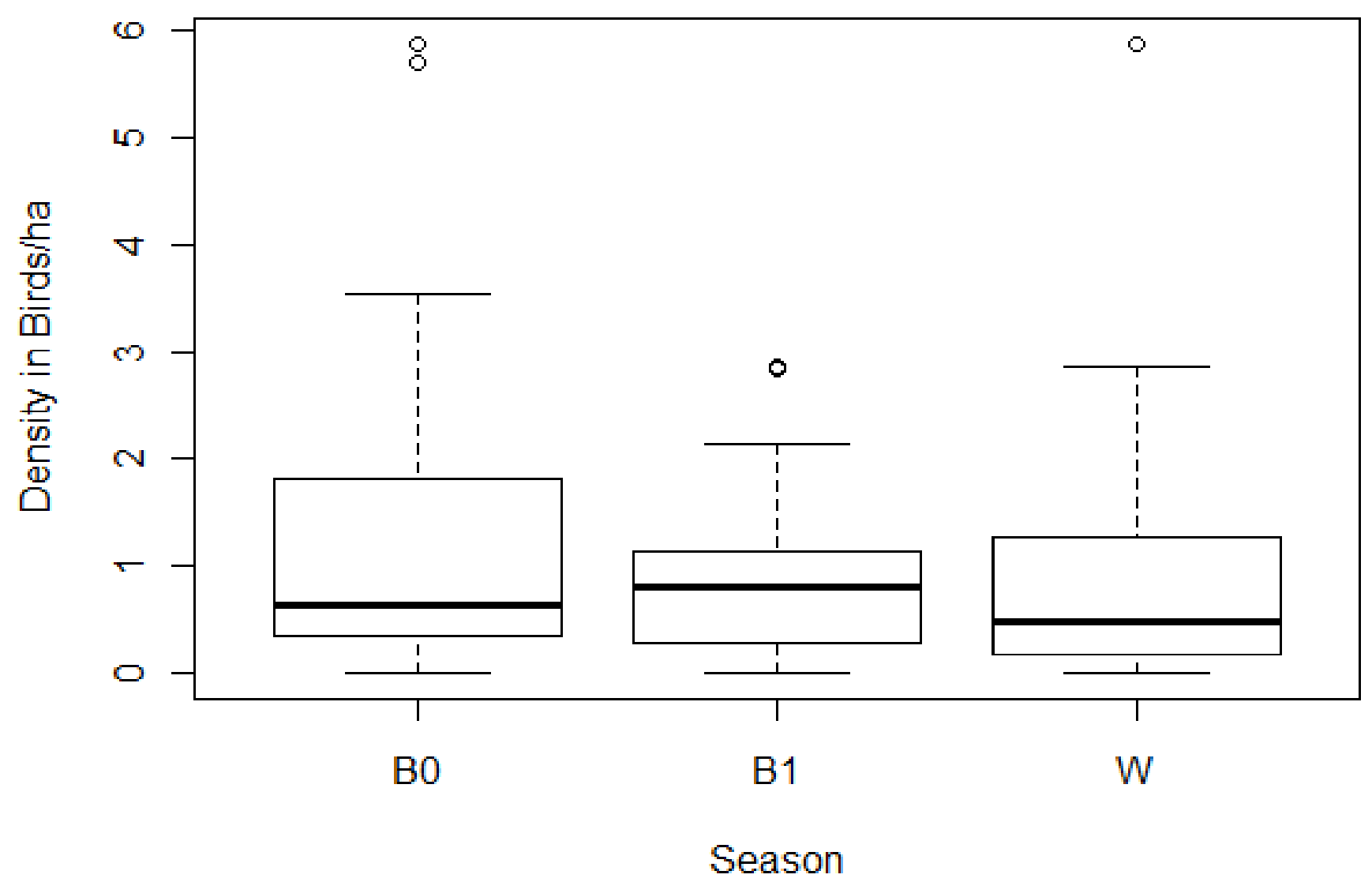

Fig. 9. Boxplots of $S$. p. castaneiceps density (birds/ha) by season (B0= Breeding 2010, B1= Breeding 2011, and $\mathrm{W}=$ Wintering 2010) across the combined sexes of males, females and pairs. 
Table 5. Territory switching in banded territorial adults observed during both re-sighting periods. All distances are straight line between an individual's observed locations. Study site refers to individual mangrove within major study area (LP, La Paz; Puerto Adolfo López Mateos, PALM; MU, Mulegé; SL, San Lucas).

\begin{tabular}{cccc}
\hline Band Combo & Sex & Study Site & Distance Moved $(\mathrm{km})$ \\
\hline BM:BBB & M & LP6 & 1.55 \\
BM:GGG & M & LP6 & 0.55 \\
BM:GBY & M & LP6 & 1.2 \\
RM:GRG & M & PALM & 0.43 \\
GM:GYB & M & MU2 & 0.91 \\
GM:GYR & M & MU2 & 0.31 \\
GM:GBR & $\mathrm{F}$ & MU2 & 0.21 \\
GM:BGR & M & MU4 & 0.03 \\
GM:BRR & M & SL3 & 0.11 \\
\hline
\end{tabular}


Table 6. Territory replacements of territorial, banded adults occurring within mangrove patches throughout the re-sighting periods. Territory vacancies refers to territories in which a previously territorial individual was not re-sighted.

\begin{tabular}{cccc}
\hline & Male & Female & Total \\
\hline Territory Vacancies & 47 & 21 & 68 \\
Filled by Banded & 7 & 1 & 8 \\
Filled by Unbanded & 25 & 13 & 38 \\
\hline
\end{tabular}

